UNIVERSIDADE DE SÃO PAULO

FACULDADE DE CIÊNCIAS FARMACÊUTICAS

Programa de pós-graduação em Farmácia

Área de Fisiopatologia e Toxicologia

\title{
Avaliação da resposta imune induzida por células dendríticas previamente ativadas por Fonsecaea pedrosoi e agonistas das vias de TLR-2 e TLR-9 na Cromoblastomicose experimental
}

\author{
Larissa Neves Monteiro Paulo
}

Orientador: Prof. Dr. Sandro Rogério de Almeida

Dissertação para obtenção do título de Mestre apresentado ao Programa de Pós-

Graduação em Farmácia, área de Fisiopatologia e Toxicologia, Faculdade de Ciências Farmacêuticas, USP. 


\title{
UNIVERSIDADE DE SÃO PAULO
}

\section{FACULDADE DE CIÊNCIAS FARMACÊUTICAS}

Programa de pós-graduação em Farmácia

Área de Fisiopatologia e Toxicologia

Avaliação da resposta imune induzida por células dendríticas previamente ativadas por Fonsecaea pedrosoi e agonistas das vias de TLR-2 e TLR-9 na

Cromoblastomicose experimental

\author{
Larissa Neves Monteiro Paulo
}

Versão corrigida da Dissertação conforme resolução CoPGr 6018.

Orientador: Prof. Dr. Sandro Rogério de Almeida 
Autorizo a reprodução e divulgação total ou parcial deste trabalho, por qualquer meio convencional ou eletronico, para fins de estudo e pesquisa, desde que citada a fonte.

Ficha Catalográfica

Elaborada pela Divisão de Biblioteca e

Documentação do Conjunto das Químicas da USP.

Bibliotecária responsável pela orientação de catalogação da publicação: Marlene Aparecida Vieira - CRB - 8/5562

Paulo, Larissa Neves Monteiro

Avaliação da resposta imune induzida por células dendríticas previamente ativadas por Fonsecaea pedrosoi e agonistas das vias de TLR-2 e TLR-9 na Cromoblastomicose experimental / Larissa Neves Monteiro Paulo. -- São Paulo, 2021.

$88 \mathrm{p}$

Dissertação (mestrado) - Faculdade de Ciências Farmacêuticas da Universidade de São Paulo. Departamento de Análises Clínicas e Toxicológicas - Programa de Pós-Graduação em Farmácia (Fisiopatologia e Toxicologia)

Orientador: Almeida, Sandro Rogério de

1. Cromoblastomicose. 2. Células Dendríticas e Migração Celular 3. TLR2. 4. Pam3CSK 4. 5. CpG-ODN. I. T. II. Almeida, Sandro Rogério de, orientador 


\title{
Larissa Neves Monteiro Paulo
}

Avaliação da resposta imune induzida por células dendríticas previamente ativadas por Fonsecaea pedrosoi e agonistas das vias de TLR-2 e TLR-9 na Cromoblastomicose experimental

\author{
Comissão Julgadora \\ da \\ Dissertação para obtenção do Título de Mestre
}

\author{
Prof. Dr. Sandro Rogério de Almeida \\ orientador/presidente \\ Profa. Dra. Eliana Barreto Bergter \\ 1o. examinador \\ Prof. Dr. Leonardo Nimrichter \\ 2o. examinador \\ Prof. Dr. Joilson de Oliveira Martins \\ 3o. examinador
}

São Paulo, 15 de Maio de 2021. 


\section{Dedicatória}

Dedico este trabalho primeiramente a Deus.

Em seguida, aos meus pais, meu marido e aos meus padrinhos.

Obrigada por toda força e ajuda! Amo vocês. 


\section{Agradecimentos}

Para realizar este trabalho e vencer os diversos obstáculos, foi necessário o apoio, a colaboração e o carinho de muitas pessoas, ou melhor: amigos.

Aos meus pais, por terem sido exemplos de vida, por me apoiarem, me ensinando sempre com todo amor e dedicação mesmo em momentos dos mais variados surtos, rs. Obrigada por todo esforço! Amo vocês.

Ao Lucas, "meu bombom" rs, por todo cuidado, carinho e compreensão, mesmo nos meus piores dias. Amo você.

Aos meus avós que já não estão mais conosco, mas me ensinaram muito do que sei hoje. Amo vocês e a saudade sempre será eterna, até algum dia!

Aos meus padrinhos que sempre investiram muito nos meus sonhos e estudos, uma base fantástica de exemplos. Sou grata por todo esforço, amo vocês!

Ao meu irmão e minha cunhada pela parceria mesmo que distante. Assim como meus sobrinhos e minha afilhada maravilhosa que teve uma madrinha super ausente nessa loucura chamada mestrado.

Ao Professor Dr. Sandro Rogério de Almeida, pela orientação e pela maravilhosa oportunidade concedida para a realização deste trabalho, bem como pela atenção, paciência e compreensão.

Aos meus amigos de laboratório que tiveram uma grande porcentagem na minha evolução não somente como pesquisadora mas também como pessoa. Muito abrigada!

Em resumo, agradeço a todos que participaram dessa experiência insana que é viver entre Itaqua e Butantã nesses 3 anos, obrigada! 
Este trabalho foi desenvolvido no Laboratório de Micologia o Departamento de Análises Clínicas e Toxicológicas da Faculdade de Farmácia da Universidade de São Paulo (USP), com auxílio financeiro da Fundação de Amparo à Pesquisa do Estado de São Paulo (FAPESP) e pelo Conselho Nacional de Desenvolvimento Científico e Tecnológico (CNPq). 


\section{RESUMO}

PAULO, L. N. M. Avaliação da resposta imune induzida por células dendríticas previamente ativadas com agonistas das vias TLR-2 e TLR-9 na Cromoblastomicose experimental. Faculdade de Ciências Farmacêuticas da Universidade de São Paulo, São Paulo, Brasil, 2018.

A cromoblastomicose é uma doença subcutânea de alta incidência, considerada um desafio por muitos profissionais, pelo fato de não possuir tratamento eficiente, nem profilático. Um dos agentes causadores dessa doença é o fungo Fonsecaea pedrosoi. Devido à cronicidade, os mecanismos de escape do fungo, componentes de parede entre outros aspectos, na infecção as taxas de cura são baixas de uma forma geral. A CBM apresenta-se na região podal, e com menor frequência em mãos e braços. Observa-se a presença de lesão papular de superfície lisa e eritematosa que gradualmente aumenta de tamanho e se torna descamativa. Os mecanismos imunológicos envolvidos na prevenção e controle da infecção por $F$. pedrosoi ainda são desconhecidos. Alguns estudos têm focado na interação fungo-hospedeiro, mostrando que a ativação da resposta imune celular do tipo Th1, é a mais importante no controle da infecção. Nos últimos anos, vários aspectos da biologia de células dendríticas foram esclarecidos e com isso, novas estratégias de tratamento e vacinação utilizando-se essas células têm sido empregadas. O racional para o uso de células dendríticas como o ponto principal para o desenvolvimento de estratégias de vacinação e imunoterapia, baseia-se nas propriedades biológicas dessas células, de possuir os processos de captura, processamento e apresentação de antígenos a linfócitos T "naive", que são altamente eficientes, resultando em uma resposta imune específica, interagindo o sistema imune inato e adaptativo. Considerando a epidemiologia da cromoblastomicose no Brasil e o desconhecimento da relação parasitohospedeiro, propomos estudar a interação de células dendríticas frente aos conídios de $F$. pedrosoi, desenvolvendo uma estratégia de vacinação baseada nas propriedades dessas células, interagidas com agonistas de via TLR e pulsadas com o fungo. Nossos experimentos mostraram que o agonista de via TLR2 (Pam3CSK4) induziu no curso da infecção, um aumento significativo de células B e células T de perfil fenotípico $\mathrm{CD}^{+}{ }^{+}$e $\mathrm{CD} 8^{+}$, assim como a citocina pró-inflamatória IL-17. Esses resultados indicam que, as células dendríticas previamente ativadas com agonitas de TLR2, podem ser promissoras no processo de vacinação na CBM experimental, porém mais estudos são necessários para uma melhor compreensão dos mecanismos efetores dessa resposta imunológica. 
Palavras Chaves: F. pedrosoi, Cromoblastomicose, Células Dendríticas e Migração Celular.

\begin{abstract}
PAULO, L. N. M. Avaliação da resposta imune induzida por células dendríticas previamente ativadas com agonistas das vias TLR-2 e TLR-9 na Cromoblastomicose experimental. Faculdade de Ciências Farmacêuticas da Universidade de São Paulo, São Paulo, Brasil, 2018.
\end{abstract}

Chromoblastomycosis is a subcutaneous disease of high incidence, considered a challenge by many professionals, due to the fact that it does not have an efficient or prophylactic treatment. One of the causative agents of this disease is the fungus Fonsecaea pedrosoi. Due to chronicity, the escape mechanisms of the fungus, wall components and other aspects, in infection the cure rates are generally low. CBM is present in the foot region, and less frequently in the hands and arms. The presence of a papular lesion with a smooth and erythematous surface is observed, which gradually increases in size and becomes scaly. The immunological mechanisms involved in the prevention and control of F. pedrosoi infection are still unknown. Some studies have focused on the fungus-host interaction, showing that the activation of the Th1-type cellular immune response is the most important in controlling infection. In recent years, several aspects of the biology of dendritic cells have been clarified and with this, new treatment and vaccination strategies using these cells have been employed. The rationale for the use of dendritic cells as the main point for the development of vaccination and immunotherapy strategies is based on the biological properties of these cells, of having the processes of capture, processing and presentation of antigens to "naive" $\mathrm{T}$ lymphocytes, which they are highly efficient, resulting in a specific immune response, interacting the innate and adaptive immune system. Considering the epidemiology of chromoblastomycosis in Brazil and the ignorance of the parasite-host relationship, we propose to study the interaction of dendritic cells against the conidia of F. pedrosoi, developing a vaccination strategy based on the properties of these cells interacted with agonists of TLR pathway and pulsed with the fungus. Our experiments showed that the TLR2 pathway agonist (Pam3CSK4) induced, in the course of infection, a significant increase in B cells and $\mathrm{T}$ cells with a phenotypic profile CD4 + and CD8 +, as well as the pro-inflammatory cytokine IL-17. 
These results indicate that dendritic cells previously activated with TLR2 agonites may present an effective immunization against murine CBM.

Keys words: $F$. pedrosoi, Chromoblastomycosis, Dendritic Cell and Cell Migration 


\section{SUMÁRIO}

1 Introdução ............................................................................................................................6

1.1. Cromoblastomicose....................................................................................................................6

1.2. Manifestações Clínicas e Epidemiologia ........................................................................7

1.3. Polimorfismo da Fonsecaea pedrosoi .........................................................................11

1.4. Fatores de virulência e melanina ......................................................................................14

1.5. Diagnóstico e tratamento......................................................................................................16

1.6. Ativação de células dendríticas e interação com linfócitos $T$....................................18

1.7. Receptores do tipo TLR (TLRs) .......................................................................................21

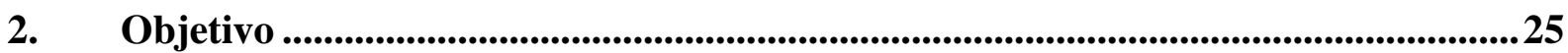

2.1. Objetivo Geral: ..........................................................................................................................25

2.2. Objetivos Específicos:..................................................................................................25

3. Material e Métodos................................................................................................................27

3.1. Animais ........................................................................................................................ 27

3.2. Fungo............................................................................................................................2

3.3. Obtenção do conídio ........................................................................................................27

3.4. Inativação pelo calor (Heat Killed/ HK) ......................................................................27

3.5. Experimentos in vitro .............................................................................................................28

3.5.1. Obtenção e caracterização de células dendríticas ..............................................28

3.6. Experimentos In Vivo ........................................................................................................28

3.6.1. Interação de DCs e $F$. pedrosoi na presença de agonistas de TLR.................28

3.6.2. Imunização com DCs pulsadas com o fungo ........................................................29

3.6.3. Imunofenotipagem do linfonodo com conídios vivos e mortos de $F$. pedrosoi por citometria de fluxo..............................................................................................................30 
3.6.4. Determinação de UFC ...................................................................................

3.6.5 Dosagem de citocinas (Elisa) ............................................................................. 31

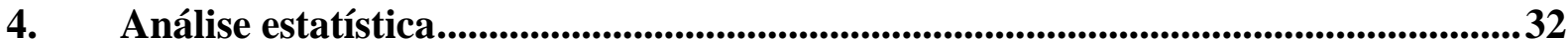

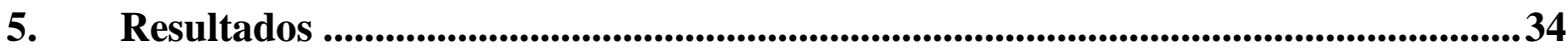

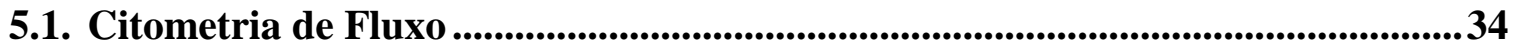

5.1.1. Caracterização de subpopulações de células $T$ nos linfonodos de camundongos infectados por 7 dias após tratamento com células dendríticas pulsadas com agonistas de TLR-2 e TLR-9. ............................................................................. 34

5.1.2. Caracterização de subpopulações de células $B$ nos linfonodos de camundongos infectados por 7 dias após tratamento com células dendríticas pulsadas com agonistas de TLR-2 e TLR-9.

5.1.3. Caracterização de moléculas de MHC-II nos linfonodos de camundongos infectados por 7 dias após tratamento com células dendríticas pulsadas com agonistas de TLR-2 e TLR-9. ................................................................................. 41

5.1.4 Caracterização de subpopulações de células $T$ nos linfonodos de camundongos infectados por 30 dias após tratamento com células dendríticas pulsadas com agonistas de TLR-2 e TLR-9.

5.1.5 Caracterização de subpopulações de células $B$ nos linfonodos de camundongos infectados por 30 dias após tratamento com células dendríticas pulsadas com agonistas de TLR-2 e TLR-9.

5.1.6 Caracterização de moléculas de MHC-II nos linfonodos de camundongos infectados por 30 dias após tratamento com células dendríticas pulsadas com

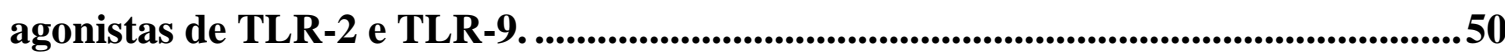

6.0 Unidades Formadoras de Colônias .......................................................................53

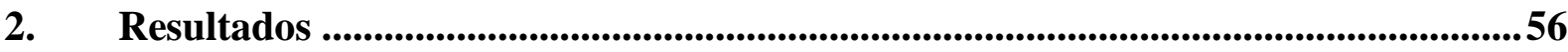

2.1. Citometria de Fluxo ...........................................................................................................55

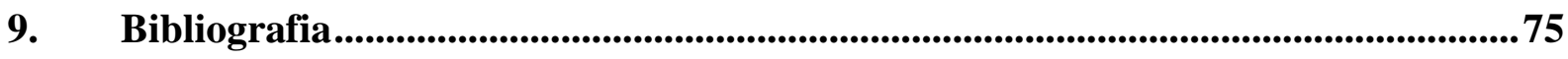




\section{ÍNDICE DE FIGURAS}

Figura 1. Macro e Micromorfologia de F. pedrosoi.

Figura 2. Distribuição geográfica mundial da cromoblastomicose de acordo com casos registrados. (QUEIROZ-TELLES, 2017).

Figura 3. Tipos de manifestações clínicas. 10

Figura 4. Tipos clínicos de lesões observadas em pacientes com cromoblastomicose...... 10

Figura 5. Micromorfologia das formas de Fonsecaea pedrosoi....................................... 13

Figura 6. Macro e ultramicrografia do Fonsecaea pedrosoi ............................................ 14

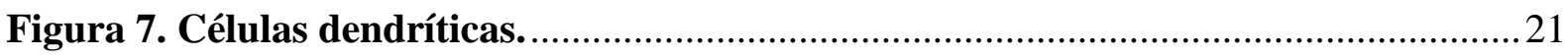

Figura 8. Vias de sinalização dos TLR-Like Receptors (TLR). .................................. 25

Figura 9. Esquema de imunização dos animais com DCs pulsadas com Fonsecaea pedrosoi.

Figura 10. Análise fenotípica de células CD3+/CD4+ CD3+/CD8+ do linfonodo obtidas em experimento in vivo.

Figura 11. Análise fenotípica de células CD3+/CD4+ do linfonodo obtidas em experimento in vivo.

Figura 12. Análise fenotípica de células CD3+/CD8+ do linfonodo obtidas em experimento in vivo.

Figura 13. Análise fenotípica de células B220+/CD19+ do linfonodo obtidas em experimento in vivo.

Figura 14. Análise fenotípica de células B220+/CD19+ do linfonodo obtidas em experimento in vivo.

Figura 15. Análise fenotípica de células MHC-II+ do linfonodo obtidas em experimento in vivo.

Figura 16. Análise fenotípica de células MHC-II+ linfonodo obtidas em experimento in vivo.

Figura 17. Análise fenotípica de células CD3+/CD4+ CD3+/CD8+ do baço obtidas em experimento in vivo. Erro! Indicador não definido.

Figura 18. Análise fenotípica de células CD3+/CD4+ CD3+/CD8+ do linfonodo obtidas em experimento in vivo. Erro! Indicador não definido.

Figura 19. Análise fenotípica de células CD19+/CD45R+ IgM+ do baço obtidas em experimento in vivo. Erro! Indicador não definido. 
Figura 20. Análise fenotípica de células CD19+/CD45R+ IgM+ do linfonodo obtidas em experimento in vivo. Erro! Indicador não definido.

Figura 21. Análise fenotípica de células CD3+/CD4+ CD3+/CD8+ do linfonodo obtidas em experimento in vivo. 466

Figura 22. Análise fenotípica de células CD3+/CD4+ do linfonodo obtidas em experimento in vivo.

Figura 23. Análise fenotípica de células CD3+/CD8+ do linfonodo obtidas em experimento in vivo.

Figura 24. Análise fenotípica de células B220+/CD19+ e IgM do linfonodo obtidas em experimento in vivo.

Figura 25. Análise fenotípica de células B220+/CD19+ do linfonodo obtidas em experimento in vivo.

Figura 26. Análise fenotípica de células MHC-II+ do linfonodo obtidas em experimento in vivo. 52

Figura 27. Análise fenotípica de células MHC-II+ do linfonodo obtidas em experimento in vivo.

Figura 28. Análise fenotípica de células CD3+/CD4+ CD3+/CD8+ do baço obtidas em experimento in vivo. Erro! Indicador não definido.

Figura 29. Análise fenotípica de células CD3+/CD4+ CD3+/CD8+ do linfonodo obtidas em experimento in vivo. Erro! Indicador não definido.

Figura 30. Unidades formadoras de colônias do baço de camundongos BALB/c infectados com $10^{6}$ de conídios de $F$. pedrosoi na presença ou ausência de PAM3CSK4 e CpG, por 7 dias.

Figura 31. Unidades formadoras de colônias do fígado de camundongos BALB/c infectados com $10^{6}$ de conídios de $F$. pedrosoi na presença ou ausência de PAM3CSK4 e CpG, por 7 dias 54

Figura 32. Análise das citocinas: IFN- $\gamma$ obtidas em experimento in vivo. 66

Figura 33. Análise das citocinas: IL-6 obtidas em experimento in vivo. 67

Figura 34. Análise das citocinas: IL-10 obtidas em experimento in vivo. 68

Figura 35. Análise das citocinas: IL-17 obtidas em experimento in vivo.

Figura 36. Unidades formadoras de colônias do fígado e baço de camundongos BALB/c infectados com $1 \times 10^{7}$ de conídios de $F$. pedrosoi na presença ou ausência de PAM3CSK4, por 7 dias. Erro! Indicador não definido. 
ÍNDICE DE TABELAS

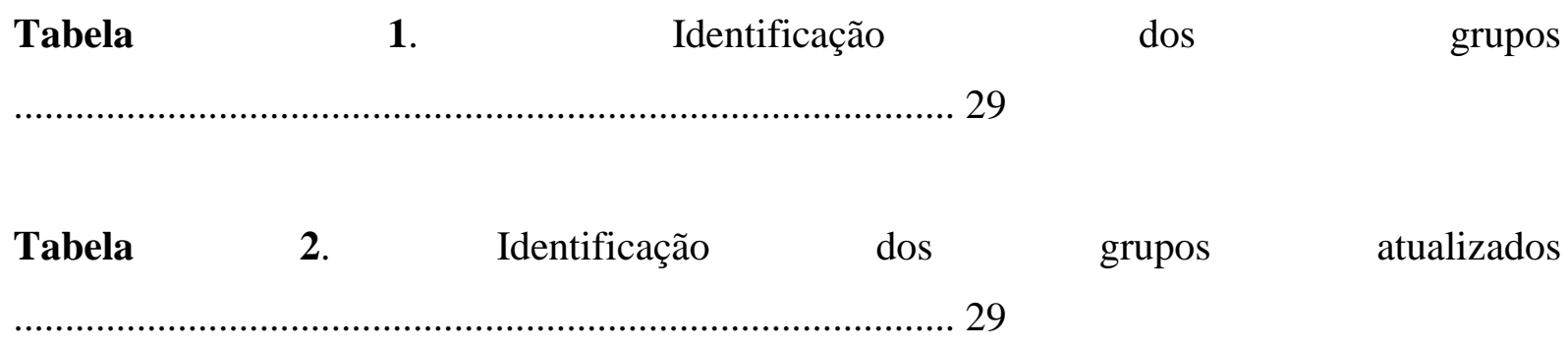




\section{LISTA DE ABREVIATURAS}

- $\quad{ }^{\circ} \mathrm{C}$ - Graus Celsius

- APC - Antigen presenting cell (Célula apresentadora de antígeno)

- $\mathrm{BD}$ - Meio Batata Dextrose

- BMDCs - Células Dendríticas Derivadas da Medula Óssea

- $\mathrm{CBM}-$ Cromoblastomicose

- $\mathrm{CFU}$ - colony-forming units

- CEUA - Comissão de Ética em Experimentação Animal da Faculdade de Ciências Farmacêuticas

- DC - Células dendríticas

- ELISA - Ensaio de Ligação Imunoenzimático

- FACS - Fluorescent Activated Cell Sorting (Separação de célula pela atividade de fluorescência)

- F.pedrosoi.-Fonsecaea pedrosoi

- GM-CSF - Fator Estimulador de Colônias de Macrófagos e Granulócitos

- HK - Heat Killed

- IFN- $\gamma-$ Interferon gama

- $\quad \mathrm{IL}$ - Interleucina

- i.p. - Intraperitoneal

- Ig - imunoglobulina

- LPS - Lipopolissacarídeos

- $\mathrm{MHC}$ - Major histocompatibility complex

- MyD88 - Myeloid differentiation primary response gene 88

- $\quad \mathrm{NF}-\kappa \mathrm{B}-$ Fator Nuclear kappa B

- PAMPs - Padrões Moleculares Associados a Patógenos

- $\quad$ PBS - Tampão Fosfato-salino

- PFA - Paraformaldeído

- $\mathrm{pH}$ - Potencial Hidrogeniônico

- PRRs - Receptores de Reconhecimento de Padrões

- $\quad r p m$ - Rotações por Minuto

- $\quad$ RPMI - Meio Roswell Park Memorial Institute

- $\mathrm{SFB}$ - Soro Fetal Bovino 
- SPF - Specific Pathogen Free ( Padrão sanitário livre de patógenos específicos)

- $\quad$ Syk - Tirosina-quinase Esplênica

- TCR -Receptor de células T

- $\quad$ Th - Linfócitos T Auxiliares

- Th1 - T "helper" 1

- $\quad$ Th2 $-\mathrm{T}$ "helper" 2

- $\mathrm{TCD} 4^{+}-$Linfócito T "helper" CD4 ${ }^{+}$

- $\quad \mathrm{TCD}^{+}-$Linfócito T "helper" $\mathrm{CD} 8^{+}$

- TGF $\beta$ - Fator de transformação do crescimento

- TLRs - Receptores do Tipo TLR

- TNF- $\alpha-$ Fator de Necrose Tumoral alfa 


\section{Introdução}

\subsection{Cromoblastomicose}

A cromoblastomicose caracteriza-se por ser uma micose de tecidos cutâneos e subcutâneos, causada por via traumática por meio de penetração do agente etiológico. As espécies capazes de causar esse tipo de micose pertencem à família Dematiceae que possui um grande número de espécies e são caracterizadas por apresentarem pigmentos em sua parede celular, possuindo um espectro de cor entre o marrom-claro e preto (Figura 1) (LACAZ, et al. 2002). O pigmento, geralmente é constituído por melanina (dihidroxinaftaleno - melanina), antioxidante que confere resistência à uma lise fagocitária (SAN BLAS G, 1982).

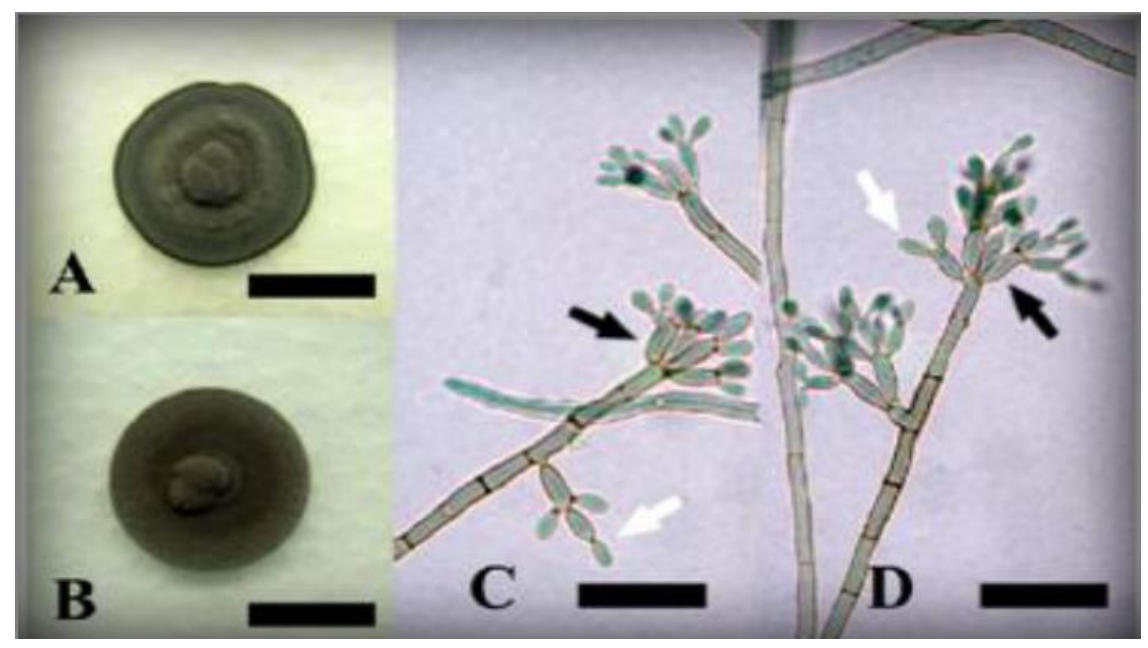

Figura 1. Macro e Micromorfologia de $\boldsymbol{F}$. pedrosoi. Aspectos macroscópicos da cultura do fungo (A e B), apresentam coloração escura e aveludada. Micromorfologia possui hifas que apresentam conidióforos terminais (seta preta) e conídios (seta branca) (C e D) (SALGADO et al., 2004).

Os agentes mais frequentes dessa micose são: Fonsecaea pedrosoi, Fonsecaea compacta, Cladophilalophora (Cladosporium) carionii, Rhinocladiella aquaspersa e Phialophora verrucosa. São fungos pleomórficos, apresentam-se de forma micelial em vida saprofítica e muriforme, vida parasitária caracterizada por células escleróticas (LACAZ et al., 2002).

No ano de 1914, o alemão Max Rudolph, em Minas Gerais publicou os primeiros casos de cromobastomicose do estado e de Goiás. Além de detalhar a doença, antes conhecida como figueira, também obteve em cultivo hifas de um fungo negro em diferentes pacientes, porém em seu trabalho Rudolph não descreveu esse parasita nas 
lesões (CASTRO, 1998). Depois de um ano, Lane e Medlar, em publicações diferentes, descreveram o primeiro caso na América do Norte com etiologia atribuída a Phialophora verrucosa. Desde que a cromoblastomicose foi descoberta várias terminologias foram usadas para definir a doença, são elas: figueira, formigueiro, dermatite verrucosa cromomicótica, doença de Pedroso, doença de Fonseca, doença de Carrion, entre outras.

O termo final, cromoblastomicose foi citado por Terra et al., em 1922, atualmente esse é o termo indicado pelo "Internacional Society of Human and Animal Micology" (ISHAM) (ODDS F.C et al., 1992).

\subsection{Manifestações Clínicas e Epidemiologia}

A cromoblastomicose acomete todos os continentes, porém possui uma incidência maior em regiões tropicais e subtropicais (Figura 2), com agentes etiológicos ubíquos na natureza que fazem parte do solo, da água e da matéria orgânica em decomposição sem exigências especificas como o pH (LACAZ, 2002).

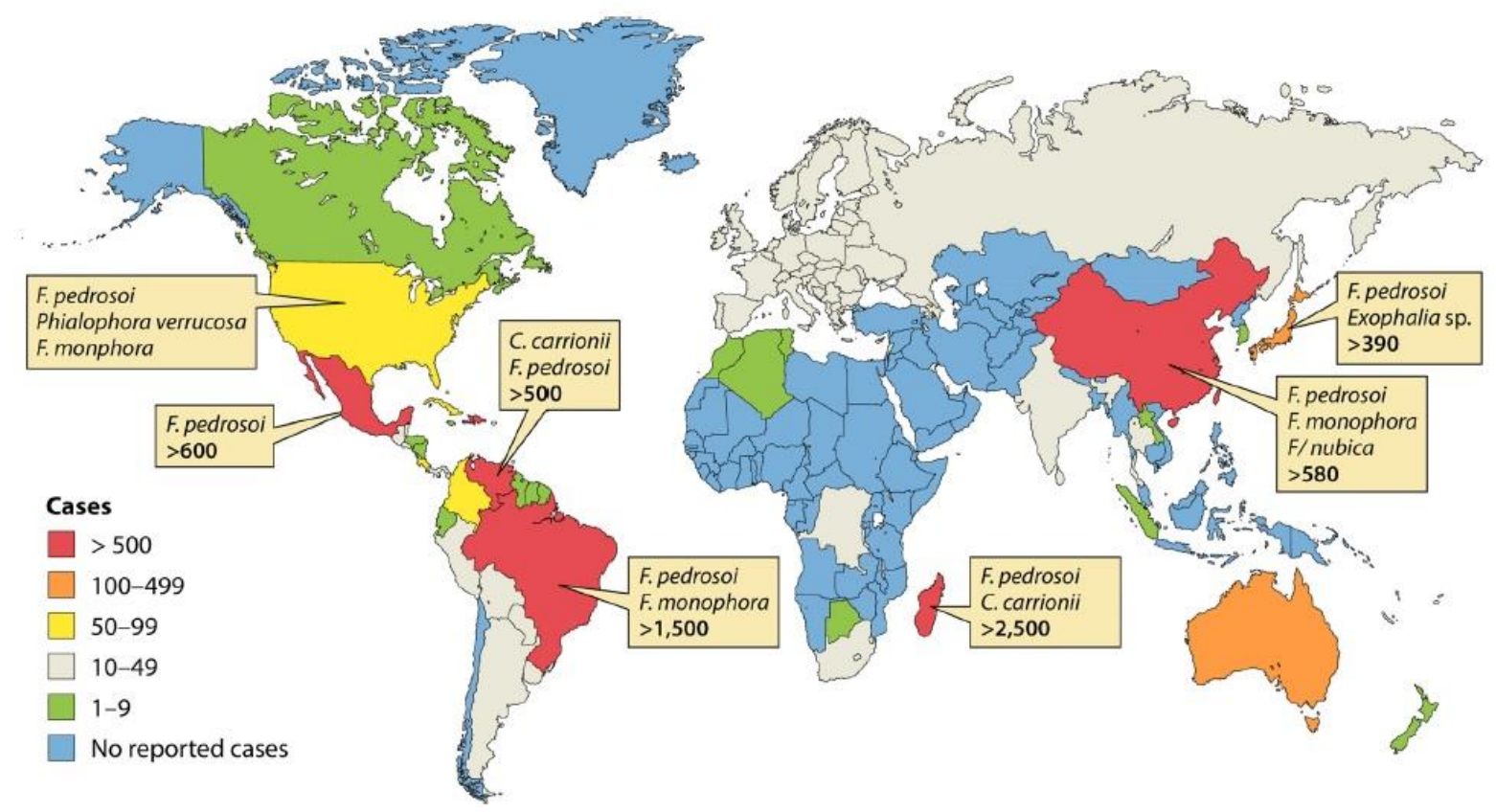

Figura 2. Distribuição geográfica mundial da cromoblastomicose de acordo com casos registrados. (QUEIROZ-TELLES, 2017).

Esse tipo de fungo, não possui habitat específico, estão dispersos na natureza. Algumas espécies como $P$. verrucosa e $F$. pedrosoi já foram observadas em polpa de madeira, plantas mortas, restos de árvores e espinhos. 
No Brasil, a cromoblastomicose já foi descrita em quase todos os estados, principalmente na Região Amazônica, São Paulo, Rio de Janeiro, Minas Gerais e Rio Grande do Sul.

A doença, como citado acima, é causada por vários fungos demáceos, as manifestações clínicas são semelhantes, sendo uma infecção fúngica primária, ocorre com maior frequência em imunocompetentes (DE HOOG et al., 2004; BONIFAZ et al., 2010). A manifestação clínica é predominante em adultos na faixa etária entre 40-70 anos, com prevalência em gênero masculino, possivelmente devido a razões ocupacionais, visto que os homens afetados pela doença são, em sua maioria, trabalhadores rurais e, devido a isso, expostos com maior frequência à potenciais fontes de contaminação (SILVA et. al., 1999; BONIFAZ et. al., 2001).

As lesões se localizam principalmente na região podal, pernas, nádegas e já foram descritas com menos frequências nas mãos, braços, região articular, nasal e em outras partes do corpo (BITTENCOURT et al., 1994).

No início é possível observar no local da penetração, uma lesão papular de superfície lisa e eritematosa, que aumenta e se transforma em nódulos superficiais, podendo se expandir lateralmente formando placas. Nódulos e placas podem originar lesão tumoral ou papilomatosa, com o aspecto parecido com o de uma couve-flor (CASTRO, 1998; LACAZ, 2002).

As lesões da cromoblastomicose inicialmente podem evoluir para três distintos tipos: nodular, placa e verruciforme. Boop (1959) classifica as manifestações cutâneas da doença em duas formas: placa e nodular, acrescentando subtipo na forma nodular (sarcodino) e subtipos em forma de placa (tuberculóide, maduromicosiforme, psoriasiforme). É importante ressaltar que a mesma lesão pode apresentar mais de uma forma de apresentação, e pode ser seguida de uma infecção secundária e/ou edema.

Em sua fase inicial, a lesão é oligossintomática, não causando interferência no estado geral do paciente. Em sua fase crônica os sintomas apresentados geralmente são: prurido, dor local, principalmente quando há uma infecção bacteriana secundária, fibrose (lesão extensa e de longa duração), linfoedema crônico com aspecto elefantiásico, que pode gerar comprometimento permanente no trabalho (Figura 3 e 4) (SILVA et al., 1995; TELLES, 1999).

As complicações mais frequentes são infecções secundárias e linfo edema, não sendo raro o caso de amputação de membro acometido. Já houve relatos de casos 
severos da cromoblastomicose evoluindo para um carcinoma espinocelular (FORSTER et al., 1987).

Clinicamente algumas formas da doença podem ser confundidas com várias outras doenças como: sífilis terciária, micetoma, leishmaniose e esporotricose. No entanto, em meio de cultura é de fácil reconhecimento e define diagnóstico (LACAZ, 2002).

O principal meio de disseminação dos agentes é por meio de acometimento de áreas cutâneas adjacentes, por contiguidade. Pode ocorre autoinoculação, e em menor frequência pode ocorrer por via linfática.

Ainda que existam registros na literatura da disseminação sistêmica de agentes etiológicos da cromoblastomicose, majoritariamente em tecidos cerebrais, são casos raros e classificados como de feohifomicose (NOBREGA et. al., 2003; SURASH et. al., 2005; TAKEI, 2007; DE AZEVEDO et. al., 2015; KHAN et. al., 2015).

Mesmo que a doença não seja letal, ela compromete a forma de vida de pacientes inoculados, por gerar deformação, dores e prurido nos membros acometidos, em casos a amputação se faz necessária. 

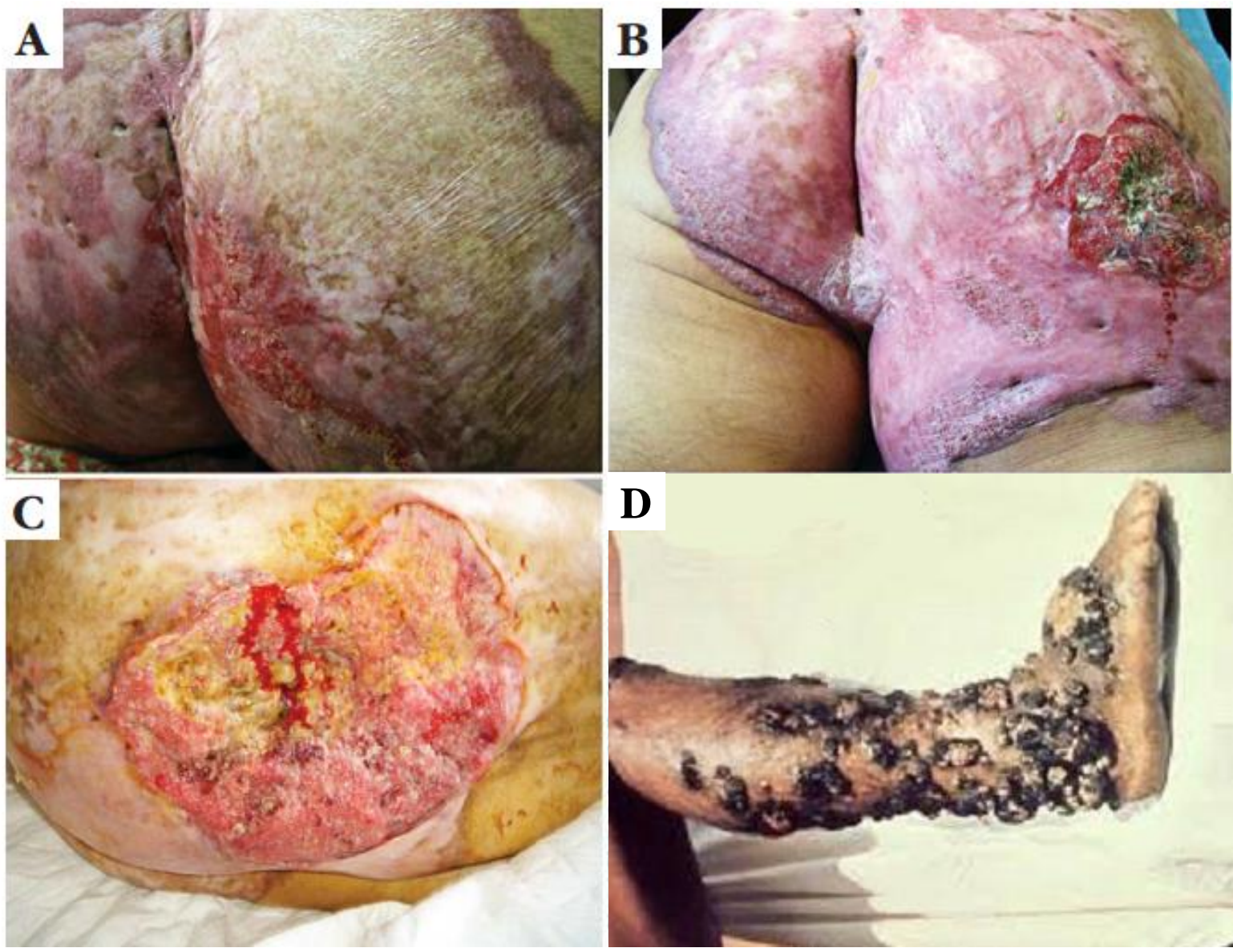

Figura 3. Tipos de manifestações clínicas. A, placa verrucosa com áreas de queratose, ulceração e atrofia; B, úlceras crônicas com reação inflamatória; $\mathrm{C}$, tecido de granulação exuberante onde o carcinoma se desenvolveu; D, lesões vegetantes. Adaptado de TORRES et al., 2010.

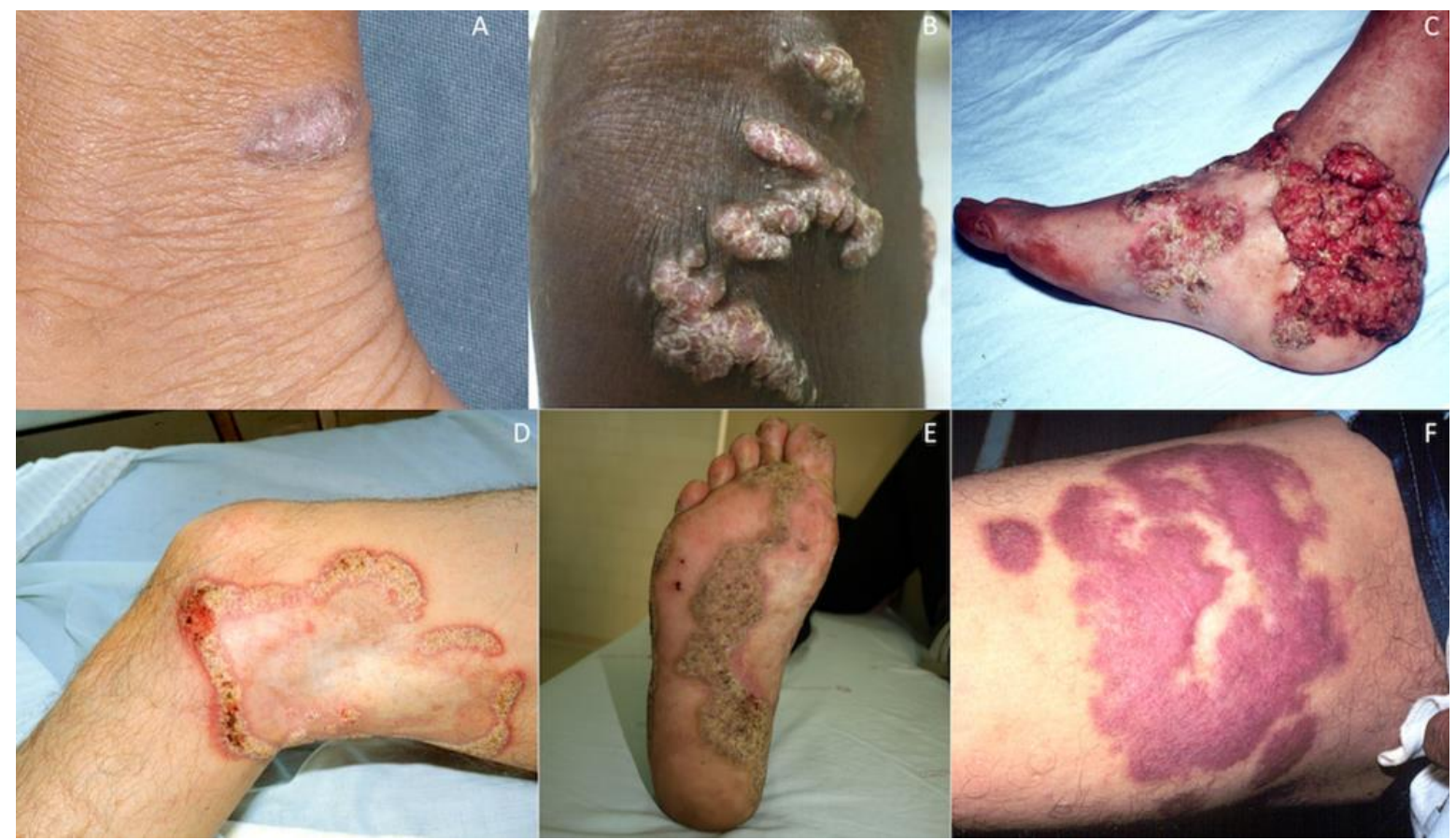

Figura 4. Tipos clínicos de lesões observadas em pacientes com cromoblastomicose. A, lesão inicial com duração de 3 meses na perna. B, lesões nodulares confluentes no joelho. C, lesão tumoral (tipo 
couve-flor) na parte posterior do pé. $\mathrm{D}$, lesão cicatricial com verruga mostrando contornos serpiginosos e verrucosos. E, lesão verrucosa hiperqueratótica na sola do pé. F, placa violácea macia lesão na raiz da coxa. Fonte: QUEIROZ-TELLES et al., 2017.

\subsection{Polimorfismo da Fonsecaea pedrosoi}

Em 300 mil espécies fúngicas já descritas, sendo que é estimado um valor de até 5,1 milhões de espécies existentes, uma margem de 150 a 200 são considerados patogênicos (KERRIDGE, 1993; CHAKRABARTI, 2005; O’BRIEN et. al., 2005).

Os fungos sendo patogênicos ou não, podem apresentar duas morfologias básicas: esférica e tubular (Figura 5 e 6). Em relação a isso, todos os fungos se enquadrariam no grupo dos pleomórficos, no entanto o que caracteriza um fungo pleomórfico seria a capacidade de crescer como hifas e micélios, e alguns deles podem também se desenvolver em esporos, assim sendo, apresentando de 3 a 4 tipos de desenvolvimento (GOW,1994).

Sabe-se que a capacidade do fungo transitar entre essas morfologias é o que determina a sua virulência, tendo em vista que essas mudanças de desenvolvimento acarretam várias outras mudanças, tais como: composição de parede, lipídios de membrana, sinalização intracelular e expressão gênica que de alguma maneira contribuem para sua permanência no hospedeiro.

Diferentes formas do desenvolvimento da infecção por C. albicans, induzem perfis diferentes de resposta imune, enquanto a interação dos fagócitos com leveduras induzia a produção de IL-12, citocina importante na polarização de uma resposta Th1, a fase filamentosa desse fungo modula uma indução de um perfil Th2, marcado pela presença de altos níveis de IL-10 e IL-4 e baixa produção de IFN- $\gamma$, sendo esta uma citocina fundamental na formação de uma resposta imune responsiva frente à candidíase (ROMANI et. al., 1997; CHIANI et. al., 2000; D'OSTIANI, 2000; VAN DER GRAAF et. al., 2005).

Outro fungo cuja virulência é dependente da transição entre variados tipos morfológico é o fungo $F$. pedrosoi que, juntamente aos demais agentes causadores da CBM, é um ascomiceto polimórfico pertencente à família Herpotrichiellaceae (KRZYŚCIAK et. al., 2014). O papel das diferentes formas de apresentação do F. pedrosoi na infecção e no estabelecimento da doença ainda é pouco esclarecido, especialmente quando se trata das formas saprofíticas, conídios e hifas (SALGADO, 2010). Essas formas são encontradas no ambiente e, quando rompem a barreira protetora do hospedeiro, passam por um processo de 
transformação em células muriformes (Figura 4C), que são intensamente melanizadas medindo 4-12 $\mu \mathrm{m}$ de diâmetro, arredondadas, semelhantes às leveduras, e que são consideradas as responsáveis pela cronicidade da CBM (BONIFAZ et. al., 2001; SANTOS et. al., 2007). As células muriformes presentes nos hospedeiros da CBM, são encontradas dentro de células gigantes multinucleadas ou em microabscessos do tecido epitelial e derme (ESTERRE \& RICHARD-BLUM, 2002; ESTERRE \& QUEIROZ-TELLES, 2006; QUEIROZ-TELLES et. al., 2009; SALGADO, 2010). Em vários momentos, hifas são localizadas nas camadas mais superficiais da lesão, onde acredita-se que estão associadas a um papel de autoinoculação do fungo no hospedeiro, assim como o seu retorno à natureza, o que nos faz acreditar que essas hifas foram formadas pela reversão de células muriformes (BAYLES, 1986; ROSEN \& OVERHOLT, 1996; LEE et. al., 1998; BONIFAZ et. al., 2001). Embora as células muriformes sejam consideradas as formas patogênicas na CBM, a patogenia das hifas é mais descrita no contexto da feohifomicose, uma doença marcada, em sua maioria, pela disseminação de hifas de alguns agentes que causam a cromoblastomicose, e que geralmente apresenta um desfecho grave para o hospedeiro, por comprometerem tecidos cerebrais (NOBREGA et. al., 2003; SURASH et. al., 2005; TAKEI, 2007; KHAN et. al., 2015). Além disso, assim como as células muriformes, e diferentemente de conídios, hifas apresentam intensa atividade de ecto-fosfatases, que são enzimas importantes para a nutrição, proliferação, adesão, virulência e infecção fúngica (KNEIPP et. al., 2003, 2004; FREITAS-MESQUITA \& MEYER-FERNANDES, 2014). 

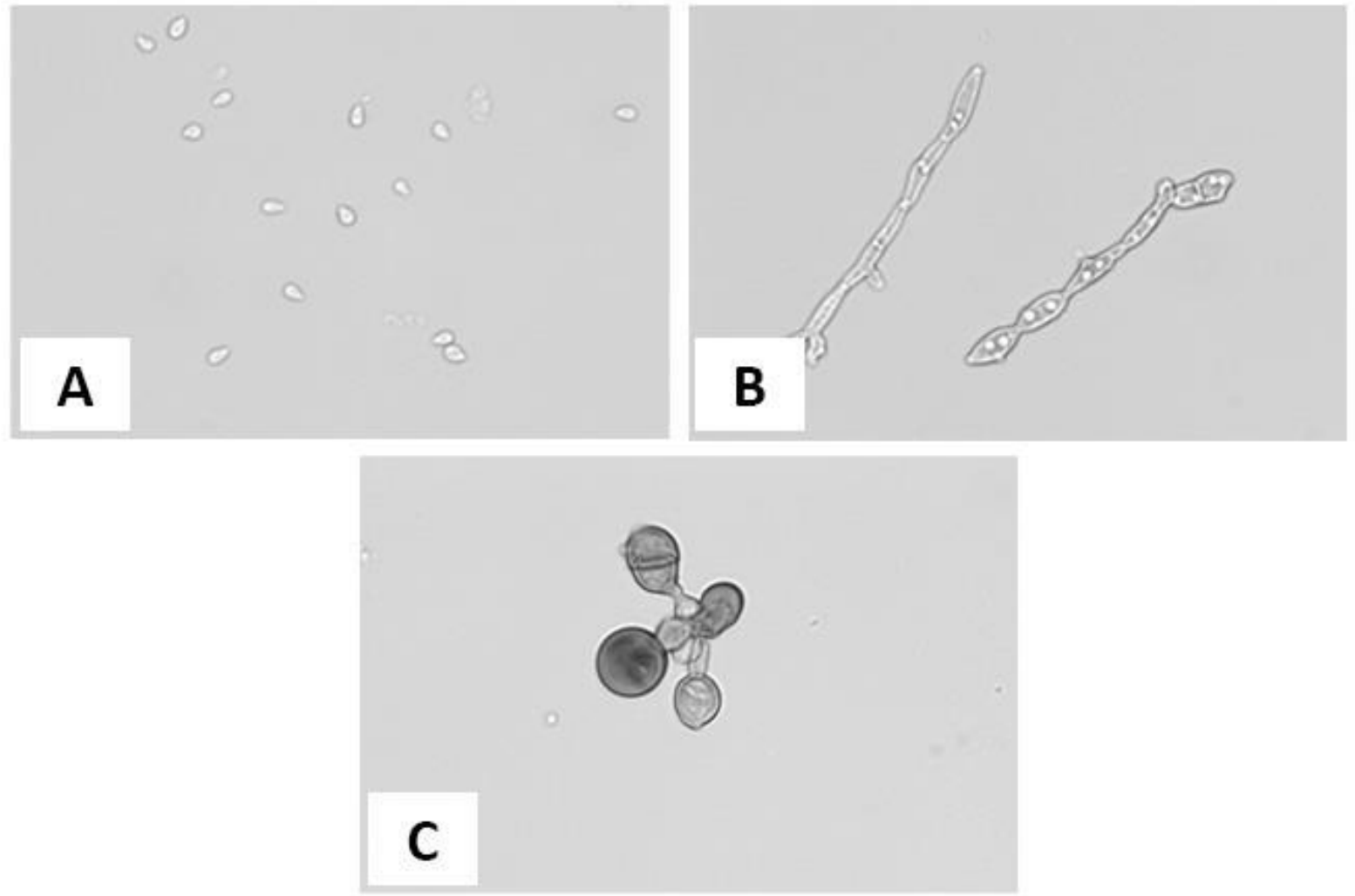

Figura 5. Micromorfologia das formas de Fonsecaea pedrosoi. Formas saprofíticas - conídios e fragmentos de hifas (A e B) - parasitárias, células muriformes (C), de Fonsecaea pedrosoi sob magnificação de 400x. Fonte: CASTRO, 2016. 


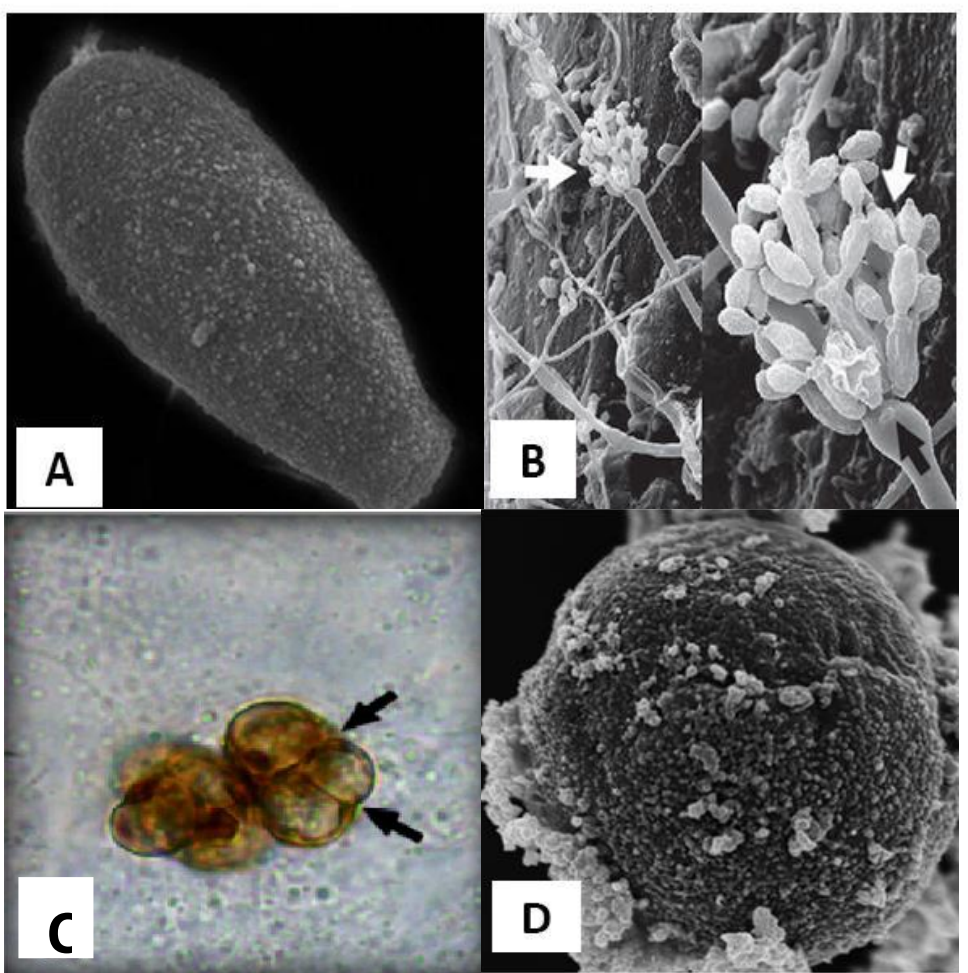

Figura 6. Macro e ultramicrografia do Fonsecaea pedrosoi. Ultramicrografia de varredura de conídios isolados (A) ou associados a hifas em espinho de Mimosa pudica (B); e células muriformes (C e D) corpos escleróticos de F. pedrosoi. Forma patogênica. Modificado de SALGADO et. al., 2004; FRANZEN et. al., 2006.

A sobrevivência de um fungo demáceo no hospedeiro humano, no qual é considerado um habitat hostil, é favorecida pela presença de melanina na parede celular, pelos lipídios das diversas estruturas celulares e pela termotolerância à $37^{\circ} \mathrm{C}$ (RIBEIRO et

al., 2006).

\subsection{Fatores de virulência e melanina}

A suscetibilidade do hospedeiro à infecção não depende unicamente das condições fisiológicas e imunológicas do mesmo, e isso se torna mais evidente quando a existência de patógenos primários são consideradas, capazes de causar doenças em qualquer comportamento imunológico, isto é, imunocompetentes ou imunocomprometidos. Na interação parasita-hospedeiro, a sobrevivência do parasita é coordenada de fatores de virulência (mecanismos, ações ou produção de certos componentes), que possibilitam a entrada, a replicação e a permanecia no hospedeiro (CROSS, 2008). 
Alguns fatores de virulência já foram descritos para os fungos, e costumam provê-los das seguintes capacidades: (I) colonização (por meio da expressão de adesinas ou formação de biofilmes); (II) evasão da resposta do hospedeiro (por meio da transição morfológica, produção de agentes antioxidantes); (III) imunossupressão (por meio da expressão de moléculas anti-inflamatórias); (IV) parasitismo intracelular, no caso de parasitas intracelulares (produção de agentes tamponantes ou inibidores da acidificação lisossomal); (V) obtenção de nutrientes (por meio da secreção de moléculas como fosfolipases que degradam lipídios auxiliando no fornecimento de carbono) (KERRIDGE, 1993; CASADEVALL \& PIROFSKI, 2009; DJORDJEVIC, 2010).

$\mathrm{O} F$. pedrosoi é um patógeno primário e, assim como outros agentes de micoses subcutâneas, necessita de apenas uma lesão na barreira protetora, como a pele, para iniciar o processo infeccioso, ainda pouco compreendido (DE HOOG et. al., 2004; BONIFAZ et. al., 2010). Entretanto, já foram descritas até o momento uma variedade de potenciais fatores de virulência do $F$. pedrosoi, sendo que alguns são compartilhados por outros fungos patogênicos: (I) produção de ecto-fosfatases e fosfolipases, que estariam envolvidas no processo de adesão do fungo ao hospedeiro (KNEIPP et. al., 2003, 2004; COLLOPY-JUNIOR, 2006); (II) crescimento em temperatura corporal humana $\left(37^{\circ} \mathrm{C}\right.$ ) (ALVIANO et. al., 1992); (III) tolerância ao pH ácido (ALVIANO et. al., 1992); (IV) presença de $\alpha$-glucana (NÓBREGA et. al., 2010); (V) capacidade de produzir e secretar melanina, depositando-a em sua parede celular (ALVIANO et. al., 1991; BOCCA et. al., 2006; FRANZEN et. al., 2008).

A melanina é um pigmento ubíquo na natureza e encontrado em todos os reinos biológicos, apresentando uma ampla variedade de funções, como defesa contra o estresse ambiental protegendo da radiação ultravioleta, radiações ionizantes e agentes oxidantes (EISENMAN \& CASADEVALL, 2012). Embora sua produção derive de vias metabólicas e seus componentes associados, que podem ser diferentes entre o organismo de origem, o que se leva a considerar a melanina como um grupo amplo de substâncias, esses pigmentos compartilham determinadas propriedades: (I) são polímeros de alta massa molecular; (II) exibem alta termoestabilidade (III); e são carregadas negativamente (WHITE, 1958; EISENMAN \& CASADEVALL, 2012). Embora fungos como $C$. neoformans sejam capazes de sintetizar melanina externamente à célula fúngica, por meio de vesículas secretadas que possuem atividade de lacase, a síntese de melanina nos fungos costuma ocorrer em organelas citoplasmáticas especializadas denominadas melanossomos (EISENMAN \& CASADEVALL, 2012). A 
melanogênese é iniciada com a formação de uma matriz fibrilar, que passa por um processo de espessamento e escurecimento em decorrência à formação de depósitos de melanina. Ao final do desenvolvimento do grânulo, ocorre o transporte até sua fusão com a membrana celular, liberando seu conteúdo entre a mesma e a parede do fungo, promovendo a formação de múltiplas camadas concêntricas de melanina na parede celular (FRANZEN et. al., 2008).

Considerando que tais camadas não são sólidas, mas exibem um aspecto granular, provavelmente associado à deposição da melanina na forma de pacotes, como sugerido por Franzen e colaboradores (2006, 2008), entende-se que a melanina se acomoda na parede por meio de ligações cruzadas com outros componentes de parede celular, como a quitina.

A integração do pigmento com a parede celular e seus componentes provavelmente estão relacionadas à redução dos poros da parede celular fúngica. Posteriormente, a redução dos poros proporcionada pela melanização da célula, junto às propriedades absortivas apresentadas pela melanina, poderiam ser os mecanismos pelos quais células melanizadas de Fonsecaea pedrosoi apresentam maior resistência a drogas antifúngicas em comparação ao fungo deficiente desse polímero (EISENMAN et. al., 2005; CUNHA, 2008). Outras funções estão associadas à melanina do Fonsecaea pedrosoi que a tornam um fator de virulência, incluindo: a inibição da fagocitose (CUNHA et. al., 2005); o mascaramento de componentes antigênicos, capazes de induzir a produção de anticorpos com efeito microbicida ao fungo (NIMRICHTER et. al., 2004, 2005); a resistência à eliminação por macrófagos (CUNHA et. al., 2005) e a proteção contra burst oxidativo (BOCCA et. al., 2006; CUNHA et. al., 2010; ZHANG et. al., 2012).

\subsection{Diagnóstico e tratamento}

O diagnóstico é realizado pelo exame direto com material retirado das lesões, principalmente de pontos negros ao longo da lesão, clarificados com $\mathrm{KOH} 10 \%$ onde é possível observar corpos muriformes que são patognomônico da doença.

Essas células apresentam- se de forma arredondada ou elípticas, medindo de $4 \mu \mathrm{m}$ a $12 \mu \mathrm{m}$ de diâmetro, com coloração marrom e membrana bem nítida de duplo contorno (LACAZ, 2002). 
O diagnóstico completa pelo isolamento do fungo em meio Agar- Sabouraud, mantido em temperatura ambiente. As colônias começam a aparecer após 7 dias de cultivo, apresentando uma cor escura, aveludada, com centros elevados, onde apenas a análise macroscópica não identifica a espécie, já que todos os gêneros da cromoblastomicose apresentam-se de forma semelhante. A identificação do gênero, então se dá a partir de uma análise micro morfológica de conidióforos e conidiogênese. O predomínio da morfologia identifica a espécie isolada, na qual a mais frequente no Brasil é o $F$. pedrosoi, um fungo pleomórfico, que significa exatamente a sua capacidade de apresentar mais de um tipo de conidióforo (LACAZ, 2002).

O exame histopatológico é recomendado para confirmar casos de falso-negativos. Nos tecidos acometidos observa-se que os agentes da cromoblastomicose provocam resposta inflamatória de padrão misto, de origem supurativa e granulomatosa (SALFEDER, 1990).

$\mathrm{Na}$ epiderme as principais características são: hiperplasia pseudo-epiteliomatosas ou acantose, podendo ocorrer hiperceratose ou abscessos. $\mathrm{Na}$ derme o infiltrado contém nódulos granulomatosos confluentes, composto por células epitelióides células gigantes ou corpos estranhos. Os granulomas podem conter micro abscessos com infiltração de neutrófilos e restos celulares (TIBIRIÇÁ, 1939; PURIM, 1991; URIBE et al., 1989).

Os testes imunológicos não são empregados rotineiramente como método de diagnóstico, porque a detecção de fungo pelo exame direto, histopatológico e isolamento em cultivo são mais vantajosos (QUEIROZ-TELLES et al., 2016).

A cromoblastomicose é um desafio terapêutico enfrentado pelos profissionais da saúde e pelos pacientes. Diversos métodos e substâncias já foram utilizados, mas os resultados, raramente possuem consistência suficiente que justifique sua utilização em larga escala (QUEIROZ-TELLES, 1997; CASTRO, 1998). Segundo Castro (1992) a existência de várias modalidades terapêuticas é a prova de que nenhuma delas apresenta eficácia suficiente para ser qualificada como método de eleição. A doença possui formas de tratamento, sendo elas: quimioterápica e físicas tais como cirurgia convencional, cirurgia a laser, termo terapia e crioterapia (BONIFAZ et al., 1997, POIRRIEZ et al., 2000, CASTRO et al., 2003). Entre eles, o tratamento cirúrgico parece ser a escolha mais eficaz para controlar a cromoblastomicose. A cirurgia, a eletrodissecação e a crio cirurgia são mais efetivas nos estágios iniciais (LUPI et al., 2005). O calor local pode reduzir substancialmente a extensão das lesões e a necessidade de cirurgias extensas. Uma terapia bem-sucedida de infecção por $F$. 
pedrosoi foi observada através da manutenção da temperatura da superfície a $46^{\circ} \mathrm{C}$ durante pelo menos $5 \mathrm{~h}$ diariamente durante 2 meses e do uso de um laser de dióxido de carbono (HIRA et al., 2002). Membros incapacitados ou deformados podem necessitar de amputação (ELGART, 1996). Geralmente os tratamentos são usados simultaneamente, justamente pela dificuldade encontrada para o tratamento da doença, principalmente quando o diagnóstico não é no início da manifestação. Os antifúngicos que mostram uma melhor resposta são Itraconazol (200 a 400mg/dia) e Terbinafina (500 a $1000 \mathrm{mg} / \mathrm{dia})$, usados de 6 a 12 meses.

\subsection{Ativação de células dendríticas e interação com linfócitos $\mathbf{T}$}

Os linfócitos $\mathrm{TCD}^{+}$, também conhecidos como linfócitos Th ("helper") ou T auxiliares, são células centrais do sistema imunológico adaptativo, responsáveis pela organização de uma resposta imunológica. A ativação correta de T naive é um evento essencial para o desenvolvimento de uma resposta imune eficaz no combate aos patógenos, e importante para evitar o surgimento de doenças autoimunes. Esse processo acontece em um microambiente apropriado fornecido pelos órgãos linfoides periféricos que são necessários para uma interação correta entre diversos tipos celulares e moléculas do sistema imune (HUANG e GERMAN, 2004). Nesses locais a ativação, proliferação clonal e diferenciação dos linfócitos $\mathrm{T}$ em células efetoras ocorre quando essas células reconhecem antígenos por meio de uma interação de TCR com os peptídeos apresentados por moléculas de MHC. Os linfócitos TCD4 ${ }^{+}$reconhecem peptídeos antigênicos associados a moléculas do MHC de classe II, presente na superfície de células apresentadoras de antígeno (APCs) (Figura 7), como macrófagos, células dendríticas e linfócitos $\mathrm{B}$, enquanto os linfócitos $\mathrm{TCD} 8^{+}$reconhecem antígenos associados a moléculas de MHC de classe I, presente em todas células nucleadas do organismo. Para que haja uma ativação correta e completa dos linfócitos TCD4 ${ }^{+}$, estas células precisam de sinais coestimuladores vindos das APC's no momento do reconhecimento. Quando ocorre o primeiro sinal, e consecutivamente não ocorre o 
segundo, a célula se torna anérgica, ou seja, irresponsível levando a morte, em alguns casos (GIMMI et al., 1993).

O sinal coestimulador, descrito como segundo sinal é a interação de CD28 presente constitutivamente em linfócitos T e o CD80/CD86 de expressão indutível na superfície das APC's, a expressão de CD80 e CD86 é positiva e rapidamente modulada após a estimulação com ligantes de TLR's (GOSH et al., 1998)

O amadurecimento completo de macrófagos e células dendríticas são fundamentais para aumentar a sua capacidade de apresentação de antígeno, expressão de moléculas coestimuladora e alterar o perfil de produção de molécula solúvel. Um dos sinais mais importantes para maturação das APC's ocorre por meio de estimulação de receptores, denominados PRR (Pattern-recognition receptors) (GOSH et al., 1998, IWASAKIE MEDZHITOV,2004) que reconhecem padrões moleculares que são frequentemente associados aos patógenos (Phatogen associated molecular patternPAMPS) (KOPP e MEDZHITOV,2003).

Macrófago e células dendríticas, atuam como uma ponte entre sistema imune inato e sistema imune adaptativo, funcionando como sensores microbianos, sinais de perigo e realizando a apresentação para o sistema imune adquirido.

Como citado acima, a ativação correta de células T naive requer uma sinalização por meio de TCR e células CD28 (LENSCHOW et al., 1996; LIU e JANEWAY, 1992). Essas exigências são cumpridas somente por células dendríticas maduras expostas ao ligante TLRs que sinalizam para que ocorra um aumento na expressão de moléculas de MHC e de moléculas coestimuladora (BANCHEREAU e STEINMAN, 1998).

A migração das APCs para o linfonodo drenante e subsequente ativação de células $\mathrm{T}$ naive garante que a resposta imune seja montada somente contra antígenos derivados de patógenos, tendo em vista que a interação DC imadura e células T virgens gera um estado de tolerância ou indução de células T reguladoras (STEINMAN et al., 2003).

Tradicionalmente, as células dendríticas são classificadas de acordo com a localização anatômica, a expressão de moléculas de superfície e a função no sistema imunológico. A importância dos grupos de células dendríticas tem sido atribuída à existência de diferentes atuações na resposta imunológica que envolve a produção de citocinas e quimiocinas, receptores de fagocitose de antígenos e receptores de reconhecimento de microrganismos (LIPSCOMB E MASTEN, 2002). As células dendríticas formam grupos heterogêneos com localização em vários órgãos, em sítio de 
exposição a antígenos, como mucosas e tecidos periféricos, são agrupadas em: células dendríticas convencionais (cDCs) e células dendríticas plasmocitóide (pDCs). Os precursores têm origem na medula óssea e migram para os tecidos, como por exemplo, a pele (denominadas células de Langherans), sangue, linfa, sistema respiratório e gastrointestinal. As células dendríticas imaturas possuem intensa atividade endocítica, podendo capturar vários tipos de antígenos e patógenos, células infectadas e mortas (TASSANEETRITHEP, BURGESS et al., 2003), são fagócitos ineficientes nos tecidos periféricos, apresentam baixa expressão de moléculas coestimuladoras e moléculas de MHC de classe I e classe II (GUERMONPREZ et al., 2002; STEINMAN, 2003).

Os linfócitos são como reguladores de resposta imune a antígenos proteicos, e servem como células efetoras para eliminação de antígenos. Os receptores de célula T (TCR) reconhecem apenas antígenos peptídicos ligados a proteínas codificadas por genes do sistema de histocompatibilidade (MHC), expressas pelas apresentadoras de antígenos (JANKOVIC et al., 2001). Para que as respostas por linfócitos T aconteçam, é necessária a interação com células apresentadoras de antígenos (APC), proliferem e assim se tornem células efetoras. As células dendríticas, macrófagos e linfócitos B são células apresentadoras de antígeno capazes de processar e apresentar antígenos aos linfócitos T (UNANUE; ALLEN, 1987).

Os padrões de citocinas encontrados em pacientes com CBM na forma grave da doença (placa verrucosa) possui a produção de IL- 10 e TNF $\alpha$, associados a baixos níveis de IFN $-\gamma$ e a proliferação de linfócitos. Porém pacientes com grau leve da doença apresentam altos níveis séricos de IFN $-\gamma$ e linfócitos, e baixos níveis de IL-10, sugerindo que a atividade da IL-10 estava contribuindo negativamente para a atividade do macrófago. Os dados nos possibilitam a entender que conforme há um aumento na produção de IFN $\gamma$, principal citocina ativadora de macrófago, melhor é o quadro clínico do paciente (GIMENES et al., 2005). 


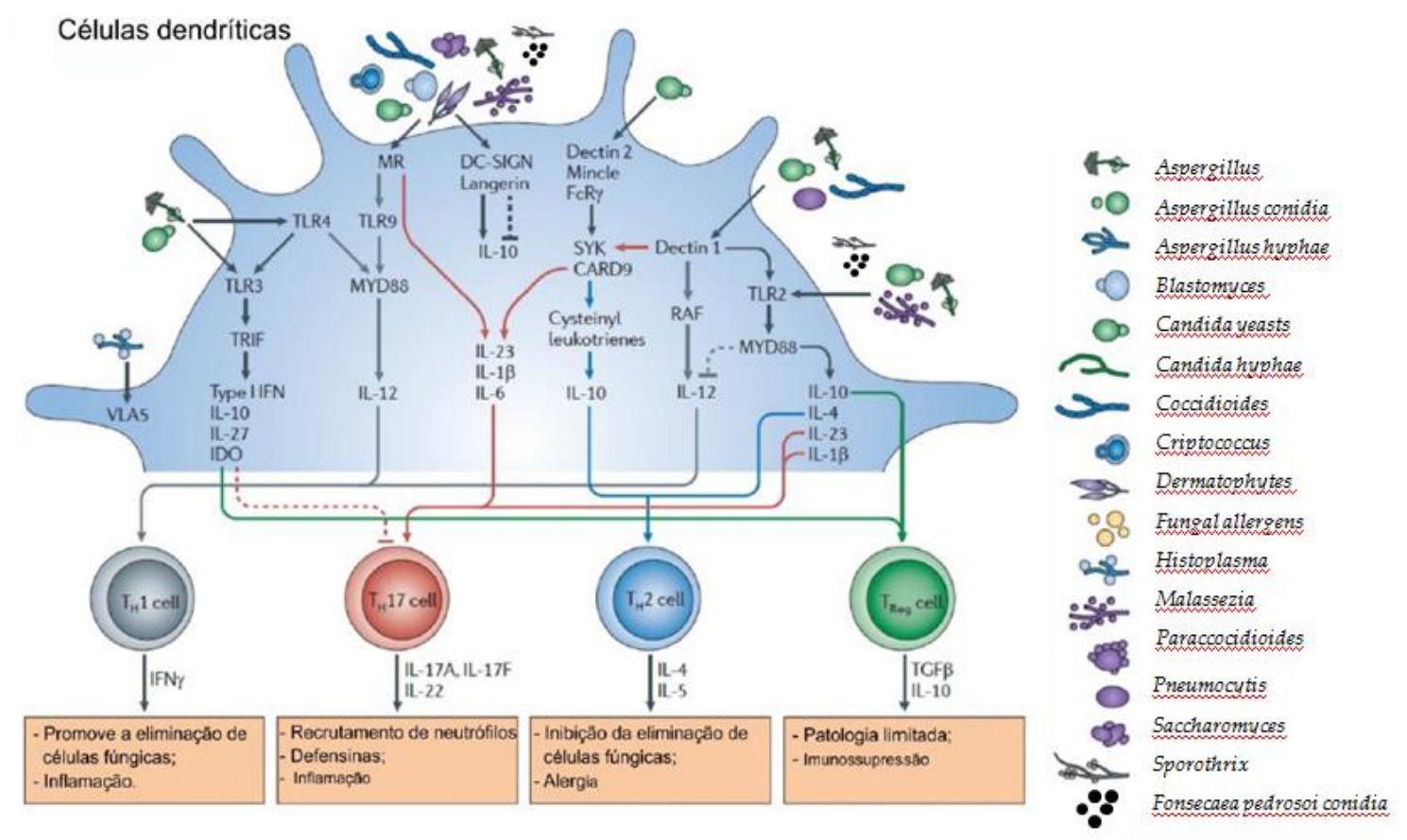

Figura 7. Células dendríticas. Adaptado de Romani, 2011.

\subsection{Receptores do tipo TLR (TLRs)}

Como dito antes, a ativação das APCs pelo patógeno ocorre por diversos mecanismos, podendo envolver diferentes receptores denominados PRRs (Figura 8)(Pattern-recognition receptors).

A família TLR foi a primeira família a ser identificada, possuindo uma ampla diversidade de membros (somente em humanos já foram descritos 11), situados tanto em compartimentos endossomais quanto na superfície celular (BOURGEOIS \& KUCHLER, 2012). No tocante à imunidade contra fungos, dentre os membros desta família, os receptores TLR2, TLR4 e TLR9 apresentam papel de destaque, mediando o reconhecimento de componentes fúngicos como zimosan, fosfolipomananas, mananas o-ligadas e DNA fúngico. Quando ativados, sinalizam normalmente via MyD88, promovendo a liberação de citocinas pró-inflamatórias, mas são incapazes de induzir fagocitose. A deficiência de receptores dessa família já foi associada a um aumento na susceptibilidade do hospedeiro à aspergilose e candidíase (ROMANI, 2004, 2011; FREEMAN \& GRINSTEIN, 2014). 
O envolvimento do TLR na imunidade inata foi primeiramente descrito na mosca Drosophila melanogaster. O gene para o receptor TLR foi descoberto em meados dos anos 80 por Eric Wieschaus e Cristiane Nüsslein-Volhard, que ganharam o prêmio Nobel de Medicina e Fisiologia em 1995. Eles descreveram o TLR como um receptor do tipo transmembrânico necessário para estabelecer a polaridade dorsoventral correta e desenvolvimento embrionário adequado desse mesmo inseto. No ano de 1996, Lemaitre e Hoffman observaram que os insetos com mutação nesse receptor eram susceptíveis às infecções pelo fungo Aspergillus fumigatus, uma vez que as mutações nesse gene bloqueavam a indução no peptídeo anti-microbiano Drosomicina, em resposta a infecções fúngicas (Lemaitre et al., 1996).

Posteriormente, Charles Janeway e Ruslan Medzhitov observaram a presença desse receptor também no genoma humano, determinando-os como TLR-like Receptors (TLRs). Esses receptores foram descritos em componentes celulares da imunidade inata, e quando estimulados pelo respectivo ligante, induzem a produção de citocinas e quimiocinas pró-inflamatórias, além de aumentar a expressão de moléculas coestimuladoras por essas células (MEDZHITOV et al., 1997).

Estudos mostram que tanto camundongos quanto humanos possuem receptores semelhantes aos receptores do tipo TLR, cada relacionado ao reconhecimento de um padrão molecular associado à patógenos (PAMPs).

Atualmente 12 membros da família TLR foram identificados em mamíferos, sendo que camundongos não possuem TLRs do tipo 8 e 10, e o genoma humano não apresenta os TLRs 11 e 12 (BEUTLER, 2009; MEDZHITOV, 2007). Os TLRs são glicoproteínas transmembrânicas, caracterizadas estruturalmente pela presença de um domínio extracelular N-terminal rico em repetições leucina (leucine-rich repeat - LRR).

Outra família de PRRs, conhecida como CLR, apresenta um papel fundamental no reconhecimento e extermínio de infecções fúngicas. Possuem alguns receptores de grande relevância na interação fungo-hospedeiro, como Mincle, DC-SIGN, receptor de manose, Dectina-1 e Dectina-2.

A Dectina-1 consta até o momento como o único receptor de $\beta$-glucana da família do CLR, carboidrato encontrado na parede fúngica, e é o mais intensamente estudado e caracterizado, possuindo deficiência genética desse receptor, o hospedeiro está muito mais susceptível às doenças fúngicas, dado que sua ativação está associada à secreção de importantes quimiocinas e citocinas pró-inflamatórias com ação na imunidade inata e adaptativa. Inclusive, já foi demonstrado que a atividade fungicida de 
neutrófilos é influenciada pelo acionamento da dectina-1. A Dectina-2, mais recentemente descrita, tem se mostrado como outro receptor de grande importância, através do reconhecimento de estruturas com alto teor de manose, idêntica à dectina-1 e outros CLRs, é promotor de fagocitose e sinaliza via Syk/CARD9 para uma ativação do

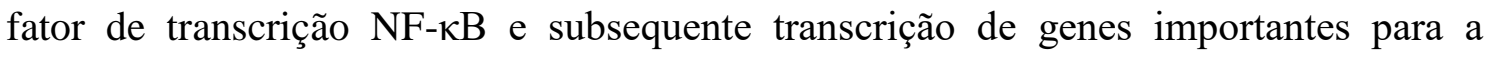
resposta imune (ROMANI, 2004, 2011; KENNEDY et. al., 2007).

Assim sendo, recentemente, Wüthrichc e colaboradores (2015) demonstraram que receptores Dectina-1 e Dectina-2 estão envolvidos no reconhecimento de $F$. pedrosoi, sendo que este último participa na polarização de uma resposta Th17 que é, por outro lado, suprimida por meio do reconhecimento do fungo via Mincle. Um estudo anterior associa este receptor também à inibição de uma resposta Th1, por meio do bloqueio da síntese da citocina IL-12 (WEVERS et. al., 2014). Sousa e colaboradores (2011) sugeriram que a falta da coestimulação de PRRs no reconhecimento de conídios de $F$. pedrosoi é um fator chave na cronicidade da cromoblastomicose, uma vez que observaram que o fornecimento de agonistas para TLR2 (PAM3CSK4), TLR4 (LPS) ou TLR7 (imiquimod) permite que as células passem a apresentar uma secreção robusta da citocina pró-inflamatória TNF- $\alpha$, apontada como importante na resposta imune durante a CBM.

Sabe-se que a espécie $F$. pedrosoi é capaz de ativar sistema complemento podendo mediar quimiotaxia (TORINUKI et al. 1984). Alguns estudos vêm mostrando a interação parasito-hospedeiro evidenciando predominantemente a resposta imune celular, com ativação e macrófagos gerando fagocitose, entretanto raramente observa-se a morte dessas células fúngicas.

Rozental et al. 1994, demonstraram que o $F$. pedrosoi foi capaz não só de sobreviver, como também de se proliferar no interior de macrófagos peritoneais murinos, ou seja, quando ativadas, essas células possuem ação fungistática e não fungicida.

Após o reconhecimento de agentes infecciosos pelos TLRs, estes receptores passam por mudanças conformacionais permitindo o recrutamento de moléculas adaptadoras. São elas: Fator 88 de diferenciação mielóide (MyD88), proteína adaptadora de MyD88 (MAL/TIRAP), domínio TIR (TRIF/ TICAM-1) e a molécula adaptadora de TRIF (TRAM) (TAKEUCHI \& AKIRA, 2010). O tipo de sinalização depende de diferentes combinações de moléculas adaptadoras. A sinalização intracelular está dividida em 2 vias e depende inicialmente do adaptador usado: Via dependente de MyD88 ou Via 
dependente de TRIF. Com exceção de TLR-3, todos os membros usam a via MyD88 para ativação do fator de transcrição NF-kB (fator nuclear kB) e das MAPKs (proteínas quinases ativadas por mitogênese) para a indução de genes pró-inflamatórios (PANDEY et al., 2015).

Em modelos murinos de doenças infecciosas, quando há um erro na sinalização por MyD88, ocorre uma diminuição da indução da resposta imune inata e adaptativa, aumentando a sensibilidade do hospedeiro à infecção.

Por meio de estudos recentes, verificou-se a importância do receptor TLR-2, pois a sua ausência foi relacionada a um aumento da susceptibilidade à candidíase disseminada em modelos murinos devido a uma diminuição na secreção de TNF- $\alpha$ e MIP-2 e no recrutamento de neutrófilos (BELLOCCHIO et al., 2004). Em contraste, outros estudos mostraram que camundongos TLR-2-/- são mais resistentes a candidíase sistêmica, mostrando um aumento na quimiotaxia e secreção de IFN- $\gamma$, e uma baixa na secreção de IL-10, bem como, no número de células Treg CD4+ CD25+. Interessantemente, o recrutamento de monócitos aumentou em camundongos TLR-2-/-, sugerindo um aumento da atividade anti-Candida nesses animais (NETEA et al., 2004). A imunossupressão em camundongos TLR-2-/- gerou uma maior susceptibilidade a infecções por Aspergillus (BALLOY et al., 2005); o polimorfismo em TLR-2 não resultou em aspergilose invasiva (CUNHA et al., 2013). Além de estar envolvido no reconhecimento de células fúngicas, TLR-2 também está presente nos mecanismos de resposta do hospedeiro a outros microrganismos como Staphylococcus, Mycobacterium e Pneumococcus (KOEDEL et al., 2003)

Em um trabalho realizado pelo nosso grupo, em colaboração com o grupo do Prof. Gordon Brown da Universidade de Exeter, mostrou que a baixa produção de TNF$\alpha$ por macrófagos na presença de $F$. pedrosoi, foi devido a uma ineficiente ativação de via de TLR, que foi prontamente reestabelecida com adição de um agonista desse receptor. Esse resultado demonstra uma complexa interação entre PRRs e $F$. pedrosoi que pode culminar na resistência/suscetibilidade da doença (SOUSA et al, 2011).

Nas duas últimas décadas, nosso entendimento sobre a cromoblastomicose e seu principal agente etiológico, F. pedrosoi, avançou consideravelmente. No entanto, um procedimento padrão para tratar a cromoblastomicose ainda não está disponível, assim sendo, o principal objetivo deste projeto é compreender a importância das interações de células dendríticas com o fungo $F$. pedrosoi, assim como a sua capacidade de migrar e induzir uma resposta protetora na cromoblastomicose experimental. 


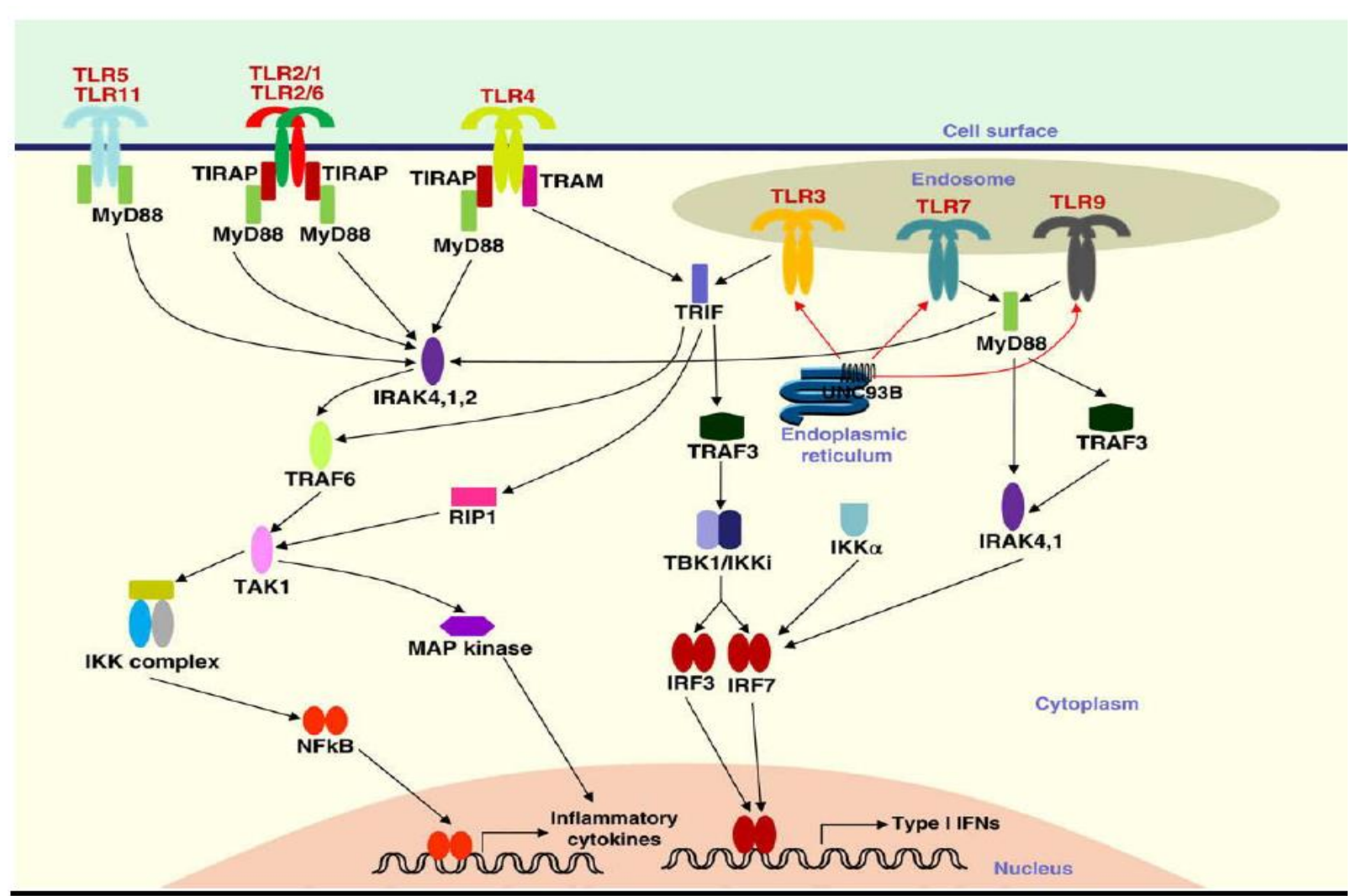

Figura 8. Vias de sinalização dos TLR-Like Receptors (TLR). Fonte: KUMAR et al., 2009.

\section{Objetivo}

\subsection{Objetivo Geral:}

- Analisar a reposta imune mediada por células dendríticas, previamente ativadas com o fungo $F$. pedrosoi e com agonistas de $T L R$, na cromoblastomicose experimental.

\subsection{Objetivos Específicos:}

In vivo:

- Observar a resposta imune protetora, induzidos por DCs que interagiram previamente com o fungo, na presença dos agonistas Pam3CSK4 e CpG-ODN, em camundongos infectados por $F$. pedrosoi por meio do ensaio de unidade formadora de colônia (CFU) de baço, fígado e linfonodo; 
- Imunofenotipagem das células de baço, fígado e linfonodo de animais imunizados por células dendríticas que interagiram previamente com $F$. pedrosoi e os agonistas PAM3CSK4 e CpG.

- Avaliar a produção de citocinas frente aos tratamentos administrados. 


\section{Material e Métodos}

\subsection{Animais}

Os animais utilizados foram camundongos isogênicos fêmeas da linhagem $\mathrm{BALB} / \mathrm{c}$, de 8 a 12 semanas de idade. Os animais foram mantidos em padrão sanitário livre de patógenos específicos (SPF) e alimentados com ração irradiada. Os camundongos foram eutanasiados em conformidade com os critérios propostos pela Comissão de Ética em Experimentação Animal da Faculdade de Ciências Farmacêuticas - CEUA/FCF com o protocolo 575 aprovado.

\subsection{Fungo}

Foi utilizada o fungo F. pedrosoi, cepa CBS 37.127 mantida em AgarSabouraud a $30^{\circ} \mathrm{C}$ com repiques quinzenais.

\subsection{Obtenção do conídio}

A obtenção dos conídios foi realizada utilizando o caldo batata (pobre em nutrientes), para uma obtenção maior em quantidade. Após o crescimento a colônia foi submetida à raspagem por alça de platina "L", e colocados em $150 \mathrm{ml}$ de caldo batata. Esse inoculo foi cultivado sob agitação de $160 \mathrm{rpm}$ a $30^{\circ} \mathrm{C}$ por 5 dias. Após o procedimento, o meio ficou em repouso, por 30 minutos para que as hifas sedimentem naturalmente. $\mathrm{O}$ sobrenadante que continha os conídios foi recolhido e centrifugado à $350 \mathrm{G}$ por 5 minutos para sedimentação de hifas, sendo retirado sobrenadante e o mesmo sendo centrifugado por $10.000 \mathrm{G}$ por 5 minutos. O fobrenadante foi descartado e o pellet foi quebrado na presença de 5 a $10 \mathrm{~mL}$ de PBS estéril. O número de conídios foi contado em câmera de Neubauer e ajustado conforme o ensaio.

\subsection{Inativação pelo calor (Heat Killed/ HK)}

Os conídios do fungo $F$. pedrosoi foram inativados por calor por meio de uma incubação a $75^{\circ} \mathrm{C}$ por 2 horas em banho Maria. A viabilidade deste inoculo foi avaliada após 7 dias em cultura em Agar Sabouraud à $25^{\circ} \mathrm{C}$ (CAPILLA et al., 2009). 
Posteriormente foi ajustada na concentração de $1 \times 10^{7}$ conídios, por meio de contagem em câmera de Neubauer.

\subsection{Experimentos in vitro}

\subsubsection{Obtenção e caracterização de células dendríticas}

As células dendríticas foram obtidas segundo o protocolo de Inaba et al, 1992. Células da medula óssea foram tiradas da tíbia e do fêmur dos camundongos, por meio de lavagem com uma concentração de RPMI com 10\% de albumina bovina (BSA). As células remanescentes foram cultivadas e suplementadas com $50 \mathrm{ng} / \mathrm{ml}$ de GM-CSF (recombinante Fator Estimulador de Colônias de Granulócitos e Macrófagos) (Life) por 7 dias na estufa a $37^{\circ} \mathrm{C}$ com $5 \%$ de $\mathrm{CO}_{2}$. No terceiro e quinto dias as células flutuantes (Granulócitos e linfócito) serão removidas, já as células que são aderentes foram recultivadas em meio RPMI com GM-CSF recombinante. No sétimo dia, as células aderidas, onde se encontra a população enriquecida de células dendríticas foram removidas e analisadas por citometria de fluxo, para verificar o marcador de superfície MHC-II, utilizando anticorpo anti-IA/I-E - PE, respectivamente para confirmar o fenótipo celular. A medida da fluorescência foi medida no FACS CANTO II (BD Bioscences, San Jose, CA, USA) e analisada no software FlowJo (Orlando, FL, USA).

\subsection{Experimentos In Vivo}

\subsubsection{Interação de DCs e $F$. pedrosoi na presença de agonistas de TLR}

As células dendríticas foram cultivadas em placas de 6 poços na concentração de $1 \times 10^{6}$ células/poço, interagindo com PAM3CSK4 (InvivoGen) e CPG (ODN1585, Class A- InvivoGen) nas concentrações de $8 \mathrm{ng} / \mu \mathrm{l}$ e $2 \mu \mathrm{M}$ respectivamente por duas horas, após foram interagidas com conídios de $F$. pedrosoi vivos e mortos por calor, na proporção de 1:10 por mais duas horas. Ao término foi retirado sobrenadante das placas de cultivo e adicionado $1 \mathrm{~mL}$ de PBS $1 \mathrm{X}$ estéril gelado nos poços e raspados em fluxo 
de fungo, esse sobrenadante então foi centrifugado à $1800 \mathrm{rpm}$ por 5 minutos e ressuspendidos em $100 \mu \mathrm{L}$ de PBS estéril.

\subsubsection{Imunização com DCs pulsadas com o fungo}

Os animais foram inoculados na região das coxas dos camundongos por via IM em uma suspensão de $1 \times 10^{6}$ de células dendríticas (DC), $1 \times 10^{6}$ de células dendríticas

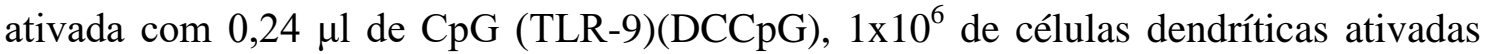

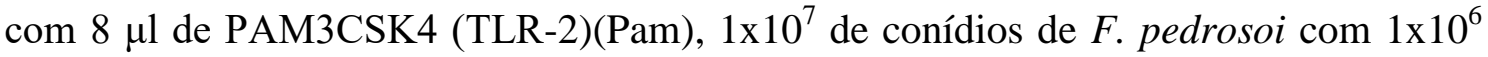
de células dendríticas (DCCO), $1 \times 10^{6}$ de células dendríticas com $1 \times 10^{7}$ de fungo morto por calor (DCHK), $1 \times 10^{6}$ de células dendríticas com $1 \times 10^{7}$ de conídio de $F$. pedrosoi juntamente com agonista de via TLR2 (PAM3CSK4) (DCCOP), 1×10 6 de células dendríticas com $1 \times 10^{7}$ de conídio de $F$. pedrosoi morto por calor $(\mathrm{HK})$ juntamente com agonista de via TLR2 (PAM3CSK4)(DCHKP), $1 \times 10^{6}$ de células dendríticas com 1×10 ${ }^{7}$ de conídio de F. pedrosoi juntamente com agonista de via TLR9 (CPG) (DCCOCpG), $1 \times 10^{6}$ de células dendríticas com $1 \times 10^{7}$ de conídio de $F$. pedrosoi morto por calor (HK) juntamente com agonista de via TLR9 (CpG)(DCHKCpG) e injetadas em um grupo de camundongos no volume de $100 \mu \mathrm{L}$, conforme especificações da Figura abaixo.

Após 7 dias de imunização, os camundongos foram infectados intraperitonealmente com inoculo do fungo $F$. pedrosoi em uma concentração de $1 \times 10^{7}$ em $100 \mu 1$ de PBS como descrito por CARDONA-CASTRO \&AGUDELO-FLOREZ, 1999. 


\section{Tratamento- IM}

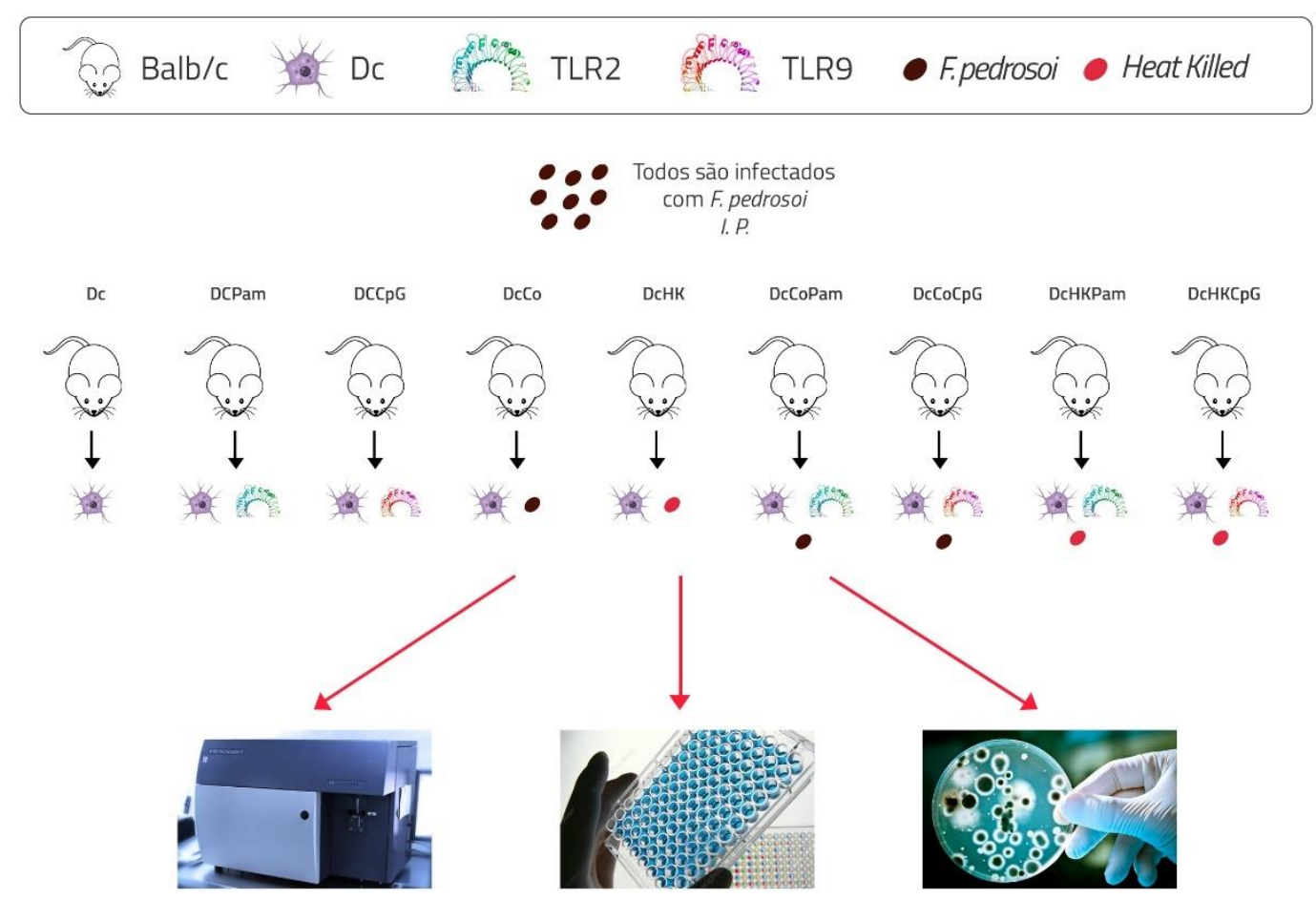

Figura 9. Esquema de imunização dos animais com DCs pulsadas com Fonsecaea pedrosoi.

\subsubsection{Imunofenotipagem do linfonodo com conídios vivos e} mortos de $F$. pedrosoi por citometria de fluxo.

Após 7 e 30 dias de infecção, os animais foram eutanasiados e os linfonodos poplíteos e inguinais foram macerados na presença de PBS estéril, centrifugados por 10 minutos a $3.500 \mathrm{rpm}$, o sobrenadante foi estocado a $-80^{\circ} \mathrm{C}$, que posteriormente será utilizado para dosagens de citocinas. Em seguida as células obtidas foram marcadas com anticorpos específicos, para a pesquisa de moléculas de superfície como: antiMHC-II -PE, anti-CD3 PE, anti-CD4 PERCPCY5 e anti-CD8 PECY7, anti-B220-PE, anti-CD-19 APCCY7, anti-IgM APC, indicando o fenótipo presente nas amostras. Estes anticorpos apresentam distinta fluorescência para possível caracterização celular. As células foram incubadas com os anticorpos por 20 minutos a $4^{\circ} \mathrm{C}$ e após este período foram lavadas com PBSA com 2\% de SFB( Vitrocel embriolife). 
A suspensão celular foi centrifugada por $1500 \mathrm{rpm}$ por 5 minutos a $4^{\circ} \mathrm{C}$, o sobrenadante foi desprezado e o pellet ressuspendido em $200 \mu \mathrm{L}$ de PBSA com $2 \%$ de soro fetal bovino (SFB). A medida da fluorescência foi medida no FACS CANTO II (BD Bioscences, San Jose, CA, USA) e analisada no software FlowJo (Orlando, FL, USA).

\subsubsection{Determinação de UFC}

O fígado e baço retirados dos animais foram colocados em placas de Petri estéreis e pesados rapidamente. Cada órgão foi homogeneizado mecanicamente com 2 $\mathrm{ml}$ e $1 \mathrm{ml}$, respectivamente, de PBS estéril e em seguida $100 \mu \mathrm{l}$ foram colocados em placas com ágar- Sabouraud em uma diluição 1:10. As placas foram mantidas a $30^{\circ} \mathrm{C}$ por 7 dias. As colônias fúngicas foram contadas e os valores estão exibidos em UFC/grama de órgão.

\subsubsection{Dosagem de citocinas (Elisa)}

As análises das citocinas foram realizadas com o sobrenadante utilizando o método ELISA (R\&D SYSTEMS), seguindo orientações do fabricante. As citocinas dosadas foram: IL-4, IL- 6, IL-10, IL-12, IL -17, IFN- $\gamma$.

Em uma placa de 96 poços foram colocados o anticorpo anti-citocina de interesse bem como o anticorpo de captura, diluído em solução salina tamponada com PBS $(50 \mu 1 /$ poço).

Durante toda a noite a placa foi mantida em temperatura ambiente, em seguida foi lavada três vezes em solução tamponada com fosfato contendo $0,05 \%$ de tween 20 (PBS- T), em 1 hora em temperatura ambiente em uma solução de bloqueio com $1 \%$ BSA em PBS 1x. Em duplicata, colocou- se a citocina recombinante para obter uma curva padrão de acordo com as instruções fornecidas pelo fabricante. A placa com as células foi lavada três vezes com PBS e anticorpo de detecção, a placa foi incubada por 2 horas em temperatura ambiente, após esse tempo, a placa foi lavada por mais três vezes na presença de PBS e foi colocado avidina conjugada à peroxidase, por 20 minutos em contato com a luz. Novamente foi lavada e foi adicionada uma solução reveladora constituída de tetrametilbenzidina (TMB). Após 20 minutos foi adicionado 
ácido sulfúrico $2 \mathrm{~N}$ para que a reação fosse bloqueada e a leitura seja feita a $450 \mathrm{~nm}$ em leitor de microplacas.

\section{Análise estatística}

A análise estatística aplicada aos resultados foi feita por meio de One-Way ANOVA, com possíveis comparações múltiplas por testes Tukey (ZAR, 1984). 


\section{CAPÍTULO I}

Análise da evolução da cromoblastomicose (CBM) murina após tratamento com células dendríticas pulsadas com $F$.pedrosoi vivo ou morto por calor (HK).

No presente capítulo avaliamos, por meio de análises de citometria de fluxo e quantificação de unidades formadoras de colônia, a capacidade de células dendríticas pulsadas com diferentes estágios do fungo $F$. pedrosoi (vivo e morto por calor) em desenvolver proteção contra a CBM murina. 


\section{Resultados}

\subsection{Citometria de Fluxo}

Com o objetivo de investigar o perfil de células $\mathrm{T}$ e $\mathrm{B}$ presentes nos linfonodos poplíteos e inguinais, após os animais passarem por imunização intramuscular na região das coxas, seguidas de uma infecção com conídios de $F$. pedrosoi por via intraperitoneal, estes foram removidos e as células totais foram utilizadas para marcação com anticorpos específicos.

Os anticorpos utilizados na Imunofenotipagem, pelo método de Citometria de Fluxo, foram anti-CD3 PE, anti-CD4 PERCPCY5, anti-CD8 PECY7, anti-B220-PE, anti-CD-19-APCCY7 e anti-IgM APC, onde avaliou-se as porcentagens de linfócitos TCD4 $\left(\mathrm{CD}^{+} \mathrm{CD}^{+}\right)$, TCD8 $\left(\mathrm{CD}^{+} \mathrm{CD}^{+}\right)$e linfócitos B (B220 ${ }^{+}, \mathrm{CD}-19^{+}, \mathrm{CD}-45^{+}$, $\operatorname{IgM}^{+)}$no baço e linfonodo dos animais tratados nos diferentes grupos utilizados nesse trabalho.

\subsubsection{Caracterização de subpopulações de células $T$ nos linfonodos de camundongos infectados por 7 dias após tratamento com células dendríticas pulsadas com agonistas de TLR-2 e TLR-9.}

Após 7 dias de infecção, as células obtidas do linfonodo foram analisadas, o grupo controle demonstrou uma maior porcentagem de células TCD8 quando comparada às células TCD4. Ao interagimos as células dendríticas com o agonista de via TLR-2 (Pam), observamos o mesmo perfil fenotípico, mas quando analisamos a interação entre células dendríticas com o agonista de TLR-9 (DCCpG), ocorreu um pequeno aumento na porcentagem de $\mathrm{TCD}^{+}$quando comparado ao $\mathrm{TCD} 8^{+}$

Ao analisarmos a interação das células dendríticas, com agonistas (Pam3CSK4 e CpG) e com conídios de $F$. pedrosoi vivo, a porcentagem dos tipos celulares presentes no linfonodo foi semelhante ao grupo $\mathrm{DCCO}$, nos quais a porcentagem de células 
$\mathrm{TCD}^{+}$apresentou $26,7 \%$ enquanto $\mathrm{TCD}^{+} 34,5 \%$, respectivamente. Quando foram analisados os grupos com a interação dos agonistas e conídios vivos não observamos mudanças significativas na porcentagem celular, os quais se aproximaram ao grupo controle (DC).

A análise nos linfonodos poplíteos e inguinais dos grupos nos quais as interações foram feitas com conídios mortos por calor (Heat Killed/ HK) e juntamente com agonistas de vias TLR-2 e TLR-9, conseguimos observar que a porcentagem de células $\mathrm{TCD}^{+} \mathrm{e}^{\mathrm{TCD}} 8^{+}$foram semelhantes quando comparados aos grupos anteriores, conforme Figura 10. A porcentagem dessas células não apresentou alterações significativas quando comparadas com o grupo controle (DC), conforme Figura 11 e 12. 

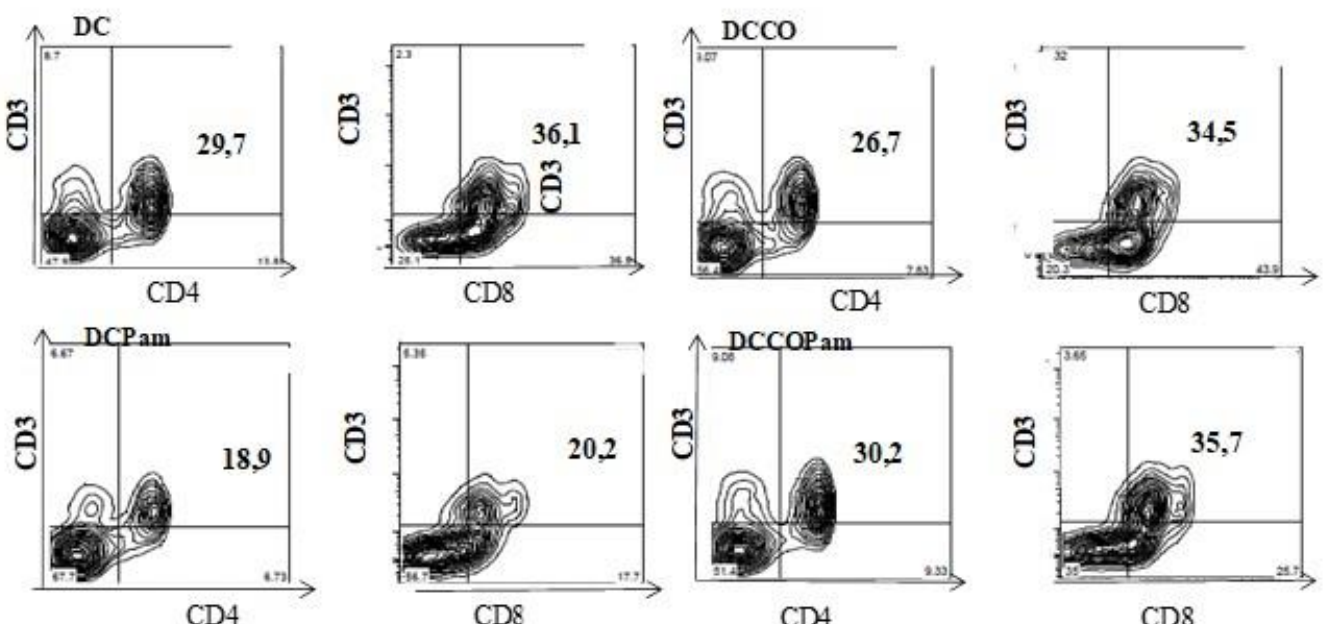

CD4

CD8
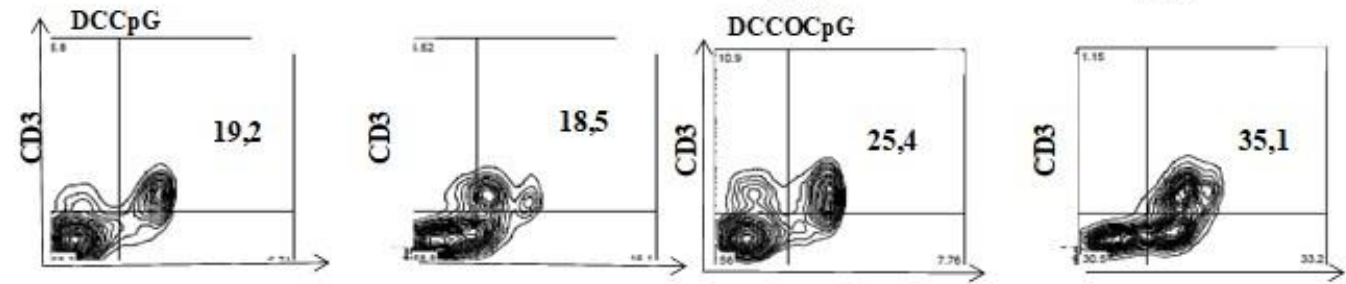

$\mathrm{CD} 4$

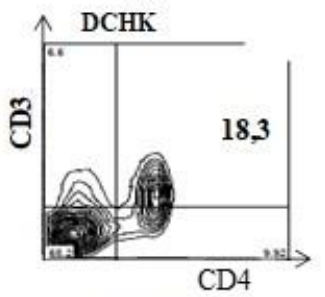

CD8

CD4
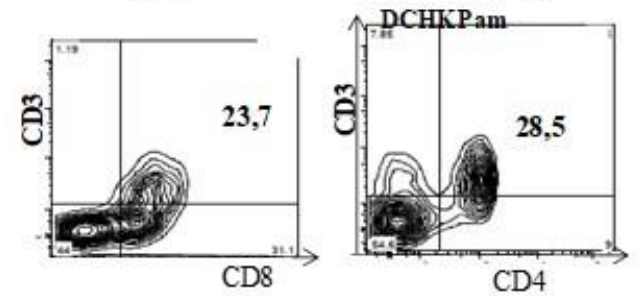

CD8

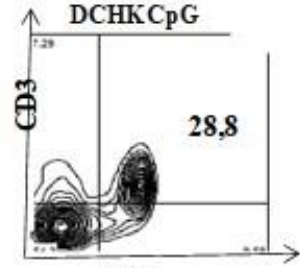

CD8

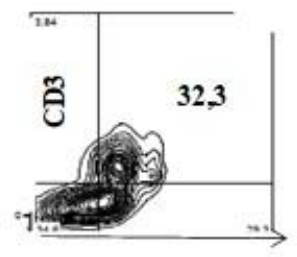

CD4

Figura 10. Análise fenotípica de células CD3+/CD4+ CD3+/CD8+ do linfonodo obtidas em experimento in vivo. Camundongos BALB/c (3 a 5 animais por grupo) foram divididos em 9 grupos e posteriormente, submetidos a inoculação, por via intramuscular, da seguinte forma: $1 \times 10^{6}$ de células dendríticas

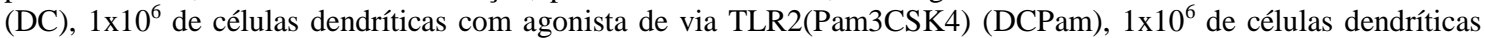
juntamente com agonista de TLR9 $(\mathrm{CpG})(\mathrm{DCCpG}), 1 \times 10^{7}$ de conídios de $F$. pedrosoi com $1 \times 10^{6}$ de células dendríticas (DCCO), $1 \times 10^{6}$ de células dendríticas com $1 \times 10^{7}$ de fungo morto por calor (DCHK), 1x10 6 de células dendríticas com $1 \times 10^{7}$ de conídio de F. pedrosoi juntamente com agonista de via TLR2 (Pam3CSK4) (DCCOPam), $1 \times 10^{6}$ de células dendríticas com $1 \times 10^{7}$ de conídio de $F$. pedrosoi morto por calor (HK) juntamente com agonista de via TLR2 (Pam3CSK4)(DCHKPam), $1 \times 10^{6}$ de células dendríticas com $1 \times 10^{7}$ de fungo morto por calor juntamente com agonista de via TLR9 (CpG) (DCHKCpG), ), $1 \times 10^{6}$ de células dendríticas com 1 $10^{7}$ de conídio de $F$. pedrosoi juntamente com agonista de via TLR9 (CpG) (DCCOCpG). Após 7 dias os camundongos foram submetidos a uma infecção intraperitoneal e eutanasiados ao sétimo dia. As células foram então marcadas com anti- CD3/CD4 e anti$\mathrm{CD} 3 / \mathrm{CD} 8$. 
Linfonodo 7D Conídio

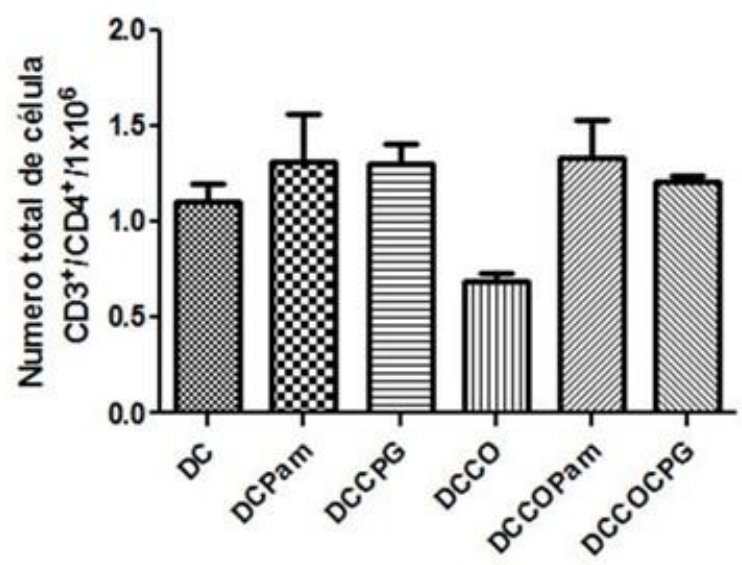

Linfonodo 7D HK

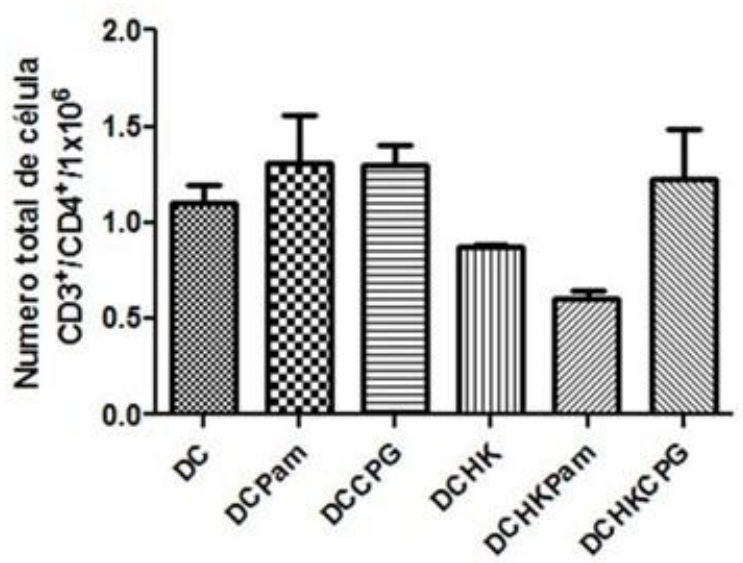

Figura 11. Análise fenotípica de células CD3+/CD4+ do linfonodo obtidas em experimento in vivo. Camundongos BALB/c (3 a 5 animais por grupo) foram divididos em 9 grupos e posteriormente, submetidos a inoculação, por via intramuscular, da seguinte forma: $1 \times 10^{6}$ de células dendríticas (DC), 1×10 de células dendríticas com agonista de via TLR2(Pam3CSK4) (DCPam), $1 \times 10^{6}$ de células dendríticas juntamente com agonista de TLR9 (CpG) (DCCpG), $1 \times 10^{7}$ de conídios de $F$. pedrosoi com $1 \times 10^{6}$ de células dendríticas (DCCO), $1 \times 10^{6}$ de células dendríticas com $1 \times 10^{7}$ de fungo morto por calor (DCHK), $1 \times 10^{6}$ de células dendríticas com $1 \times 10^{7}$ de conídio de $F$.

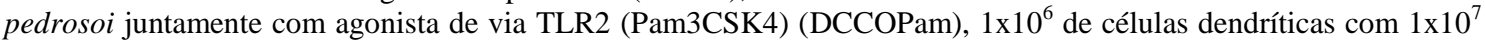
de conídio de F. pedrosoi morto por calor (HK) juntamente com agonista de via TLR2 (Pam3CSK4)(DCHKPam), $1 \times 10^{6}$ de células dendríticas com $1 \times 10^{7}$ de fungo morto por calor juntamente com agonista de via TLR9 (CpG) (DCHKCpG), ), $1 \times 10^{6}$ de células dendríticas com $1 \times 10^{7}$ de conídio de $F$. pedrosoi juntamente com agonista de via TLR9 (CpG) (DCCOCpG). Após 7 dias os camundongos foram submetidos a uma infecção intraperitoneal e eutanasiados ao sétimo dia. As células foram então marcadas com anti- CD3/CD4 e anti-CD3/CD8.No gráfico de barra, cada barra representa a média +DP. Os dados são representativos do experimento (NS).

Linfonodo 7D Conídio

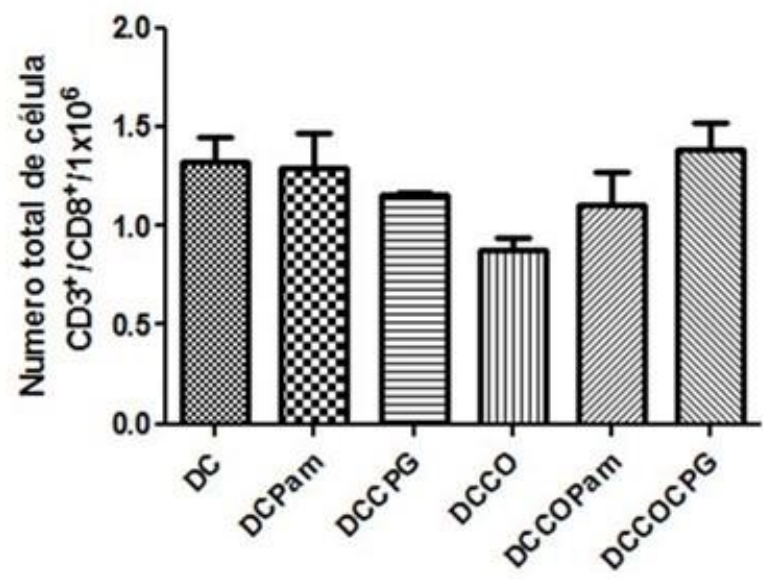

Linfonodo 7D HK

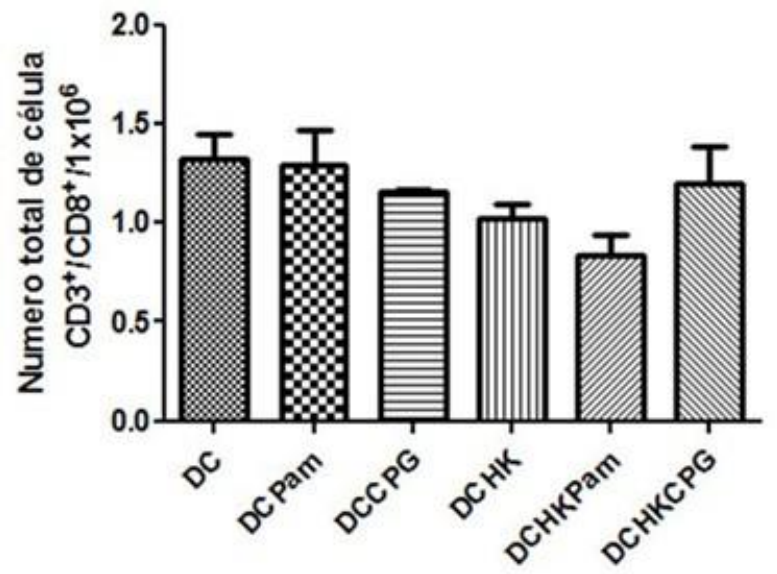

Figura 12. Análise fenotípica de células CD3+/CD8+ do linfonodo obtidas em experimento in vivo. Camundongos BALB/c (3 a 5 animais por grupo) foram divididos em 9 grupos e posteriormente, submetidos a inoculação, por via intramuscular, da seguinte forma: $1 \times 10^{6}$ de células dendríticas (DC), $1 \times 10^{6}$ de células dendríticas com agonista de via TLR2(Pam3CSK4) (DCPam), 1×10 de células dendríticas juntamente com agonista de TLR9 (CpG) (DCCpG), $1 \times 10^{7}$ de conídios de F. pedrosoi com $1 \times 10^{6}$ de células dendríticas (DCCO), $1 \times 10^{6}$ de células dendríticas com $1 \times 10^{7}$ de fungo morto por calor (DCHK), $1 \times 10^{6}$ de células dendríticas com $1 \times 10^{7}$ de conídio de $F$.

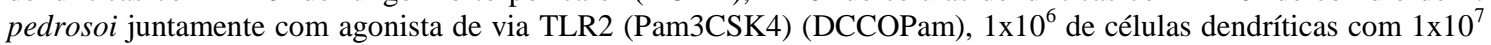
de conídio de $F$. pedrosoi morto por calor (HK) juntamente com agonista de via TLR2 (Pam3CSK4)(DCHKPam), $1 \times 10^{6}$ de células dendríticas com $1 \times 10^{7}$ de fungo morto por calor juntamente com agonista de via TLR9 (CpG) 
(DCHKCpG), ), $1 \times 10^{6}$ de células dendríticas com $1 \times 10^{7}$ de conídio de $F$. pedrosoi juntamente com agonista de via TLR9 (CpG) (DCCOCpG). Após 7 dias os camundongos foram submetidos a uma infecção intraperitoneal e eutanasiados ao sétimo dia. As células foram então marcadas com anti- CD3/CD4 e anti-CD3/CD8.

No gráfico de barra, cada barra representa a média +DP. Os dados são representativos do experimento (NS).

\subsubsection{Caracterização de subpopulações de células $B$ nos} linfonodos de camundongos infectados por 7 dias após tratamento com células dendríticas pulsadas com agonistas de TLR-2 e TLR-9.

Após 7 dias de infecção, as células obtidas do linfonodo poplíteos e inguinais, foram analisadas com base em moléculas de superfície marcadas com fluorocromos específicos e analisadas por citometria de fluxo. Podemos observar que o grupo controle apresenta 25,5\% de células do tipo LB. Quando interagimos as células dendríticas com o agonista de via TLR-2(Pam), observamos um aumento da porcentagem no perfil fenotípico, apresentando 33,2\% de células duplamente marcadas, em contra partida, quando analisamos a interação entre células dendríticas e agonista de TLR-9 (DCCpG), podemos notar uma diminuição estatisticamente significativa comparado ao nosso grupo controle (DC), apresentando somente 19,8\% de células duplamente marcadas. Maglione e colaboradores (2015) relataram em estudo recente uma baixa proliferação de linfócitos B e defeitos na ativação e secreção de citocinas das mesmas.

Ao analisarmos os grupos já interagidos com conídios vivos de $F$. pedrosoi (CO), conídios mortos por calor de F. pedrosoi (HK) e agonistas de via TLR-2 e TLR-9 observamos a porcentagem de células presentes no linfonodo e verificamos que a interação somente com o conídio o perfil de células aumenta em comparação ao nosso primeiro grupo, o grupo controle (DC), apresentando 30,6\% de células duplamente marcadas. Quando foram analisados os grupos com a interação dos agonistas e conídios vivos observamos mudanças na porcentagem. No momento em que a via de sinalização TLR-2 está ativada, conseguimos notar um aumento nas células duplamente marcadas, em comparação ao grupo controle (DC), apresentando 34,8\% de células nos linfonodos, diferentemente, quando o TLR-9 é previamente estimulado podemos notar uma diminuição na porcentagem de células duplamente marcadas, apresentando somente $25,9 \%$. 
Realizada análise semelhante nos linfonodos poplíteos e inguinais com grupos nos quais as interações foram feitas com conídios mortos por calor (heat killed/ HK), juntamente com agonistas de vias TLR-2 e TLR-9, conseguimos observar que a porcentagem de Linfócitos $\mathrm{B}^{+}$estão diminuídas em todos os grupos, conforme Figura 13. Essas células apresentaram diferença estatística, nas quais podemos observar a presença de linfócitos do tipo B principalmente no grupo de células dendríticas, previamente estimuladas com Pam3CSK4, agonista de via TLR-2. Entretanto, conseguimos observar que, quando essas células são estimuladas também por heat killed (conídio morto por calor/HK) as porcentagens de células nos linfonodos diminuem, conforme Figura 14. 

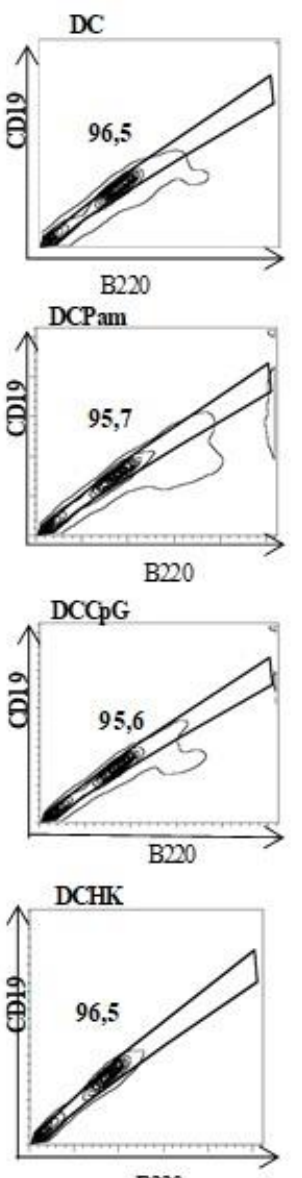

B 220

\section{DCHKPam}

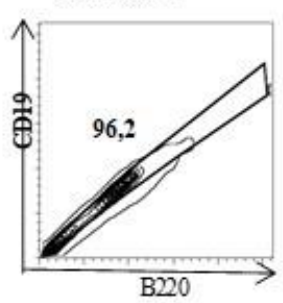

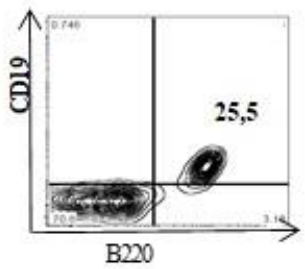

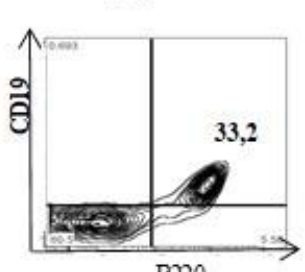

B220
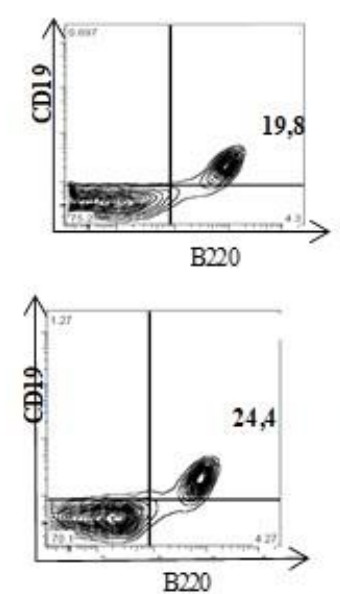

B220

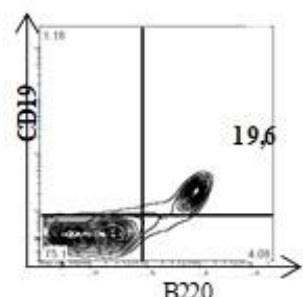

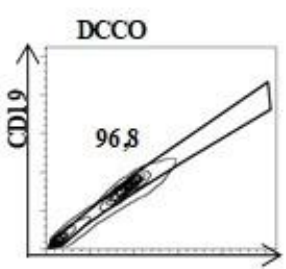

B220

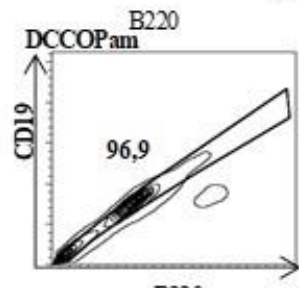

B220

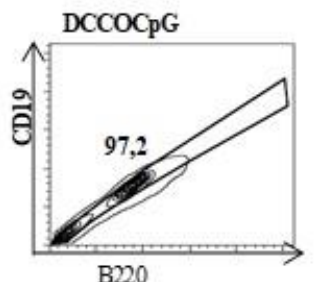

CHKCpG

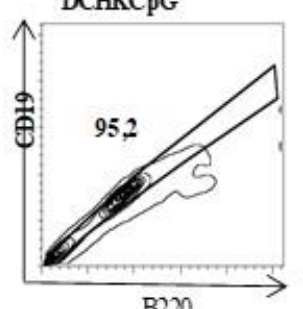

B220

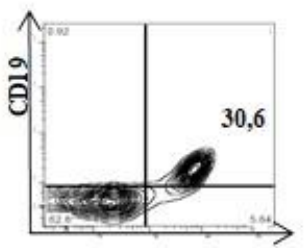

B220
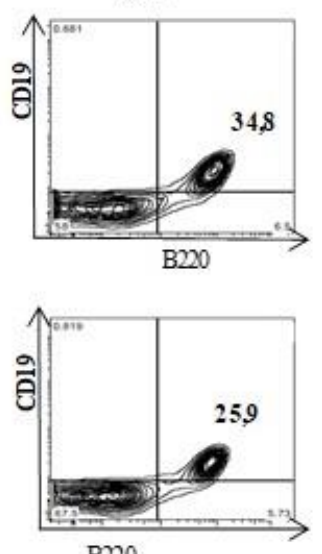

B220

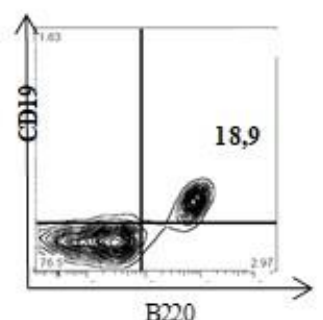

Figura 13. Análise fenotípica de células B220+/CD19+ do linfonodo obtidas em experimento in vivo. Camundongos BALB/c (3 a 5 animais por grupo) foram divididos em 9 grupos e posteriormente, submetidos a inoculação, por via intramuscular, da seguinte forma: 1x106 de células dendríticas (DC), 1x106 de células dendríticas com agonista de via TLR2(Pam3CSK4) (Pam), 1x106 de células dendríticas juntamente com agonista de TLR9 (CpG) (DCCpG), 1x106 de conídios de F. pedrosoi com 1×106 de células dendríticas (DCCO), 1x106 de células dendríticas com 1x106 de fungo morto por calor (DCHK), 1x106 de células dendríticas com 1x106 de conídio de F. pedrosoi juntamente com agonista de via TLR2 (Pam3CSK4) (DCCOPam), 1x106 de células dendríticas com 1x106 de conídio de F. pedrosoi morto por calor (HK) juntamente com agonista de via TLR2 (Pam3CSK4)(DCHKPam), 1x106 de células dendríticas com 1x106 de fungo morto por calor juntamente com agonista de via TLR9 (CpG) (DCHKCpG), ), 1x106 de células dendríticas com 1x106 de conídio de F. pedrosoi juntamente com agonista de via TLR9 (CpG) (DCCOCpG). Após 7 dias os camundongos foram submetidos a uma infecção intraperitoneal e eutanasiado ao sétimo dia. As células foram então marcadas com anti- B220 e anti-CD19. 

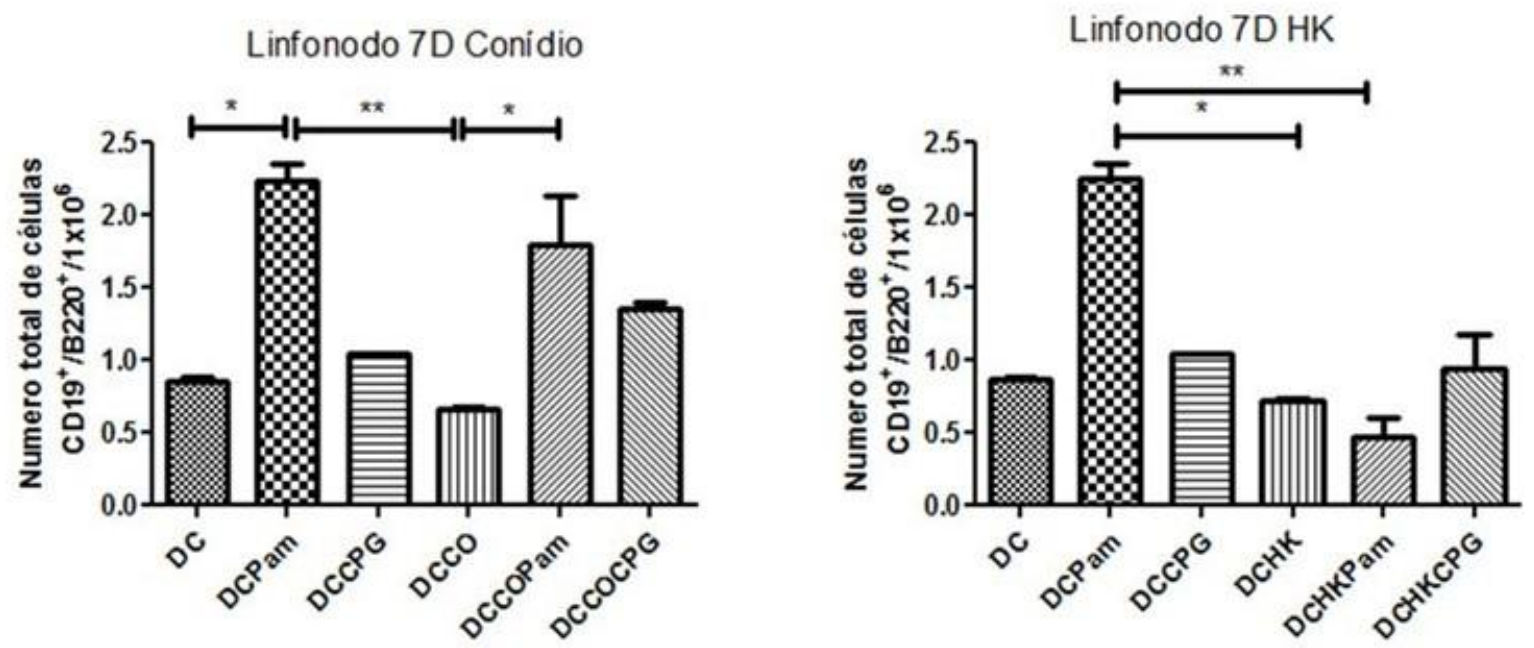

Figura 14. Análise fenotípica de células B220+/CD19+ do linfonodo obtidas em experimento in vivo. Camundongos BALB/c (3 a 5 animais por grupo) foram divididos em 9 grupos e posteriormente, submetidos a inoculação, por via intramuscular, da seguinte forma: $1 \times 10^{6}$ de células dendríticas (DC), $1 \times 10^{6}$ de células dendríticas com agonista de via TLR2(Pam3CSK4) (DCPam), $1 \times 10^{6}$ de células dendríticas juntamente com agonista de TLR9 $(\mathrm{CpG})(\mathrm{DCCpG}), 1 \times 10^{7}$ de conídios de $F$. pedrosoi com $1 \times 10^{6}$ de células dendríticas (DCCO), $1 \times 10^{6}$ de células dendríticas com $1 \times 10^{7}$ de fungo morto por calor (DCHK), $1 \times 10^{6}$ de células dendríticas com $1 \times 10^{7}$ de conídio de $F$.

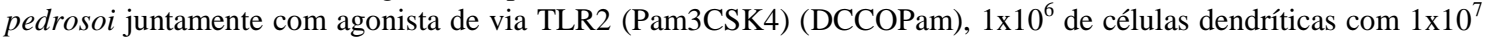
de conídio de $F$. pedrosoi morto por calor (HK) juntamente com agonista de via TLR2 (Pam3CSK4)(DCHKPam), $1 \times 10^{6}$ de células dendríticas com $1 \times 10^{7}$ de fungo morto por calor juntamente com agonista de via TLR9 (CpG) (DCHKCpG), ), $1 \times 10^{6}$ de células dendríticas com $1 \times 10^{7}$ de conídio de $F$. pedrosoi juntamente com agonista de via TLR9 (CpG) (DCCOCpG). Após 7 dias os camundongos foram submetidos a uma infecção intraperitoneal e eutanasiados ao sétimo dia. As células foram então marcadas com anti- B220 e anti-CD19.

No gráfico de barra, cada barra representa a média $+\mathrm{DP}$. Os dados são representativos do experimento $(* \mathrm{P}<0,05$, $* * \mathrm{P}<0,01)$.

Em resumo, o perfil de células B demonstrou uma presença maior no grupo tratado com conídios de F. pedrosoi e agonista de TLR2 (Pam3CSK4), quando comparado ao grupo tratado somente com conídios.

\subsubsection{Caracterização de moléculas de MHC-II nos linfonodos de camundongos infectados por 7 dias após tratamento com células dendríticas pulsadas com agonistas de TLR-2 e TLR-9.}

Em busca de resultados que corroborassem com os dados obtidos acima, investigando o perfil celular de células obtidas dos linfonodos poplíteos e inguinais, que foram marcados com fluorocromo de superfície as moléculas de MHC-II, conseguimos observar que não ocorreu uma alta expressão dessas moléculas. Todos os grupos apresentaram um padrão de expressão de MHC de classe II semelhantes, no entanto o 
grupo DCHKPam (células dendríticas estimuladas com agonistas de via TLR-2 juntamente com heat killed) teve uma baixa expressão dessas moléculas quando comparado ao DCCOPam (células dendríticas estimuladas com agonistas de via TLR-2 juntamente com conídios vivos de F. pedrosoi). Podemos observar juntamente com esse dado que, quando a imunização foi realizada somente com células dendríticas e Pam3SCK4, obtivemos uma expressão maior de moléculas de MHC-II quando comparada a interação semelhante, porém com o acréscimo de heat killed, nos mostra estatisticamente uma diminuição dessa expressão.

Hayakawa e colaboradores (2006), após compararem a interação entre células fagociticas e as espécies $C$. carrionii, F. pedrosoi, $P$. verrucosa e $R$. aquaspersa, observaram que apesar do F. pedrosoi ser o mais fagocitado ele é capaz de induzir uma baixa expressão do complexo de histocompatibilidade de classe II (MHC-II), conforme Figura 15 e 16. 

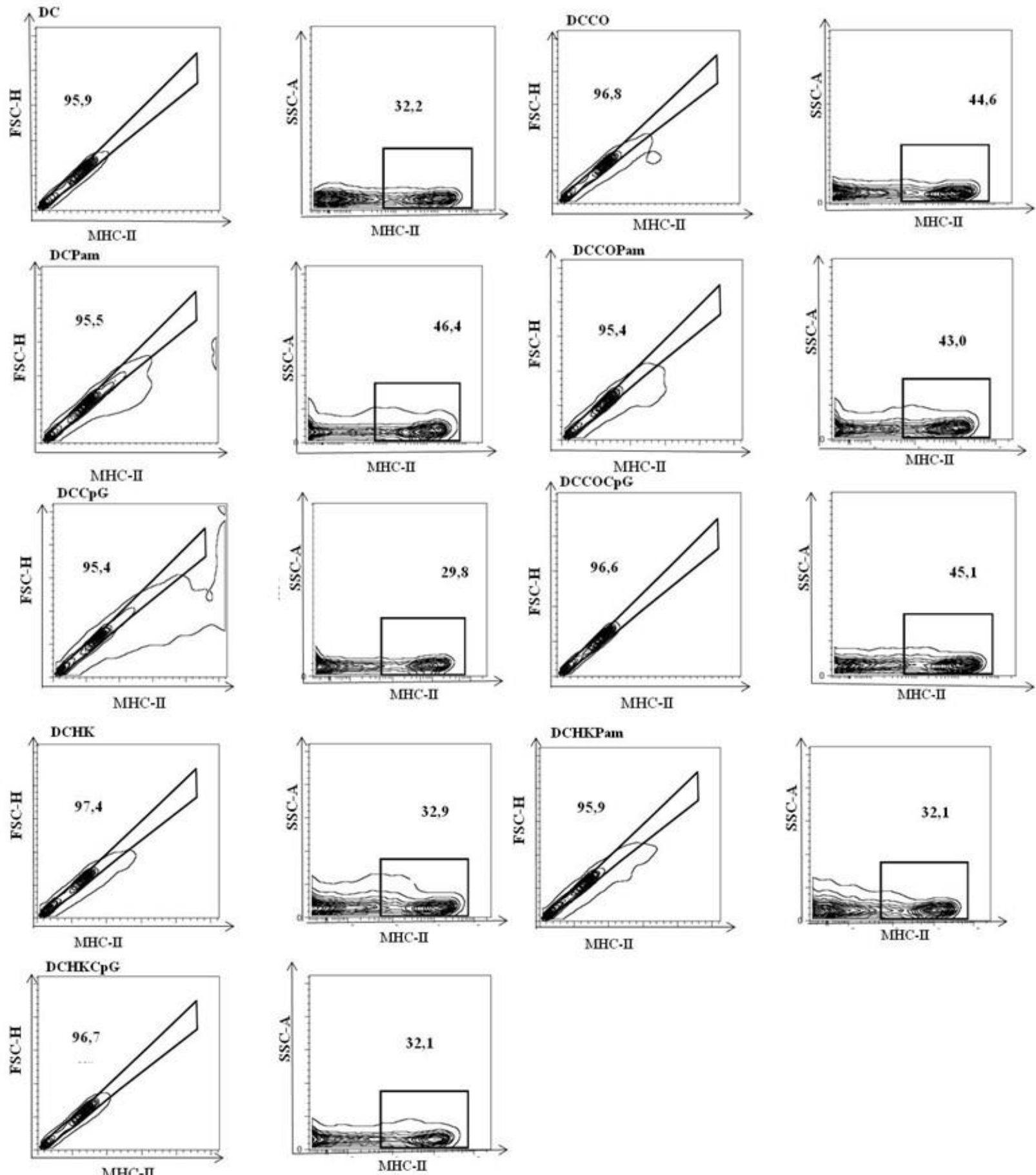

Figura 15. Análise fenotípica de células MHC-II+ do linfonodo obtidas em experimento in vivo. Camundongos BALB/c ( 3 a 5 animais por grupo) foram divididos em 9 grupos e posteriormente, submetidos a inoculação, por via intramuscular, da seguinte forma: $1 \times 10^{6}$ de células dendríticas (DC), $1 \times 10^{6}$ de células dendríticas com agonista de via TLR2(Pam3CSK4) (DCPam), $1 \times 10^{6}$ de células dendríticas juntamente com agonista de TLR9 $(\mathrm{CpG})(\mathrm{DCCpG}), 1 \times 10^{7}$ de conídios de $F$. pedrosoi com $1 \times 10^{6}$ de células dendríticas (DCCO), $1 \times 10^{6}$ de células dendríticas com $1 \times 10^{7}$ de fungo morto por calor (DCHK), $1 \times 10^{6}$ de células dendríticas com $1 \times 10^{7}$ de conídio de $F$.

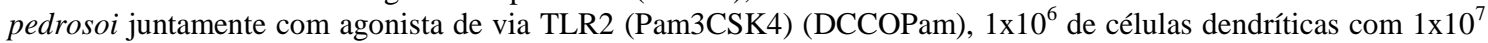
de conídio de F. pedrosoi morto por calor (HK) juntamente com agonista de via TLR2 (Pam3CSK4)(DCHKPam), $1 \times 10^{6}$ de células dendríticas com $1 \times 10^{7}$ de fungo morto por calor juntamente com agonista de via TLR9 (CpG) (DCHKCpG), ), $1 \times 10^{6}$ de células dendríticas com $1 \times 10^{7}$ de conídio de $F$. pedrosoi juntamente com agonista de via TLR9 (CpG) (DCCOCpG). Após 7 dias os camundongos foram submetidos a uma infecção intraperitoneal e eutanasiados ao sétimo dia. As células foram então marcadas com anti- MHC-II. 
Linfonodo 7D Conídio

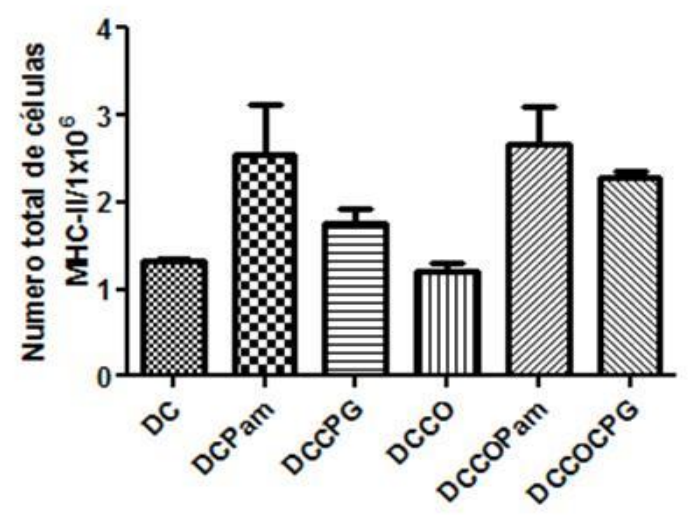

Linfonodo 7D HK

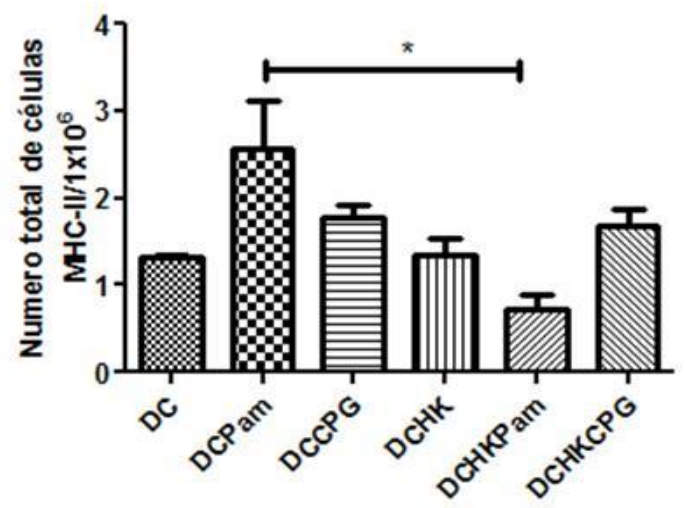

Figura 16. Análise fenotípica de células MHC-II+ linfonodo obtidas em experimento in vivo. Camundongos BALB/c ( 3 a 5 animais por grupo) foram divididos em 9 grupos e posteriormente, submetidos a inoculação, por via intramuscular, da seguinte forma: $1 \times 10^{6}$ de células dendríticas (DC), $1 \times 10^{6}$ de células dendríticas com agonista de via TLR2(Pam3CSK4) (DCPam), 1×10 de células dendríticas juntamente com agonista de TLR9 $(\mathrm{CpG})(\mathrm{DCCpG}), 1 \times 10^{7}$ de conídios de $F$. pedrosoi com $1 \times 10^{6}$ de células dendríticas (DCCO), $1 \times 10^{6}$ de células dendríticas com $1 \times 10^{7}$ de fungo morto por calor (DCHK), $1 \times 10^{6}$ de células dendríticas com $1 \times 10^{7}$ de conídio de $F$.

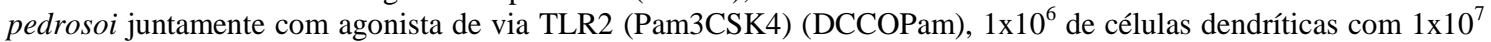
de conídio de F. pedrosoi morto por calor (HK) juntamente com agonista de via TLR2 (Pam3CSK4)(DCHKPam), $1 \times 10^{6}$ de células dendríticas com $1 \times 10^{7}$ de fungo morto por calor juntamente com agonista de via TLR9 (CpG) (DCHKCpG), ), $1 \times 10^{6}$ de células dendríticas com $1 \times 10^{7}$ de conídio de $F$. pedrosoi juntamente com agonista de via TLR9 (CpG) (DCCOCpG). Após 7 dias os camundongos foram submetidos a uma infecção intraperitoneal e eutanasiado ao sétimo dia. As células foram então marcadas com anti-MHC-II. No gráfico de barra, cada barra representa a média +DP. Os dados são representativos do experimento $(* \mathrm{P}<0,05)$.

Em resumo, os nossos dados mostraram que a imunização com células dendríticas pulsadas com o fungo e agonistas de TLR, não induziram alterações significativas na molécula de MHC-II após 7 dias de infecção.

\subsubsection{Caracterização de subpopulações de células $T$ nos linfonodos de camundongos infectados por 30 dias após tratamento com células dendríticas pulsadas com agonistas de TLR-2 e TLR-9.}

O grupo de células dendríticas estimulados somente com $\mathrm{CpG}$ foi o que obteve uma menor ativação estatística de células do tipo $\mathrm{TCD}^{+}{ }^{+}$principalmente quando comparada com o grupo DCCOPam, que possui a interação de células dendríticas juntamente com conídios de F. pedrosoi e Pam3CSK4, conforme Figura 17.

O grupo DCCOPam também demonstrou dados significantes quando comparado ao DCCOCpG, onde este último grupo apresentou uma baixa ativação de células do tipo $\mathrm{TCD} 4^{+}$. 
Quando interagidos com heat killed, tanto o grupo previamente estimulado com Pam3CSK4(DCHKPam), quanto o grupo previamente estimulado com CpG (DCHKCpG), obtiveram uma alta ativação quando comparados com o grupo que tinha apenas a interação de células dendríticas e $\mathrm{CpG}(\mathrm{DCCpG})$, conforme Figura 18.

Ao analisarmos a ativação de linfócito $\mathrm{TCD}^{+}$, conseguimos notar uma baixa ativação dessa classe de linfócitos no grupo estimulado somente com agonista de via TLR-9 (CpG)(DCCpG), quando comparado com o grupo DCCOPam (células dendríticas interagidas com conídios vivos de $F$. pedrosoi juntamente com agonista de TLR-2).

Ao interagirmos com conídio morto por calor, percebemos que houve uma notória diferença estatística entre o grupo DCCpG e DCHK quando comparados com o grupo DCHKCpG, no qual notamos uma maior ativação de células do tipo $\mathrm{TCD}^{+}$do mesmo. Evidenciando que quando interagidos, eles conseguem desenvolver uma ativação satisfatória de tais células. 


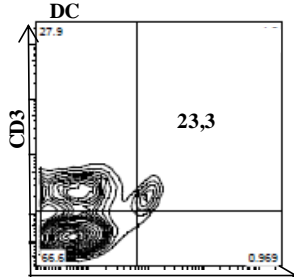

CD4

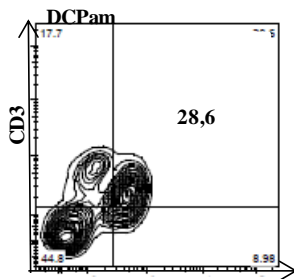

CD4

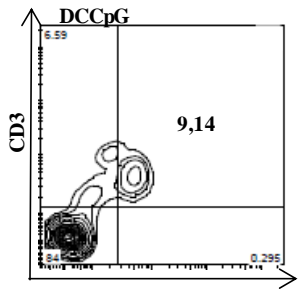

CD4

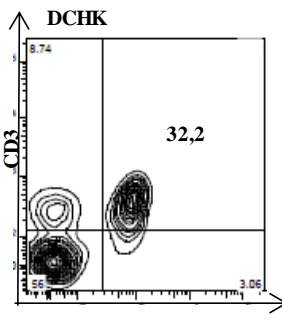

CD4

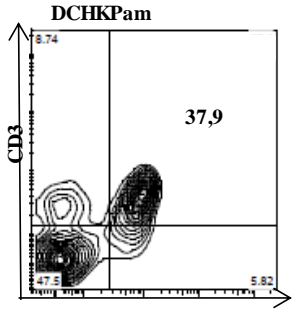

CD4

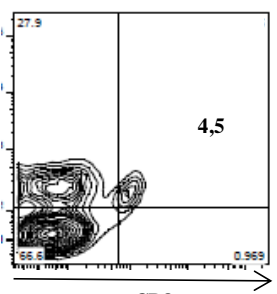

CD8

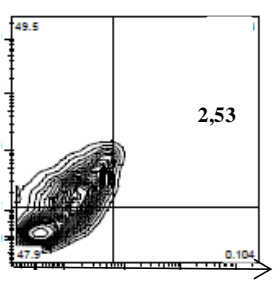

CD8

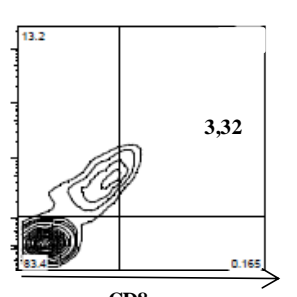

CD8

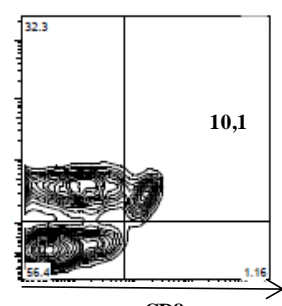

CD8

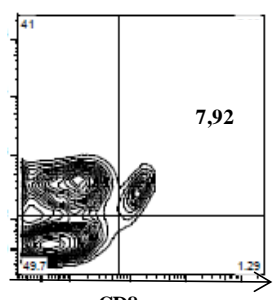

CD8

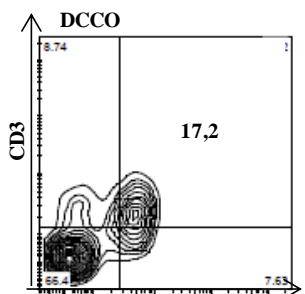

CD4

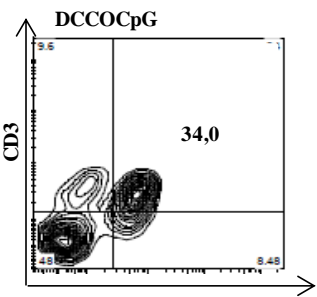

CD4

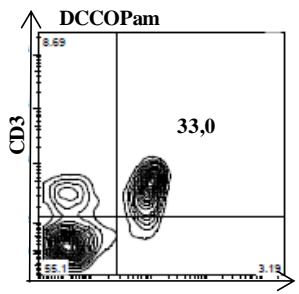

CD4

DCHKCpG

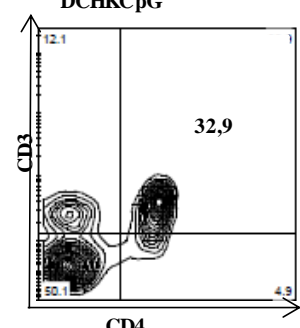

CD4

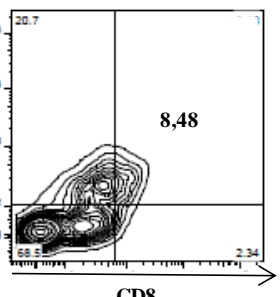

CD8

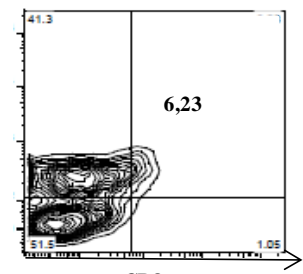

CD8

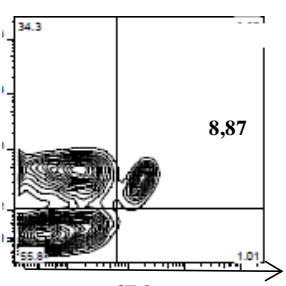

CD8

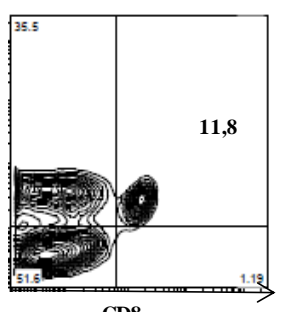

Figura 17. Análise fenotípica de células CD3+/CD4+ CD3+/CD8+ do linfonodo obtidas em experimento in vivo. Camundongos BALB/c ( 3 a 5 animais por grupo) foram divididos em 9 grupos $\mathrm{e}$ posteriormente, submetidos a inoculação, por via intramuscular, da seguinte forma: $1 \times 10^{6}$ de células dendríticas (DC), $1 \times 10^{6}$ de células dendríticas com agonista de via TLR2(Pam3CSK4) (DCPam), $1 \times 10^{6}$ de células dendríticas juntamente com agonista de TLR9 (CpG) (DCCpG), $1 \times 10^{7}$ de conídios de $F$. pedrosoi com $1 \times 10^{6}$ de células dendríticas (DCCO), $1 \times 10^{6}$ de células dendríticas com $1 \times 10^{7}$ de fungo morto por calor (DCHK), $1 \times 10^{6}$ de células dendríticas com $1 \times 10^{7}$ de conídio de F. pedrosoi juntamente com agonista de via TLR2 (Pam3CSK4) (DCCOPam), $1 \times 10^{6}$ de células dendríticas com $1 \times 10^{7}$ de conídio de $F$. pedrosoi morto por calor (HK) juntamente com agonista de via TLR2 (Pam3CSK4)(DCHKPam), $1 \times 10^{6}$ de células dendríticas com 1 $10^{7}$ de fungo morto por calor juntamente com agonista de via TLR9 (CpG) (DCHKCpG), ), $1 \times 10^{6}$ de células dendríticas com $1 \times 10^{7}$ de conídio de $F$. pedrosoi juntamente com agonista de via TLR9 $(\mathrm{CpG})(\mathrm{DCCOCpG})$. Após 7 dias os camundongos foram submetidos a uma infecção intraperitoneal e eutanasiado ao trigésimo dia. As células foram então marcadas com anti- CD3/CD4 e anti$\mathrm{CD} 3 / \mathrm{CD} 8$ 
Linfonodo 30D Conidio

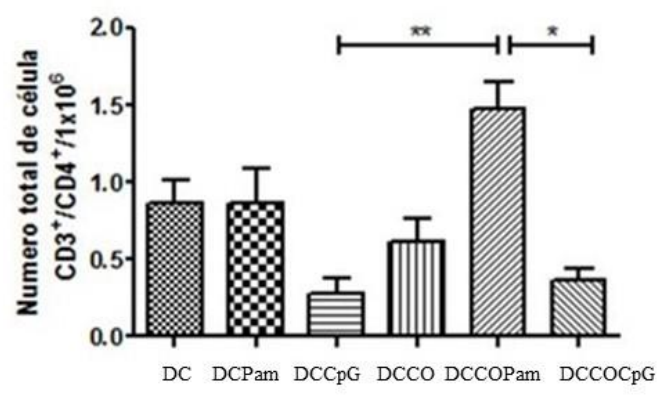

Linfonodo 30D HK

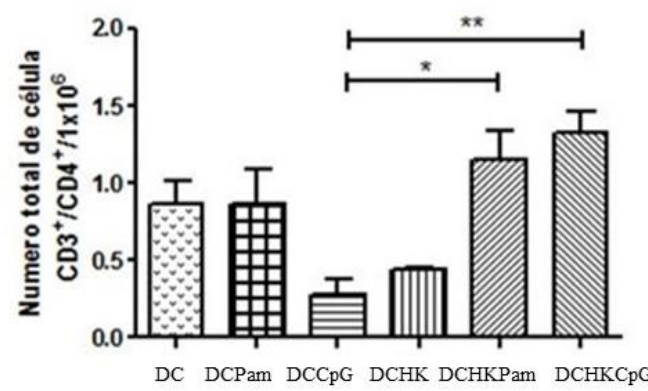

Figura 18. Análise fenotípica de células CD3+/CD4+ do linfonodo obtidas em experimento in vivo. Camundongos BALB/c (3 a 5 animais por grupo) foram divididos em 9 grupos e posteriormente, submetidos a inoculação, por via intramuscular, da seguinte forma: $1 \times 10^{6}$ de células dendríticas (DC), $1 \times 10^{6}$ de células dendríticas com agonista de via TLR2(Pam3CSK4) (DCPam), $1 \times 10^{6}$ de células dendríticas juntamente com agonista de TLR9 $(\mathrm{CpG})(\mathrm{DCCpG}), 1 \times 10^{7}$ de conídios de $F$. pedrosoi com $1 \times 10^{6}$ de células dendríticas (DCCO), $1 \times 10^{6}$ de células dendríticas com $1 \times 10^{7}$ de fungo morto por calor (DCHK), $1 \times 10^{6}$ de células dendríticas com $1 \times 10^{7}$ de conídio de $F$.

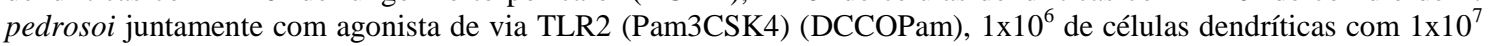
de conídio de $F$. pedrosoi morto por calor (HK) juntamente com agonista de via TLR2 (Pam3CSK4)(DCHKPam), $1 \times 10^{6}$ de células dendríticas com $1 \times 10^{7}$ de fungo morto por calor juntamente com agonista de via TLR9 (CpG) (DCHKCpG), ), $1 \times 10^{6}$ de células dendríticas com $1 \times 10^{7}$ de conídio de $F$. pedrosoi juntamente com agonista de via TLR9 (CpG) (DCCOCpG). Após 7 dias os camundongos foram submetidos a uma infecção intraperitoneal e eutanasiado ao trigésimo dia. As células foram então marcadas com anti- CD3/CD4 seguidos de counter plot com porcentagens de células. No gráfico de barra, cada barra representa a média +DP. Os dados são representativos do experimento $(* \mathrm{P}<0,05, * * \mathrm{P}<0,01)$.

\section{Linfonodo 30D Conidio}

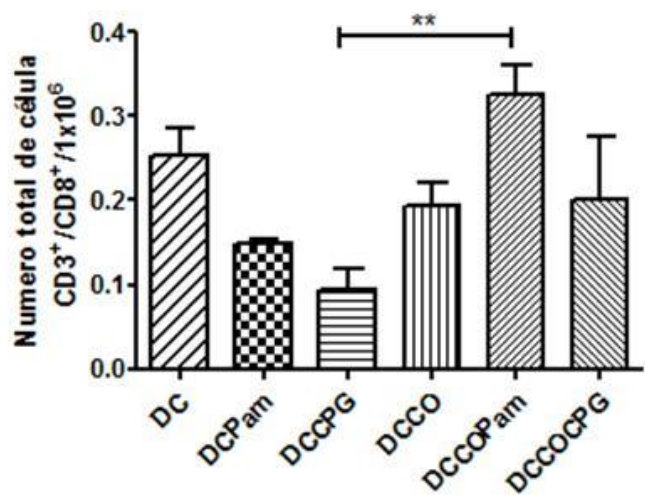

Linfonodo 30D HK

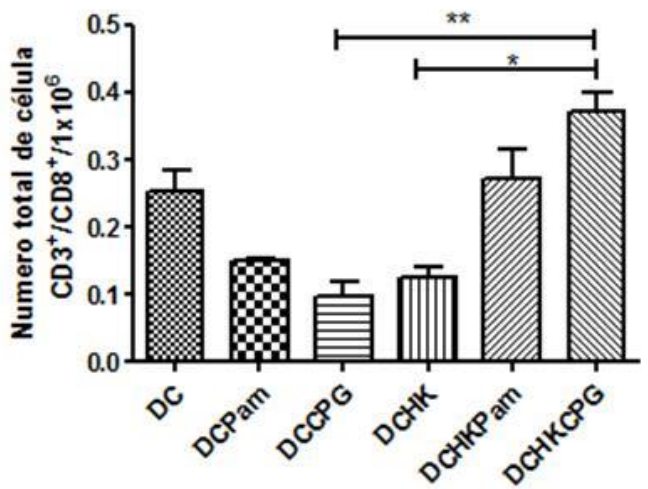

Figura 19. Análise fenotípica de células CD3+/CD8+ do linfonodo obtidas em experimento in vivo. Camundongos BALB/c ( 3 a 5 animais por grupo) foram divididos em 9 grupos e posteriormente, submetidos a inoculação, por via intramuscular, da seguinte forma: $1 \times 10^{6}$ de células dendríticas (DC), $1 \times 10^{6}$ de células dendríticas com agonista de via TLR2(Pam3CSK4) (DCPam), 1×10 de células dendríticas juntamente com agonista de TLR9 $(\mathrm{CpG})(\mathrm{DCCpG}), 1 \times 10^{7}$ de conídios de $F$. pedrosoi com $1 \times 10^{6}$ de células dendríticas (DCCO), $1 \times 10^{6}$ de células dendríticas com $1 \times 10^{7}$ de fungo morto por calor (DCHK), $1 \times 10^{6}$ de células dendríticas com $1 \times 10^{7}$ de conídio de $F$.

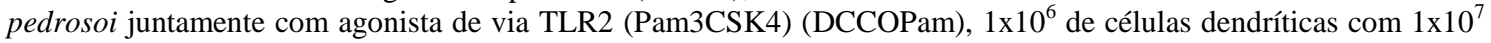
de conídio de $F$. pedrosoi morto por calor (HK) juntamente com agonista de via TLR2 (Pam3CSK4)(DCHKPam), $1 \times 10^{6}$ de células dendríticas com $1 \times 10^{7}$ de fungo morto por calor juntamente com agonista de via TLR9 (CpG) (DCHKCpG), ), $1 \times 10^{6}$ de células dendríticas com $1 \times 10^{7}$ de conídio de $F$. pedrosoi juntamente com agonista de via TLR9 (CpG) (DCCOCpG). Após 7 dias os camundongos foram submetidos a uma infecção intraperitoneal e eutanasiado ao trigésimo dia. As células foram então marcadas com anti- CD3/CD8 seguidos de counter 
plot com porcentagens de células. No gráfico de barra, cada barra representa a média +DP. Os dados são representativos do experimento $(* \mathrm{P}<0,05, * * \mathrm{P}<0,01)$.

Em resumo, os nossos dados mostraram que apenas a imunização com células dendríticas pulsadas com HK e o agonista CpG-ODN foi capaz de induzir o aumento de células TCD8 nos linfonodos após 30 dias de infecção.

\subsubsection{Caracterização de subpopulações de células $B$ nos linfonodos de camundongos infectados por 30 dias após tratamento com células dendríticas pulsadas com agonistas de TLR-2 e TLR-9.}

Investigamos o perfil de células B nos linfonodos poplíteos e inguinais após 30 dias de infecção, utilizando anticorpos anti-CD19, anti-B220 e anti-IgM, conforme Figura 23, conseguimos observar que o grupo controle (DC) teve uma ativação maior dessa classe de linfócitos quando comparado ao grupo DCCpG (células dendríticas interagidas com agonista de TLR-9) e uma diferença significativa quando comparada ao grupo DCCOCpG. Quando interagimos as células dendríticas com heat killed conseguimos perceber que tanto o grupo DCHK, quanto o grupo DCHKCpG tiveram uma diminuição significativa na ativação desses linfócitos. 

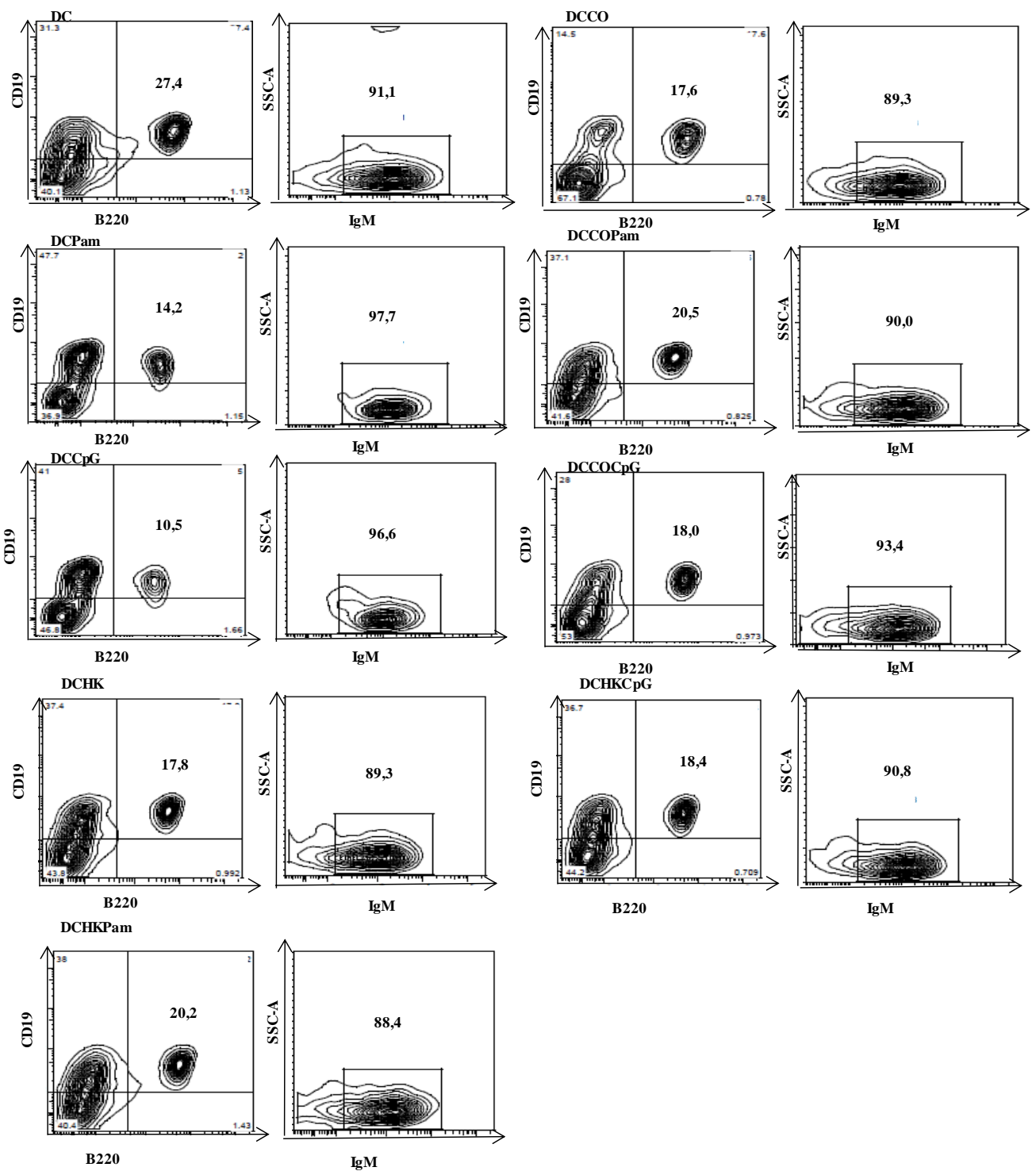

B220

IgM

Figura 170. Análise fenotípica de células B220+/CD19+ e IgM do linfonodo obtidas em experimento in vivo. Camundongos $\mathrm{BALB} / \mathrm{c}$ ( 3 a 5 animais por grupo) foram divididos em 9 grupos e posteriormente, submetidos a inoculação, por via intramuscular, da seguinte forma: $1 \times 10^{6}$ de células dendríticas (DC), $1 \times 10^{6}$ de células

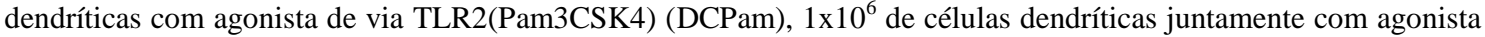
de TLR9 (CpG) (DCCpG), $1 \times 10^{7}$ de conídios de F. pedrosoi com $1 \times 10^{6}$ de células dendríticas (DCCO), $1 \times 10^{6}$ de

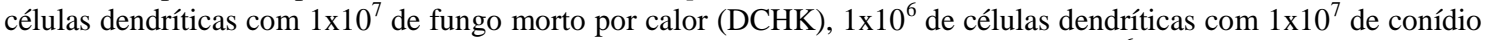
de $F$. pedrosoi juntamente com agonista de via TLR2 (Pam3CSK4) (DCCOPam), 1 1 $10^{6}$ de células dendríticas com $1 \times 10^{7}$ de conídio de $F$. pedrosoi morto por calor (HK) juntamente com agonista de via TLR2 (Pam3CSK4)(DCHKPam), $1 \times 10^{6}$ de células dendríticas com $1 \times 10^{7}$ de fungo morto por calor juntamente com agonista de via TLR9 (CpG) (DCHKCpG), ), $1 \times 10^{6}$ de células dendríticas com $1 \times 10^{7}$ de conídio de $F$. pedrosoi juntamente com agonista de via TLR9 (CpG) (DCCOCpG). Após 7 dias os camundongos foram submetidos a uma infecção intraperitoneal e eutanasiado ao trigésimo dia. As células foram então marcadas com anti- B220, anti-CD19, anti-IgM. 

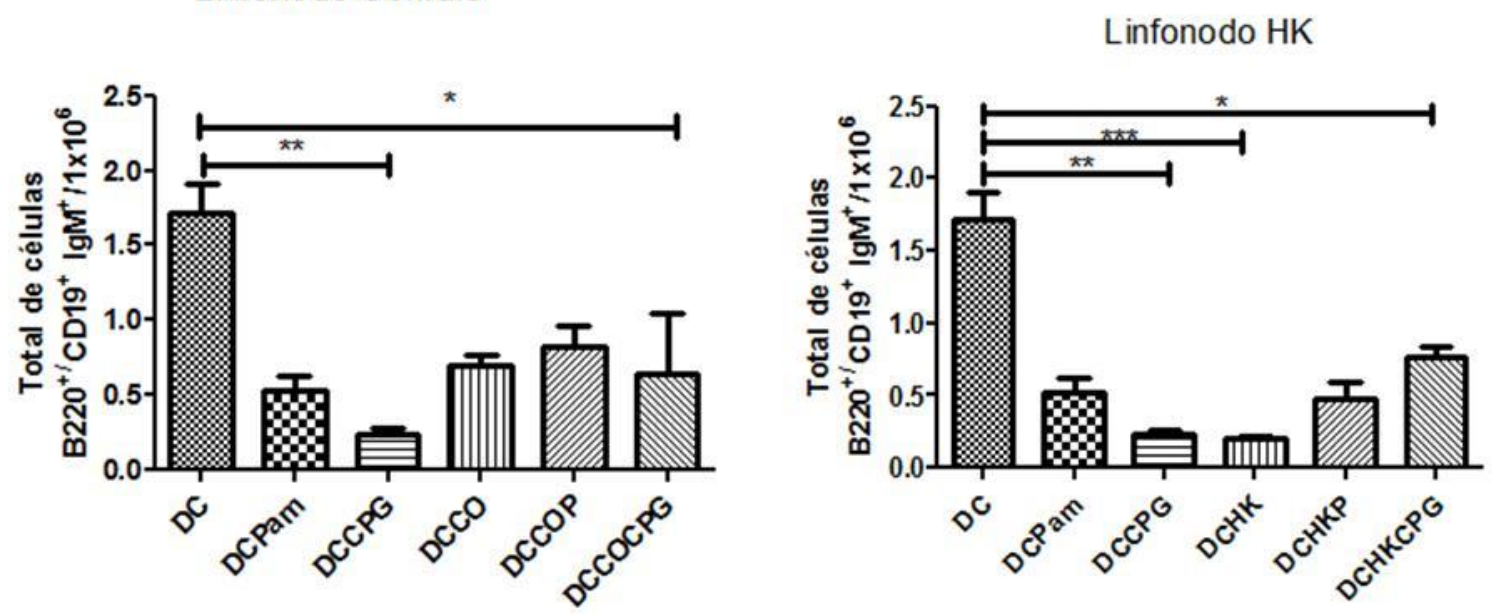

Figura 18. Análise fenotípica de células $\mathrm{B220+/CD19+} \mathrm{do} \mathrm{linfonodo} \mathrm{obtidas} \mathrm{em} \mathrm{experimento} \mathrm{in}$ vivo.Camundongos $\mathrm{BALB} / \mathrm{c}$ ( 3 a 5 animais por grupo) foram divididos em 9 grupos e posteriormente, submetidos a inoculação, por via intramuscular, da seguinte forma: $1 \times 10^{6}$ de células dendríticas (DC), 1×10 de células dendríticas com agonista de via TLR2(Pam3CSK4) (DCPam), 1×10 de células dendríticas juntamente com agonista de TLR9 $(\mathrm{CpG})(\mathrm{DCCpG}), 1 \times 10^{7}$ de conídios de $F$. pedrosoi com $1 \times 10^{6}$ de células dendríticas (DCCO), $1 \times 10^{6}$ de células dendríticas com $1 \times 10^{7}$ de fungo morto por calor (DCHK), $1 \times 10^{6}$ de células dendríticas com $1 \times 10^{7}$ de conídio de $F$.

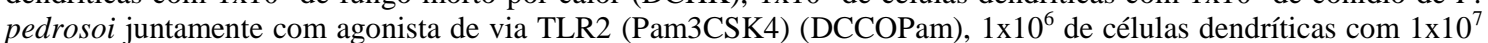
de conídio de $F$. pedrosoi morto por calor (HK) juntamente com agonista de via TLR2 (Pam3CSK4)(DCHKPam), $1 \times 10^{6}$ de células dendríticas com $1 \times 10^{7}$ de fungo morto por calor juntamente com agonista de via TLR9 (CpG) (DCHKCpG), ), $1 \times 10^{6}$ de células dendríticas com $1 \times 10^{7}$ de conídio de $F$. pedrosoi juntamente com agonista de via TLR9 (CpG) (DCCOCpG). Após 7 dias os camundongos foram submetidos a uma infecção intraperitoneal e eutanasiado ao trigésimo dia. As células foram então marcadas com anti- B220, anti-CD19. No gráfico de barra, cada barra representa a média $+\mathrm{DP}$. Os dados são representativos do experimento $(* \mathrm{P}<0,05$, $* * \mathrm{P}<0,01, * * * \mathrm{P}<0,001)$.

Em resumo, o perfil de células B com 30 dias não alteraram de forma promissora nos grupos com agonistas e fungo, quando comparado aos camundongos de tratamento controle, ou seja, apenas células dendríticas.

\subsubsection{Caracterização de moléculas de MHC-II nos linfonodos de camundongos infectados por 30 dias após tratamento com células dendríticas pulsadas com agonistas de TLR-2 e TLR-9.}

A importância das células dendríticas no foco primário da infecção por $F$. pedrosoi é de grande interesse, visto que essas células estão posicionadas estrategicamente para capturarem o antígeno, são altamente especializadas em fagocitar e processar microrganismos, para futuramente apresentar para o linfócito $\mathrm{T}$ "naive" (WICK,2003), após maturação dessas células. Na ausência de sinais inflamatórios ou infecção, as DC's possuem fenótipo caracterizado pela baixa expressão de molécula de 
MHC-II. Quando as células dendríticas são expostas a componentes derivados de patógenos, seu fenótipo sofre alteração com um aumento na expressão de moléculas de MHC-II (GUERMONPREZ et al., 2002). Conhecida essa importância, investigamos a expressão de moléculas MHC-II com o anticorpo anti-MHCII, para a quantificação dessa expressão.

Podemos notar que o grupo controle (DC) teve uma expressão aumentada significativamente quando comparada com o grupo DCCpG, DCHK e DCCOCpG, evidenciando que possivelmente o agonista de via TLR-9 não seja o mais indicado para um modelo profilático, conforme Figura 22 e 23. 


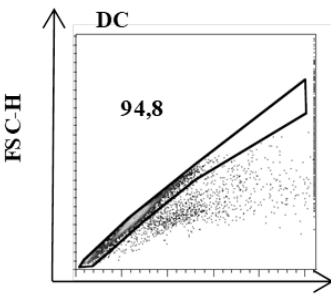

MHC-II

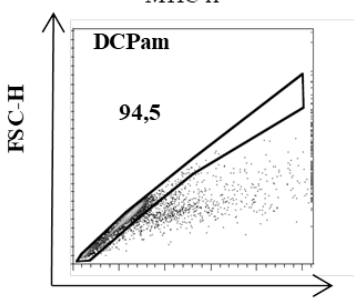

MHC-II

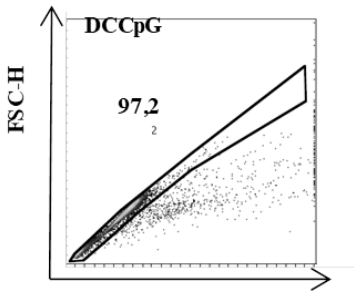

MHC-II

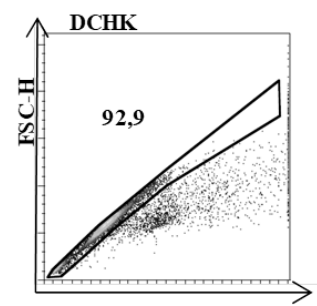

MHC-II

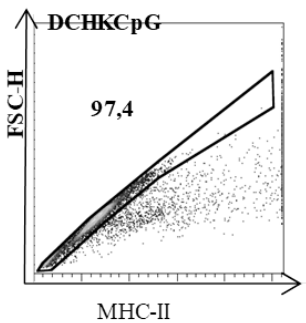

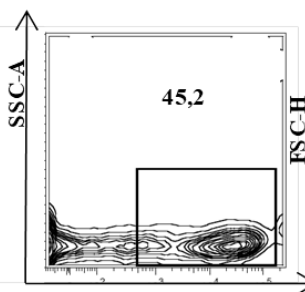

MHC-II

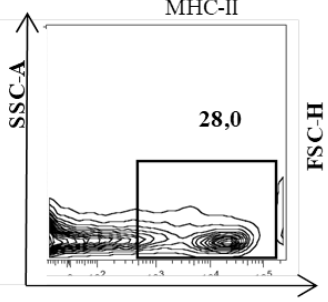

MHC-II
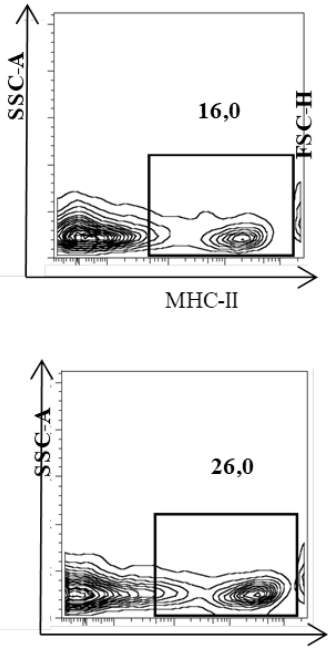

MHC-II

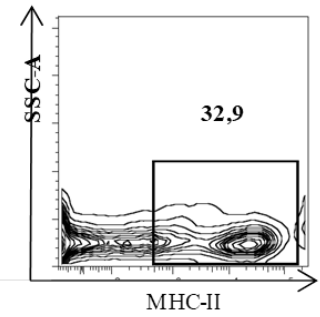

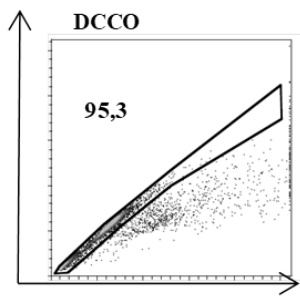

MHC-II

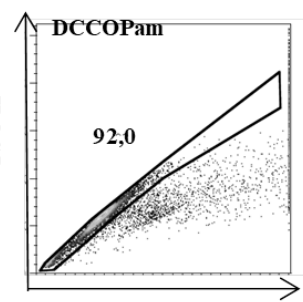

MHC-II

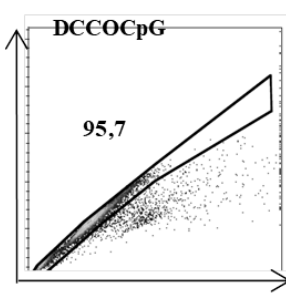

MHC-II

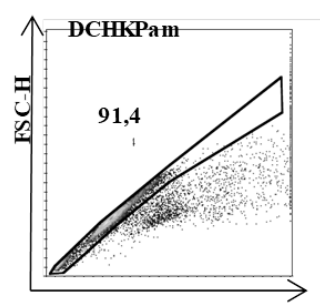

MHC-II

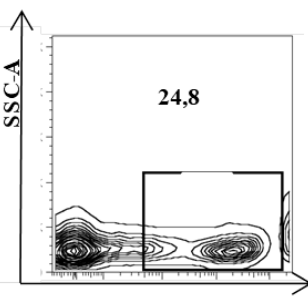

MHC-II

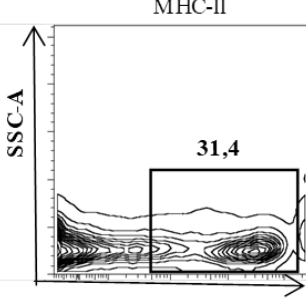

MHC-II

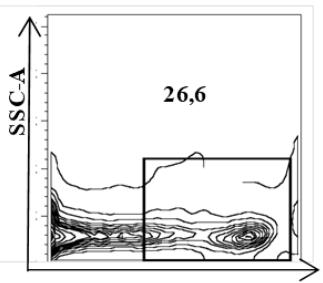

MHC-II

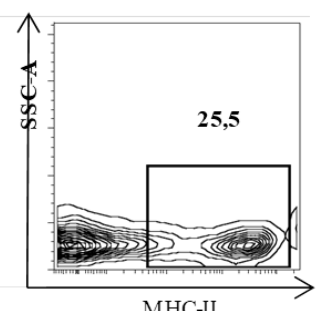

Figura 192. Análise fenotípica de células MHC-II+ do linfonodo obtidas em experimento in vivo. Camundongos BALB/c ( 3 a 5 animais por grupo) foram divididos em 9 grupos e posteriormente, submetidos a inoculação, por via intramuscular, da seguinte forma: $1 \times 10^{6}$ de células dendríticas (DC), $1 \times 10^{6}$ de células dendríticas com agonista de via TLR2(Pam3CSK4) (DCPam), $1 \times 10^{6}$ de células dendríticas juntamente com agonista de TLR9 (CpG) (DCCpG), $1 \times 10^{7}$ de conídios de $F$. pedrosoi com $1 \times 10^{6}$ de células dendríticas (DCCO), $1 \times 10^{6}$ de células dendríticas com $1 \times 10^{7}$ de fungo morto por calor (DCHK), $1 \times 10^{6}$ de células dendríticas com $1 \times 10^{7}$ de conídio de $F$.

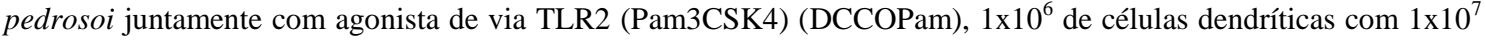
de conídio de $F$. pedrosoi morto por calor (HK) juntamente com agonista de via TLR2 (Pam3CSK4)(DCHKPam), $1 \times 10^{6}$ de células dendríticas com $1 \times 10^{7}$ de fungo morto por calor juntamente com agonista de via TLR9 (CpG) (DCHKCpG), ), $1 \times 10^{6}$ de células dendríticas com $1 \times 10^{7}$ de conídio de $F$. pedrosoi juntamente com agonista de via TLR9 (CpG) (DCCOCpG). Após 7 dias os camundongos foram submetidos a uma infecção intraperitoneal e eutanasiado ao trigésimo dia. As células foram então marcadas com anti- MHC-II. 

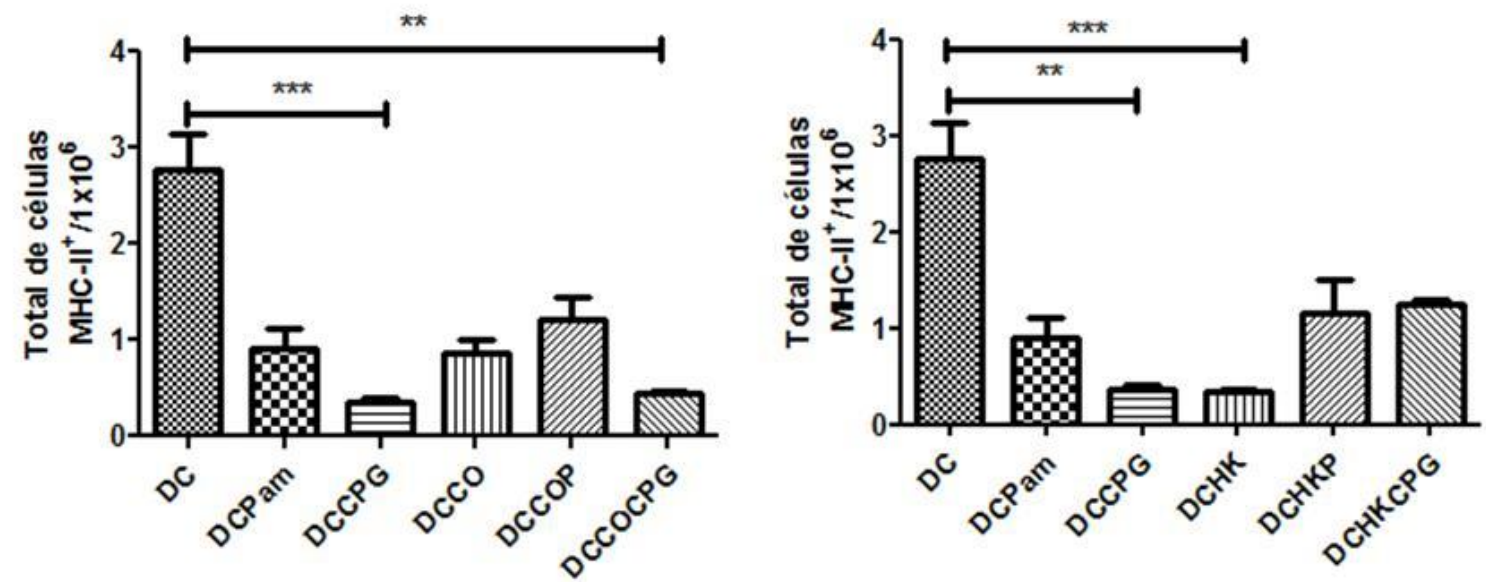

Figura 203. Análise fenotípica de células MHC-II+ do linfonodo obtidas em experimento in vivo. Camundongos BALB/c ( 3 a 5 animais por grupo) foram divididos em 9 grupos e posteriormente, submetidos a inoculação, por via intramuscular, da seguinte forma: $1 \times 10^{6}$ de células dendríticas (DC), $1 \times 10^{6}$ de células dendríticas com agonista de via TLR2(Pam3CSK4) (DCPam), 1×10 de células dendríticas juntamente com agonista de TLR9 $(\mathrm{CpG})(\mathrm{DCCpG}), 1 \times 10^{7}$ de conídios de $F$. pedrosoi com $1 \times 10^{6}$ de células dendríticas (DCCO), $1 \times 10^{6}$ de células dendríticas com $1 \times 10^{7}$ de fungo morto por calor (DCHK), $1 \times 10^{6}$ de células dendríticas com $1 \times 10^{7}$ de conídio de $F$.

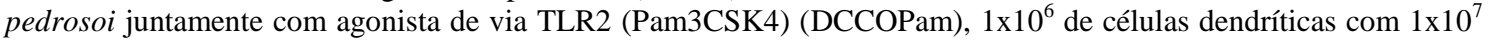
de conídio de $F$. pedrosoi morto por calor (HK) juntamente com agonista de via TLR2 (Pam3CSK4)(DCHKPam), $1 \times 10^{6}$ de células dendríticas com $1 \times 10^{7}$ de fungo morto por calor juntamente com agonista de via TLR9 (CpG) (DCHKCpG), ), $1 \times 10^{6}$ de células dendríticas com $1 \times 10^{7}$ de conídio de $F$. pedrosoi juntamente com agonista de via TLR9 (CpG) (DCCOCpG). Após 7 dias os camundongos foram submetidos a uma infecção intraperitoneal e eutanasiado ao trigésimo dia. As células foram então marcadas com anti- MHC-II. No gráfico de barra, cada barra representa a média $+\mathrm{DP}$. Os dados são representativos do experimento $(* * \mathrm{P}<0,01$, $* * * \mathrm{P}<0,001)$.

Em resumo, o tratamento com $\mathrm{CpG}$ e fungo vivo (DCCOCpG), diminuiram a expressão de MHC-II, assim como o grupo de Heat Killed (DCHK).

\subsection{Unidades Formadoras de Colônias}

Para avaliar o papel modulatório de TLR-2 e TLR-9 no curso da doença, camundongo Balb/c foram tratados e infectados após 7 dias, o baço e fígado dos animais foram retirados para análise de UFC. Observamos que não houve uma diferença estatística entre os diferentes grupos tratados.

No grupo tratado por sete dias e infectado por sete dias, não houve o crescimento de colônias em nenhum dos grupos, conforme Figuras 24 e 25. 
Baço 7 Dias Conidio

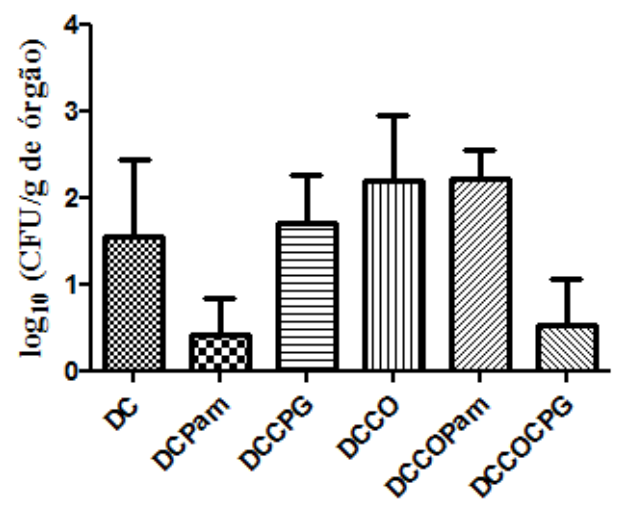

Baço 7 Dias HK

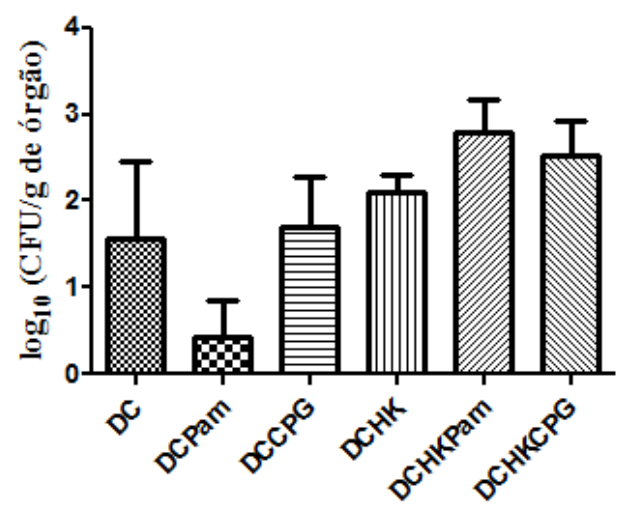

Figura 2421. Unidades formadoras de colônias do baço de camundongos BALB/c infectados com $10^{6}$ de conídios de $\boldsymbol{F}$. pedrosoi na presença ou ausência de PAM3CSK4 e CpG, por 7 dias. Camundongos BALB/c (3 a 5 animais por grupo) foram divididos em 9 grupos e posteriormente, submetidos a inoculação, por via intramuscular, da seguinte forma: $1 \times 10^{6}$ de células dendríticas (DC), $1 \times 10^{6}$ de células dendríticas com agonista de via TLR2(Pam3CSK4) (DCPam), 1 $\times 10^{6}$ de células dendríticas juntamente com agonista de TLR9 (CpG) (DCCpG), $1 \times 10^{7}$ de conídios de $F$. pedrosoi com $1 \times 10^{6}$ de células dendríticas (DCCO), $1 \times 10^{6}$ de células dendríticas com $1 \times 10^{7}$ de fungo morto por calor (DCHK), $1 \times 10^{6}$ de células dendríticas com $1 \times 10^{7}$ de conídio de $F$. pedrosoi juntamente com

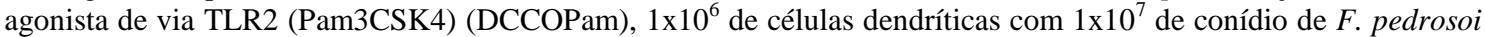
morto por calor (HK) juntamente com agonista de via TLR2 (Pam3CSK4)(DCHKPam), 1 $10^{6}$ de células dendríticas com $1 \times 10^{7}$ de fungo morto por calor juntamente com agonista de via TLR9 (CpG) (DCHKCpG), ), 1x10 ${ }^{6}$ de células dendríticas com $1 \times 10^{7}$ de conídio de F. pedrosoi juntamente com agonista de via TLR9 (CpG) (DCCOCpG). Após 7 dias os camundongos foram submetidos a uma infecção intraperitoneal e eutanasiados no trigésimo dia. No gráfico de barra, cada barra representa a média +DP. Os dados são representativos do experimento (NS).

Fígado 7 Dias Conídio

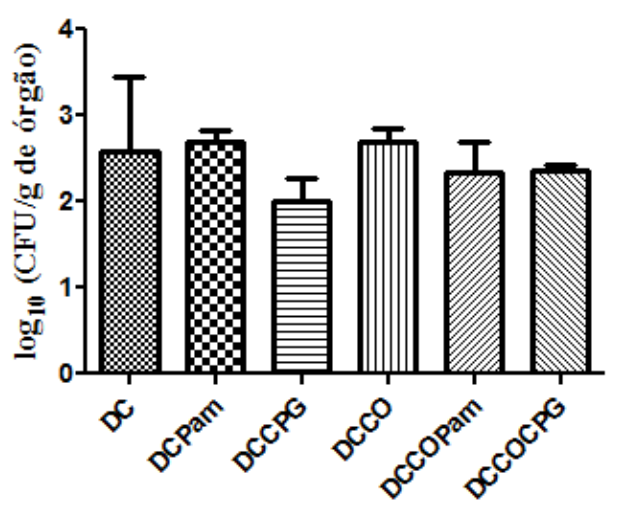

Fígado 7 Dias HK

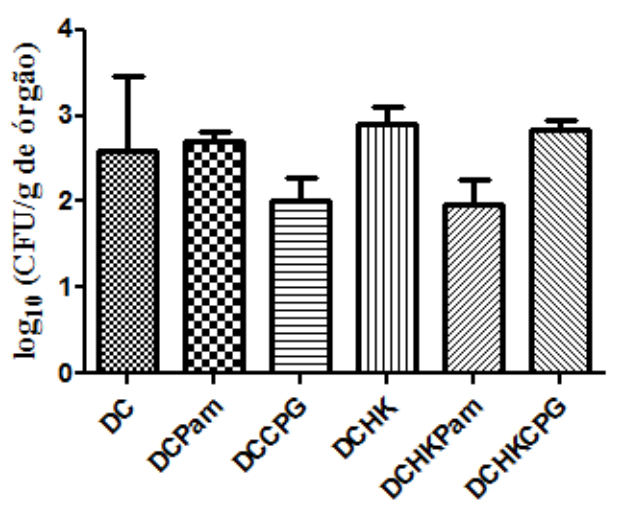

Figura 25. Unidades formadoras de colônias do fígado de camundongos BALB/c infectados com $10^{6}$ de conídios de $\boldsymbol{F}$. pedrosoi na presença ou ausência de PAM3CSK4 e CpG, por 7 dias Camundongos BALB/c (3 a 5 animais por grupo) foram divididos em 9 grupos e posteriormente, submetidos a inoculação, por via intramuscular, da seguinte forma: $1 \times 10^{6}$ de células dendríticas (DC), $1 \times 10^{6}$ de células dendríticas com agonista de via TLR2(Pam3CSK4) (DCPam), 1 1 $10^{6}$ de células dendríticas juntamente com agonista de TLR9 (CpG) (DCCpG), $1 \times 10^{7}$ de conídios de $F$. pedrosoi com $1 \times 10^{6}$ de células dendríticas (DCCO), $1 \times 10^{6}$ de células dendríticas com $1 \times 10^{7}$ de fungo morto por calor (DCHK), $1 \times 10^{6}$ de células dendríticas com $1 \times 10^{7}$ de conídio de $F$. pedrosoi juntamente com agonista de via TLR2 (Pam3CSK4) (DCCOPam), $1 \times 10^{6}$ de células dendríticas com $1 \times 10^{7}$ de conídio de $F$. pedrosoi morto por calor (HK) juntamente com agonista de via TLR2 (Pam3CSK4)(DCHKPam), 1x10 ${ }^{6}$ de células dendríticas com $1 \times 10^{7}$ de fungo morto por calor juntamente com agonista de via TLR9 (CpG) (DCHKCpG), ), 1×10 de células dendríticas com $1 \times 10^{7}$ de conídio de F. pedrosoi juntamente com agonista de via TLR9 (CpG) (DCCOCpG). Após 7 dias os camundongos foram submetidos a uma infecção intraperitoneal e eutanasiados no trigésimo dia. No gráfico de barra, cada barra representa a média +DP. Os dados são representativos do experimento (NS) 


\section{CAPÍtUlO II}

\section{Análise da evolução da cromoblastomicose (CBM) murina após} tratamento com células dendríticas pulsadas com conídios vivos de F.pedrosoi e agonista de TLR2.

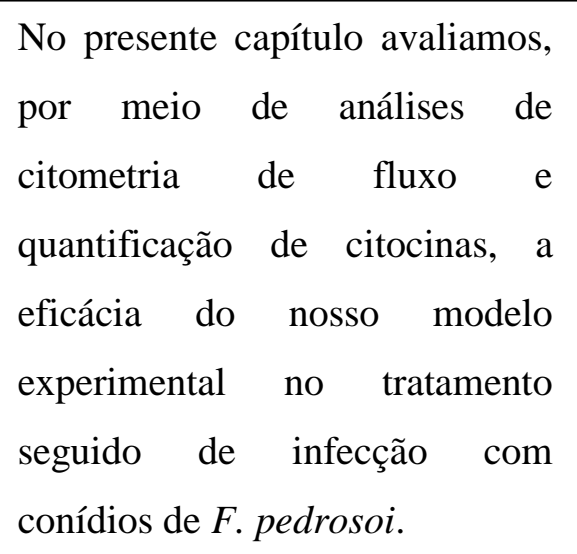




\section{Desenho experimental}

Experimentos anteriores nos possibilitaram a observar que o Heat Killed e o agonista de via TLR9 não demonstraram um papel eficaz no nosso modelo experimental, assim sendo no presente capítulo focamos nos experimentos in vivo com o fungo vivo e agonista de TLR2.

\section{Tratamento- IM}

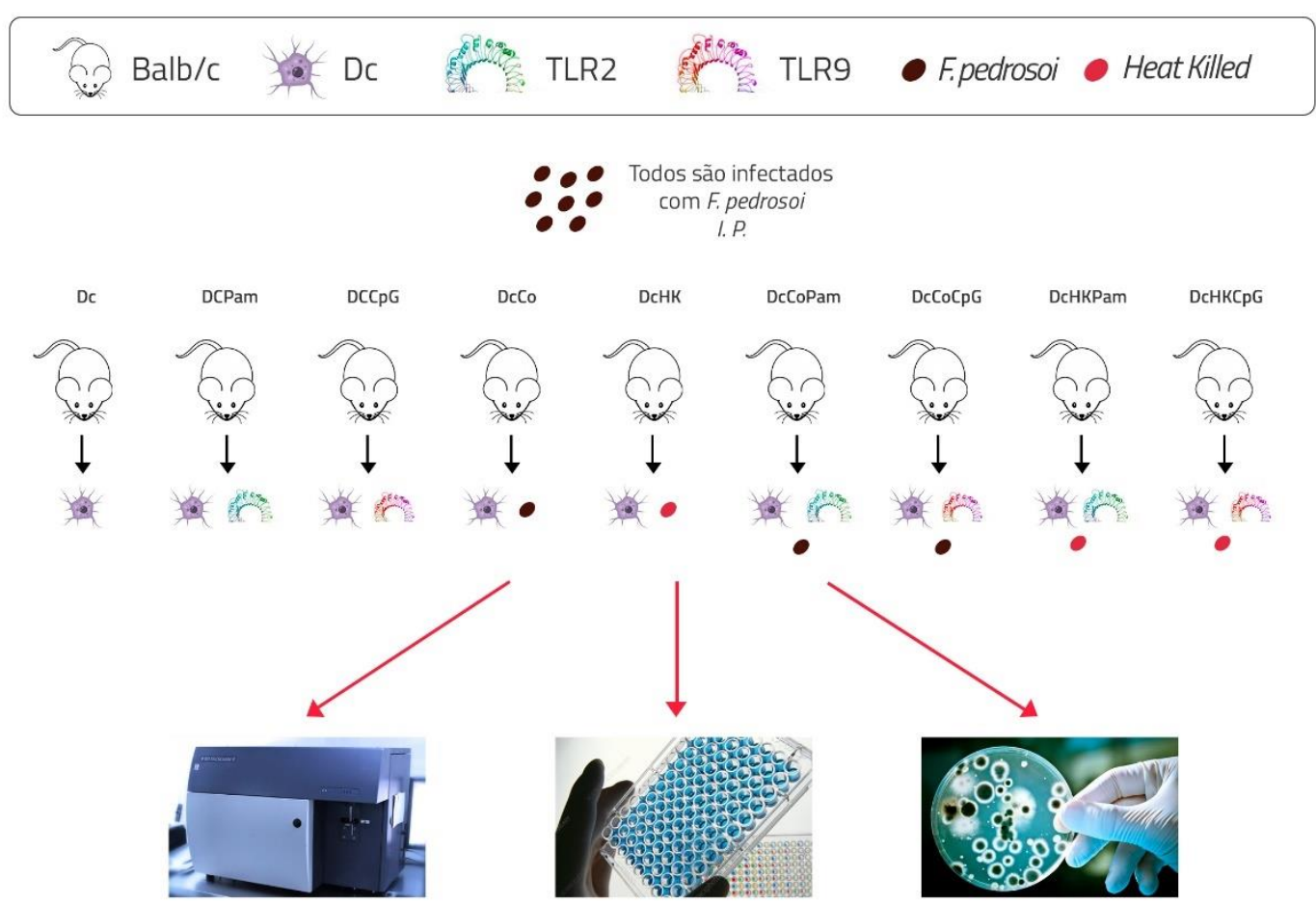

Figura 26. Esquema de imunização dos animais com DCs pulsadas com Fonsecaea pedrosoi

\section{Resultados}

\subsection{Citometria de Fluxo}

Com o objetivo de investigar o perfil de células $\mathrm{T}$ e $\mathrm{B}$ presentes no baço e linfonodos poplíteos e inguinais, após os animais passarem por imunização intramuscular na região das coxas, seguidas de uma infecção com conídios de $F$. pedrosoi por via intraperitoneal, estes foram eutanasiados e as células totais foram utilizadas para marcação com anticorpos específicos. 
Os anticorpos utilizados na Imunofenotipagem, pelo método de Citometria de Fluxo, foram anti-CD3 PE, anti-CD4 PERCPCY5, anti-CD8 PECY7, anti-CD19(APC) anti-CD45R e anti-IgM, onde avaliou-se as porcentagens de linfócitos TCD4 (CD3 ${ }^{+}$ $\left.\mathrm{CD}^{+}\right)$, TCD8 $\left(\mathrm{CD}^{+} \mathrm{CD}^{+}\right)$e linfócitos B $\left(\mathrm{B} 220^{+}, \mathrm{CD}-19^{+}, \mathrm{CD}-45^{+}, \mathrm{IgM}^{+)}\right.$no baço e linfonodo dos animais tratados nos diferentes grupos utilizados nesse trabalho.

\subsubsection{Caracterização de subpopulações de células $\mathbf{T}$ no baço e no linfonodo de camundongos infectados por 15 dias após tratamento com células dendríticas pulsadas com agonista de TLR-2.}

Após 7 dias de tratamento os camundongos foram submetidos à infecção com $1 \times 10^{7}$ de conídio de $F$. pedrosoi por 15 dias. Ao décimo quinto dia os camundongos foram eutanasiados em conformidade com a Comissão de Ética no Uso de Animais (CEUA), baço e linfonodo foram retirados e macerados na presença de PBS estéril.

Nossos grupos de tratamento foram divididos em 4, o grupo controle tratado somente com células dendríticas (Dc), o grupo tratado com células dendríticas e agonista de TLR2 (Pam3CSK4) (DCPam), tratados com conídios de F. pedrosoi (DCCO) e por último o grupo tratado com células dendríticas sensibilizadas com conídios de $F$. pedrosoi e agonista de TLR2 (DCCOPam).

Ao realizar análise observamos que o grupo tratado somente com conídios de $F$. pedrosoi (DCCO) apresentou uma quantidade de células $\mathrm{TCD}^{+}$maior quando comparada ao grupo tratado com o nosso controle, ou seja, somente células dendríticas (Dc).

Sabe-se que a gravidade da cromoblastomicose está ligada a uma resposta celular Th1 ineficiente, assim a ausência de linfócitos $\mathrm{TCD}^{+}$é determinante para a gravidade da doença em comparação aos linfócitos $\mathrm{TCD}^{+}$, conforme demonstrado por TEIXEIRA e colaboradores (2006) a depleção em camundongos C57BL/6 de células $\mathrm{TCD}^{+}{ }^{+}$induziu uma depressão da resposta imune celular e uma doença mais grave, enquanto a ausência de células $\mathrm{TCD}^{+}$não alterou a infecção, assim sendo pelos atuais dados obtidos no baço desses animais podemos observar que o grupo tratado com os conídios de $F$. pedrosoi tem um perfil fenotípico maior em TCD4 (Figura 27). Esses resultados serão observados como promissores posteriormente com a dosagem de citocinas. 
Nos linfonodos desses animais tratados, infectado e eutanasiados, conseguimos observar que o grupo tratado com células dendríticas interagidas com agonista de TLR2 (DCPam) apresentou um perfil fenotípico maior para TCD4 e TCD8, quando comparado aos outros grupo de tratamento, evidenciando uma possível formação de resposta imunológica desenvolvida com a participação mais sensível do receptor do tipo TLR2 (Figura 28).
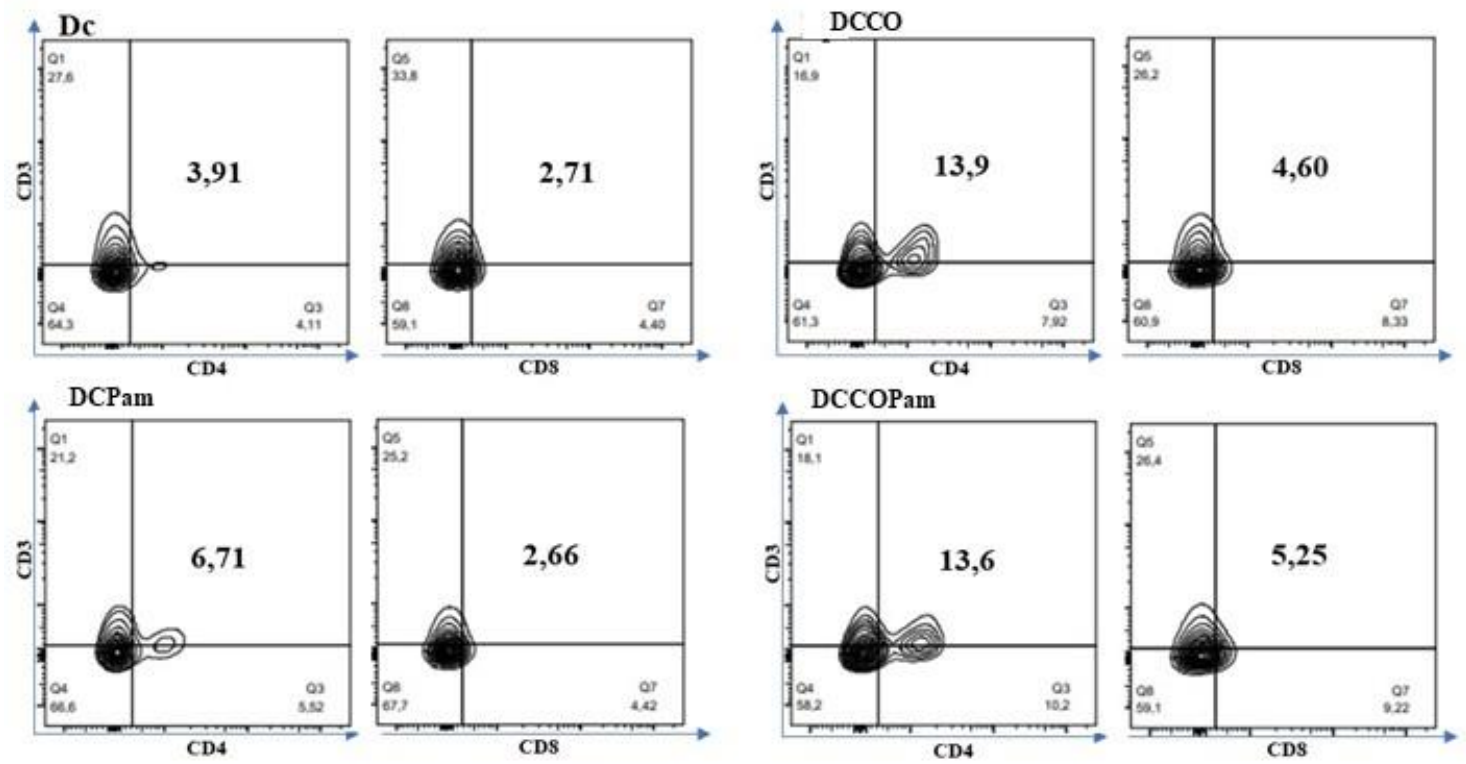

Baço - 15 dias
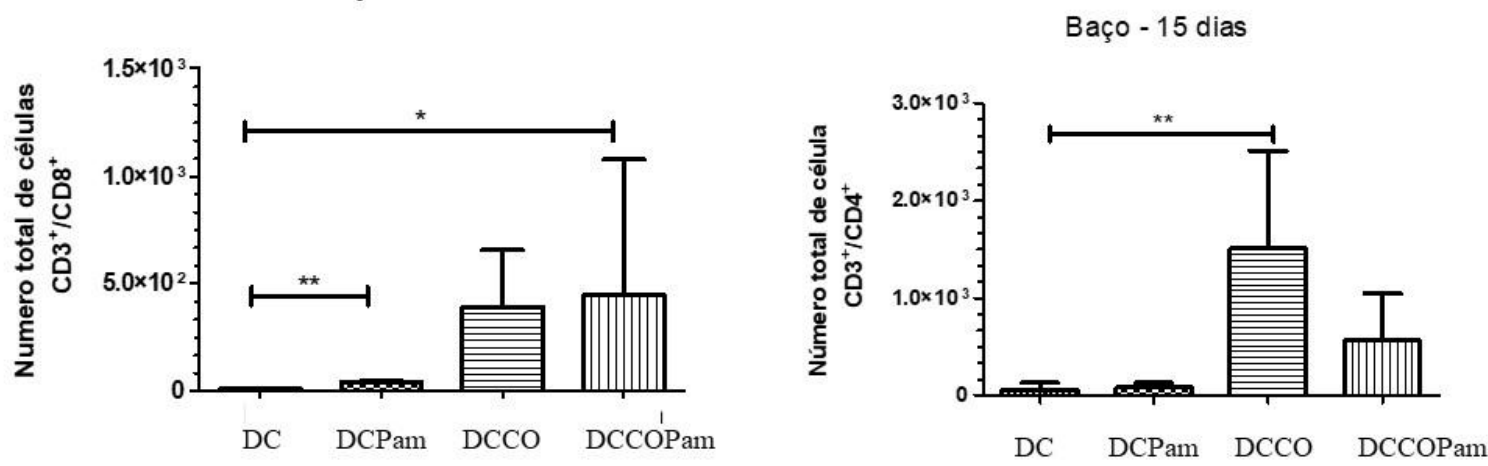

Figura 27. Análise fenotípica de células CD3+/CD4+ CD3+/CD8+ do baço obtidas em experimento in vivo. Camundongos BALB/c (4 ou 5 animais por grupo) foram divididos em 4 grupos e posteriormente, submetidos a inoculação, por via intramuscular, da seguinte forma: $1 \times 10^{6}$ de células dendríticas (DC), $1 \times 10^{6}$ de células dendríticas com agonista de via TLR2(Pam3CSK4) (DCPam), $1 \times 10^{7}$ de conidios de F. pedrosoi com 1 $10^{6}$ de células dendríticas (DCCO), $1 \times 10^{6}$ de células dendriticas com $1 \times 10^{7}$ de conídio de $F$. pedrosoi juntamente com agonista de via TLR2 (Pam3CSK4) (DCCOPam).Após 7 dias os camundongos foram submetidos a uma infecção intraperitoneal e eutanasiado ao décimo quinto dia. As células foram então marcadas com anti- CD3/CD4 e anti-CD3/CD8. No gráfico de barra, cada barra representa a média $+\mathrm{DP}$. Os dados são representativos do experimento $(* \mathrm{P}<0,05, * * \mathrm{P}<0,01)$. 
Em resumo, podemos observar que em comparação ao grupo controle DCCO, o tratamento com o agonista Pam3CSK4 (DCCOPam) não induziu um aumento significativo de células $\mathrm{T}$ no baço após 15 dias de infecção. Porém, observamos um aumento significativo em células $\mathrm{TCD}^{+}$quando as células dendríticas foram pulsadas $\begin{array}{llll}\text { apenas com } \text { conídios } & \text { de pedrosoi. }\end{array}$
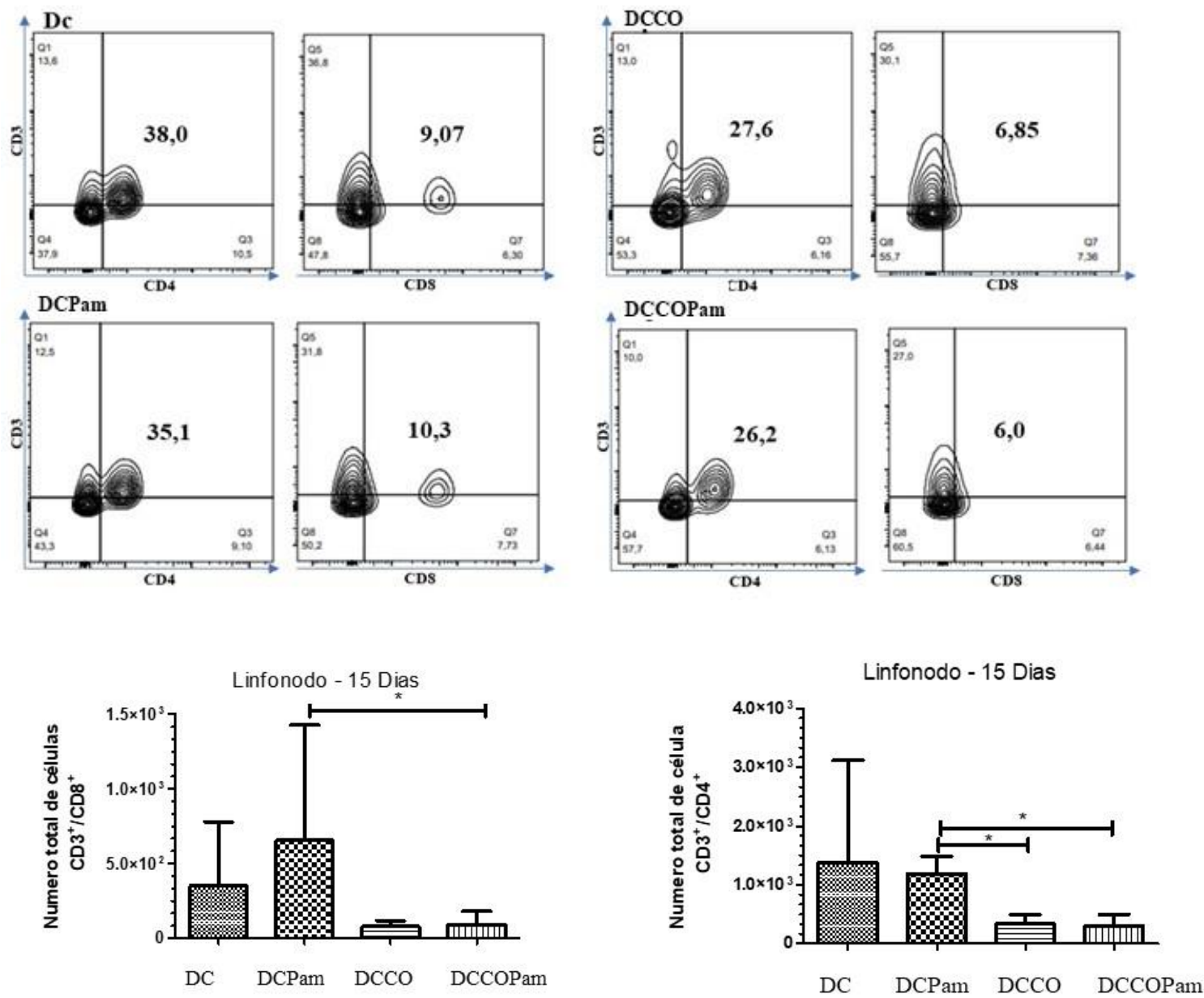

Figura 28. Análise fenotípica de células CD3+/CD4+ CD3+/CD8+ do linfonodo obtidas em experimento in vivo. Camundongos $\mathrm{BALB} / \mathrm{c}$ (4 ou 5 animais por grupo) foram divididos em 4 grupos e posteriormente, submetidos a inoculação, por via intramuscular, da seguinte forma: $1 \times 10^{6}$ de células dendríticas (DC), $1 \times 10^{6}$ de células dendríticas com agonista de via TLR2(Pam3CSK4) (DCPam), $1 \times 10^{7}$ de conidios de $F$. pedrosoi com $1 \times 10^{6}$ de células dendríticas (DCCO), $1 \times 10^{6}$ de células dendriticas com $1 \times 10^{7}$ de conídio de $F$. pedrosoi juntamente com agonista de via TLR2 (Pam3CSK4) (DCCOPam).Após 7 dias os camundongos foram submetidos a uma infecção intraperitoneal e eutanasiado ao décimo quinto dia.. As células foram então marcadas com anti- CD3/CD4 e anti-CD3/CD8. No gráfico de barra, cada barra representa a média +DP. Os dados são representativos do experimento $(* \mathrm{P}<0,05)$.

Em resumo, podemos observar que a presença do conídio de $F$. pedrosoi no tratamento com agonista de TLR2 diminui estatisticamente as células TCD4 ${ }^{+}$e TCD8 ${ }^{+}$ no linfonodo de camundongos infectados por 15 dias. 


\subsubsection{Caracterização de subpopulações de células B no baço e linfonodo de camundongos infectados por 15 dias após tratamento com células dendríticas pulsadas com agonista de TLR-2.}

O desenvolvimento da resposta imune a antígenos pode depender da interação entre células B e células T. Assim como as células apresentadoras profissionais de antígenos macrófagos e células dendríticas, os linfócitos B maduros também desempenham papel crucial na imunidade como células apresentadoras de antígenos, essas células podem ativar linfócitos TCD4 efetores e, ampliar as respostas por células T, manifestando assim o seu potencial patogênico (YU et al., 2006).

Considerando o papel dos linfócitos B no sistema imune, observamos o perfil dessas células envolvidas na infecção experimental com F. Pedrosoi. Após 15 dias de infecção as células obtidas do baço e linfonodos foram analisadas por citometria de fluxo evidenciando uma presença maior de células B nos camundongos do grupo tratado com conídios de F. pedrosoi (DCCO) quando nos referimos ao baço.

Recentemente tem sido destacado o potencial dos LB em desempenhar suas funções após ativação de outros receptores relacionados à resposta imune inata, tais como os Toll-Like Receptors (TLRs). Foi demonstrado que os LB expressam a maioria dos TLRs, tais como TLR-2, TLR-3, TLR-5 TLR-7 e TLR-9, respondendo a uma enorme variedade de ligantes que podem ser proteicos, polissacarídicos, lipídicos e outros (Gray D et al., 2007). Ao observarmos o grupo de tratamento DCPam dos linfonodos, conseguimos perceber que a presença de linfócitos B se deu muito mais nesse órgão e grupo, quando comparado a qualquer outro. 

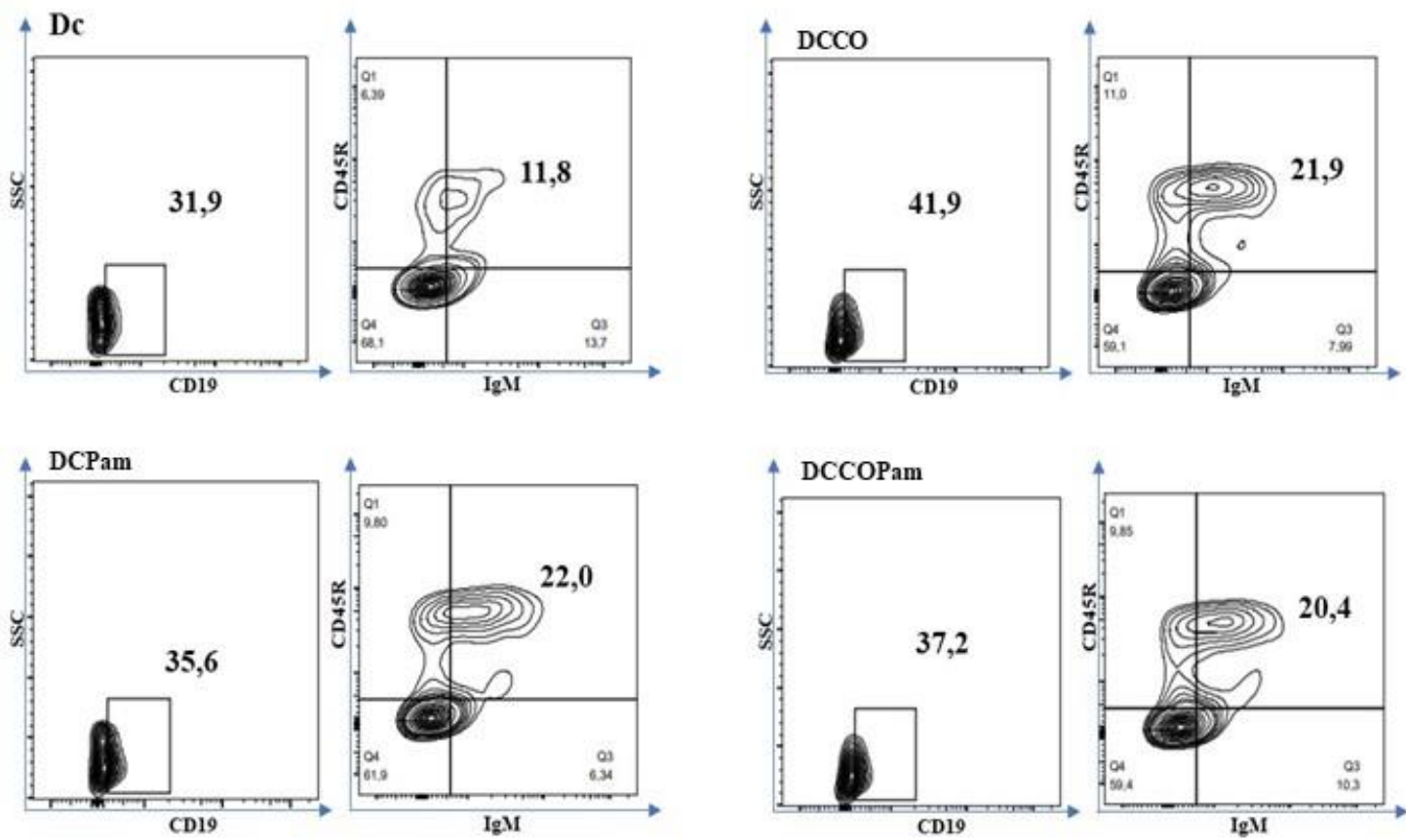

Baço - 15 dias

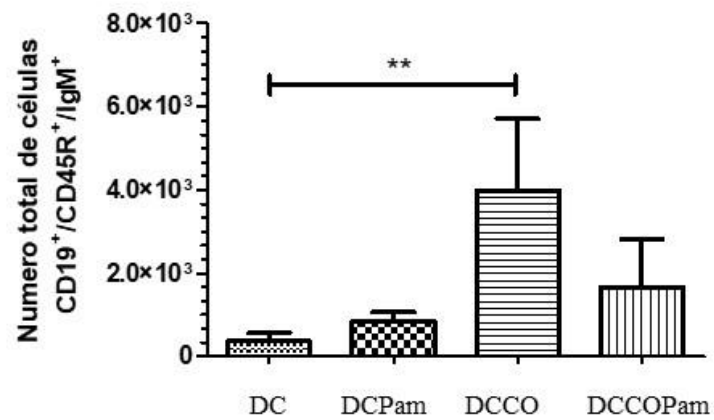

Figura 29. Análise fenotípica de células CD19+/CD45R+ IgM+ do baço obtidas em experimento in vivo. Camundongos BALB/c (4 ou 5 animais por grupo) foram divididos em 4 grupos e posteriormente, submetidos a inoculação, por via intramuscular, da seguinte forma: $1 \times 10^{6}$ de células dendríticas (DC), $1 \times 10^{6}$ de células dendríticas com agonista de via TLR2(Pam3CSK4) (DCPam), $1 \times 10^{7}$ de conidios de $F$. pedrosoi com $1 \times 10^{6}$ de células dendríticas (DCCO), $1 \times 10^{6}$ de células dendriticas com $1 \times 10^{7}$ de conídio de $F$. pedrosoi juntamente com agonista de via TLR2 (Pam3CSK4) (DCCOPam).Após 7 dias os camundongos foram submetidos a uma infecção intraperitoneal e eutanasiado ao décimo quinto dia. As células foram então marcadas com anti-CD19 anti-CD45R e anti-IgM. No gráfico de barra, cada barra representa a média $+\mathrm{DP}$. Os dados são representativos do experimento $(* * \mathrm{P}<0,01)$. 

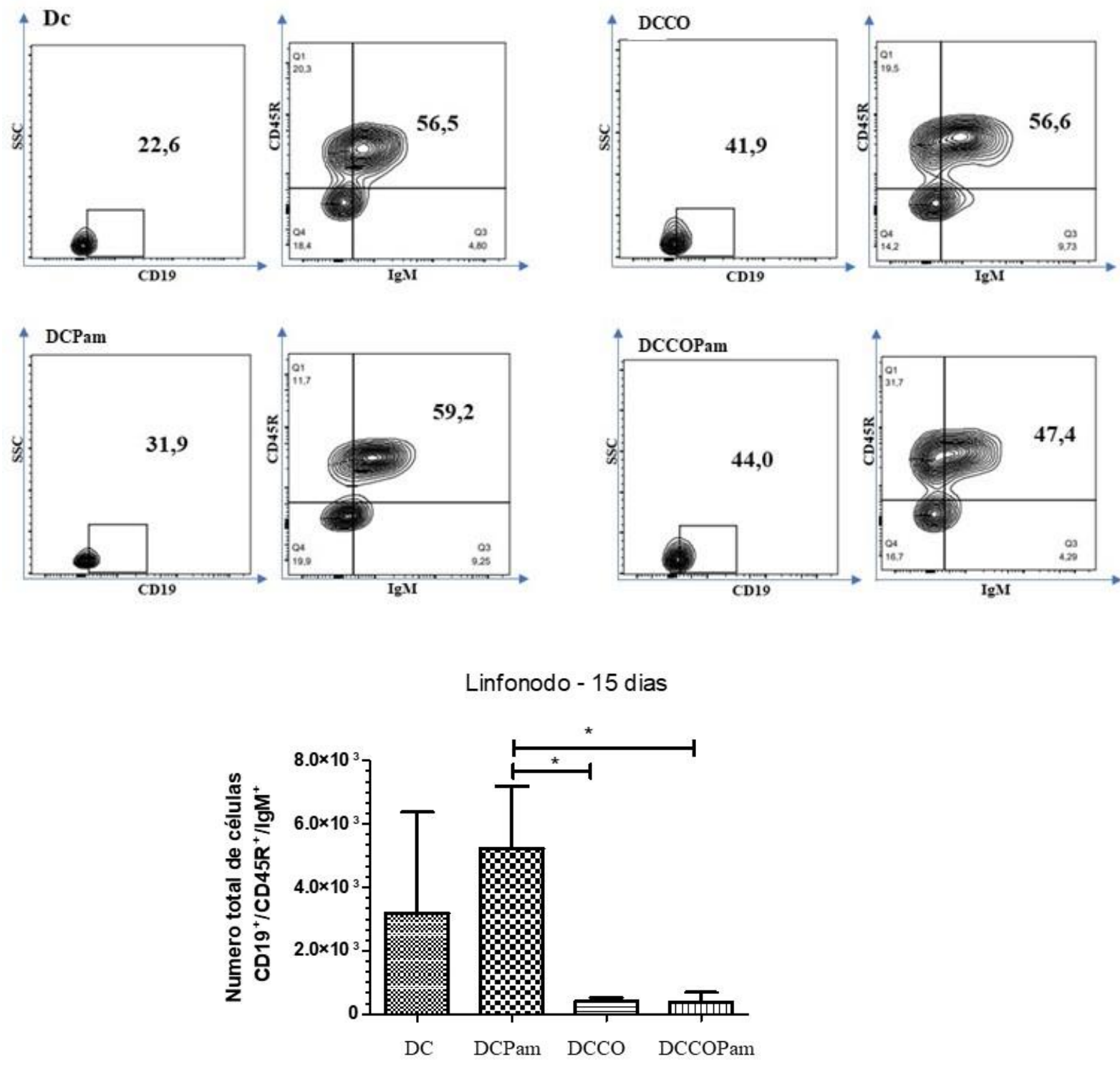

Figura 30. Análise fenotípica de células CD19+/CD45R+ IgM+ do linfonodo obtidas em experimento in vivo Camundongos BALB/c (4 ou 5 animais por grupo) foram divididos em 4 grupos e posteriormente, submetidos a inoculação, por via intramuscular, da seguinte forma: $1 \times 10^{6}$ de células dendríticas (DC), $1 \times 10^{6}$ de células dendríticas com agonista de via TLR2(Pam3CSK4) (DCPam), $1 \times 10^{7}$ de conidios de $F$. pedrosoi com $1 \times 10^{6}$ de células dendríticas (DCCO), $1 \times 10^{6}$ de células dendriticas com $1 \times 10^{7}$ de conídio de $F$. pedrosoi juntamente com agonista de via TLR2 (Pam3CSK4) (DCCOPam).Após 7 dias os camundongos foram submetidos a uma infecção intraperitoneal e eutanasiado ao décimo quinto dia. As células foram então marcadas com anti-CD19 anti-CD45R e anti-IgM. No gráfico de barra, cada barra representa a média +DP. Os dados são representativos do experimento $(* \mathrm{P}<0,05)$.

Em resumo, o grupo DCPam induziu uma presença maior de células B no linfonodo de camundongos infectados por 15 dias, quando comparado ao grupo tratado com conídios de $F$. pedrosoi e agonista de TLR2 (DCCOPam). 


\subsubsection{Caracterização de subpopulações de células $\mathbf{T}$ no baço $\mathrm{e}$ no linfonodo de camundongos infectados por 30 dias após tratamento com células dendríticas pulsadas com agonista de TLR-2.}

Considerando o papel dos linfócitos T CD4 e T CD8 no sistema imune, observamos o perfil dessas células envolvidas na infecção experimental com F. pedrosoi.

O grupo tratado com $F$. pedrosoi interagido com células sensibilizadas com o agonista de TLR2 (DCCOPam) demonstraram uma presença maior de células com perfil TCD4 no baço dos camundongos quando comparado ao grupo controle (Figura 31).

Já nos linfonodos podemos observar que os grupos tratados com o agonista de TLR2 com ou sem conídios de $F$. pedrosoi possui uma tendência no aumento de células TCD4 e TCD8, porém os dados não se apresentam de forma significativa (Figura 32).
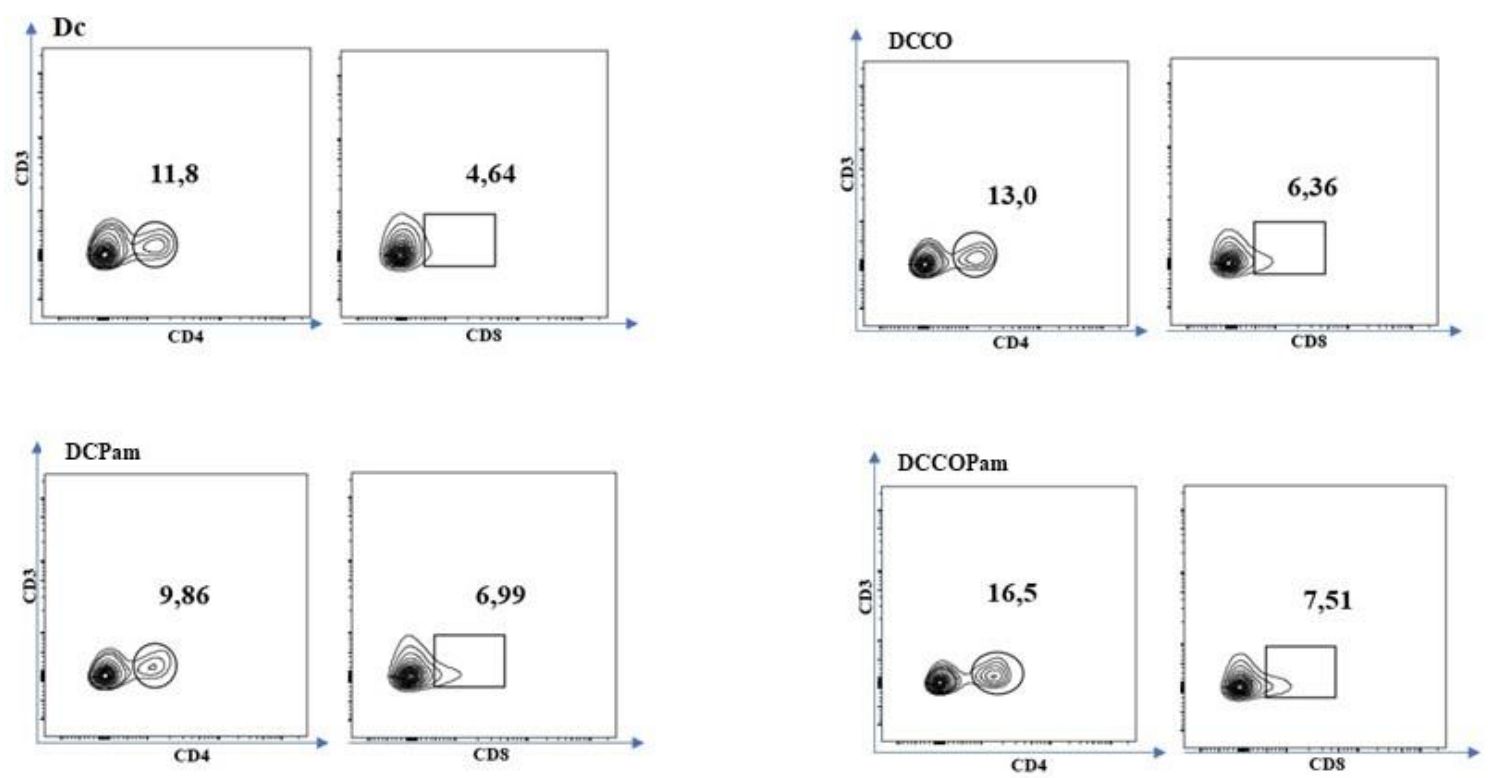

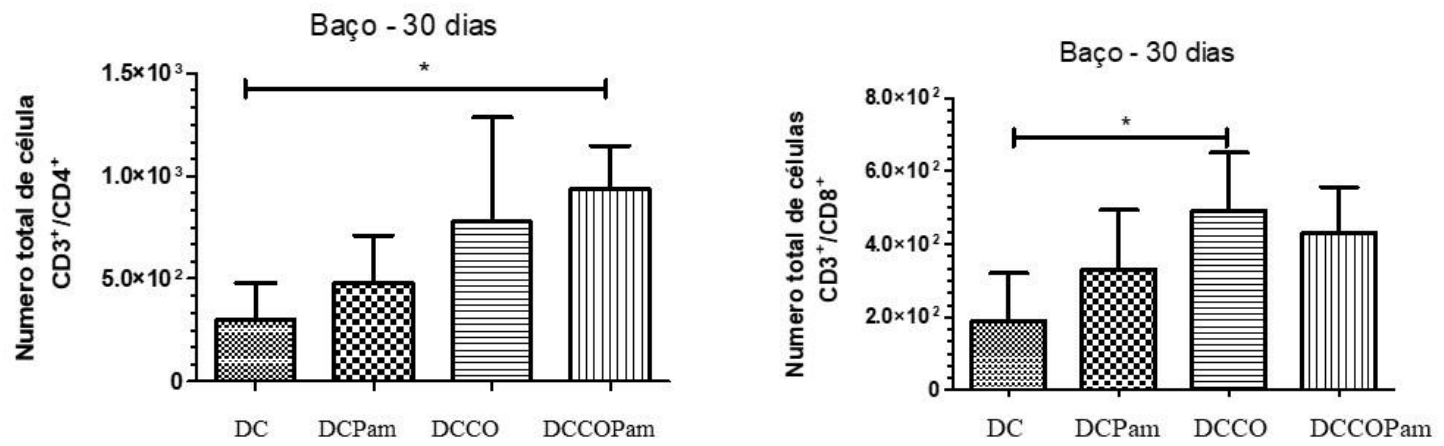

Figura 31. Análise fenotípica de células CD3+/CD4+ CD3+/CD8+ do baço obtidas em experimento in vivo. Camundongos BALB/c (4 ou 5 animais por grupo) foram divididos em 4 grupos e posteriormente, submetidos a inoculação, por via intramuscular, da seguinte forma: $1 \times 10^{6}$ de células dendríticas (DC), $1 \times 10^{6}$ de

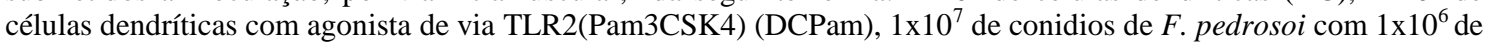
células dendríticas (DCCO), $1 \times 10^{6}$ de células dendriticas com $1 \times 10^{7}$ de conídio de $F$. pedrosoi juntamente com agonista de via TLR2 (Pam3CSK4) (DCCOPam).Após 7 dias os camundongos foram submetidos a uma infecção intraperitoneal e eutanasiado ao décimo quinto dia. As células foram então marcadas com anti- CD3/CD4 e antiCD3/CD8. No gráfico de barra, cada barra representa a média +DP. Os dados são representativos do experimento $(* \mathrm{P}<0,05)$.
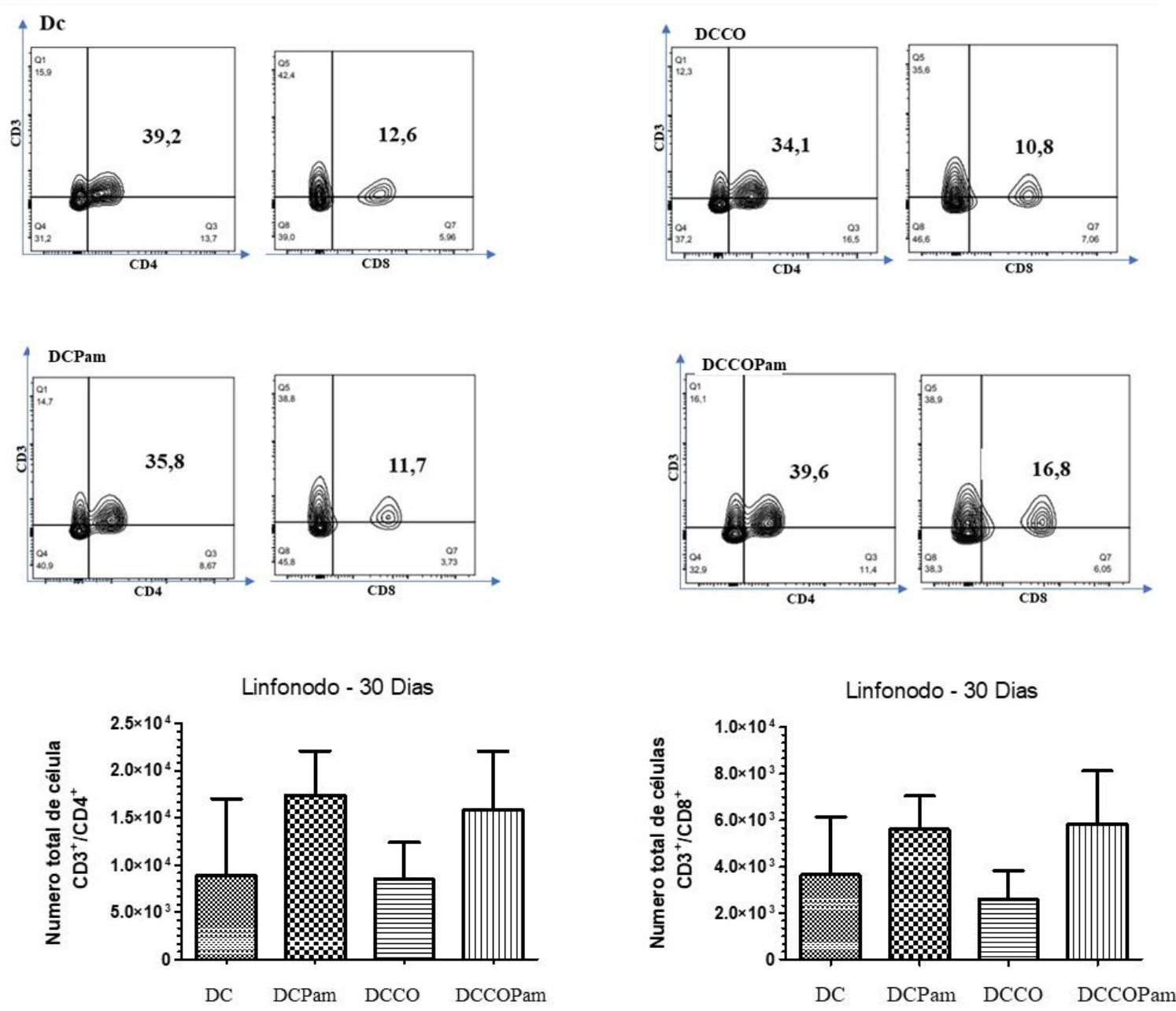

Figura 32. Análise fenotípica de células $\mathrm{CD3}+/ \mathrm{CD} 4+\mathrm{CD3}+/ \mathrm{CD8}+$ do linfonodo obtidas em experimento in vivo. Camundongos BALB/c (4 ou 5 animais por grupo) foram divididos em 4 grupos e posteriormente, submetidos a inoculação, por via intramuscular, da seguinte forma: $1 \times 10^{6}$ de células dendríticas 
(DC), $1 \times 10^{6}$ de células dendríticas com agonista de via TLR2(Pam3CSK4) (DCPam), $1 \times 10^{7}$ de conidios de $F$. pedrosoi com $1 \times 10^{6}$ de células dendríticas (DCCO), $1 \times 10^{6}$ de células dendriticas com $1 \times 10^{7}$ de conídio de $F$. pedrosoi juntamente com agonista de via TLR2 (Pam3CSK4) (DCCOPam).Após 7 dias os camundongos foram submetidos a uma infecção intraperitoneal e eutanasiado ao trigésimo dia. As células foram então marcadas com anti$\mathrm{CD} 3 / \mathrm{CD} 4$ e anti-CD3/CD8. No gráfico de barra, cada barra representa a média $+\mathrm{DP}$. Os dados são representativos do experimento NS.

Em resumo, na infecção de 30 dias apenas o baço demonstrou um aumento de células $\mathrm{TCD}^{+}$no grupo tratado por conídios de F. pedrosoi e agonista de TLR2 (DCCOPam), quando comparados ao tratamento apenas com células dendriticas.

\subsection{Detecção de citocinas por ELISA}

Para investigar o perfil de citocinas do baço, fígado e linfonodo após 15 e 30 dias de infecção, o sobrenadante foi utilizado para a dosagem de IFN- $\gamma$, IL-6, IL-10 e IL-17. Observamos que após 15 e 30 dias de infecção, houve diferença estatística na produção de IFN- $\gamma$ no linfonodo e no baço, respectivamente (Fig 33), assim sendo podemos dizer que o grupo controle (Dc) apresentou uma presença maior dessa citocina quando comparado ao grupo DCPam, ou seja, o grupo previamente sensibilizado com o agonista de TLR2. Quando observamos IL-6, com 15 dias o grupo De mais uma vez apresentou uma presença maior dessa citocina tanto no baço quanto no linfonodo, entretanto quando observamos com 30 dias, somente o fígado demostrou uma diferença notável, no qual o grupo previamente ativado com agonista de TLR2 e com o $F$. pedrosoi, teve uma presença maior de IL-6 quando comparado com o grupo controle (Fig 34). A IL-10 demonstrou que justamente os dois grupos que interagiram previamente com conídios de $F$. pedrosoi, foram os que apresentaram uma quantidade maior dessa citocina com 15 dias nos fígados e linfonodos desses animais tratados e infectados (Fig 35). Ao observarmos IL-17, somente o fígado com 30 dias demonstrou uma presença maior dessa citocina principalmente em camundongos imunizados com conídios de F. pedrosoi e agonistas de TLR2 (Fig 36) 

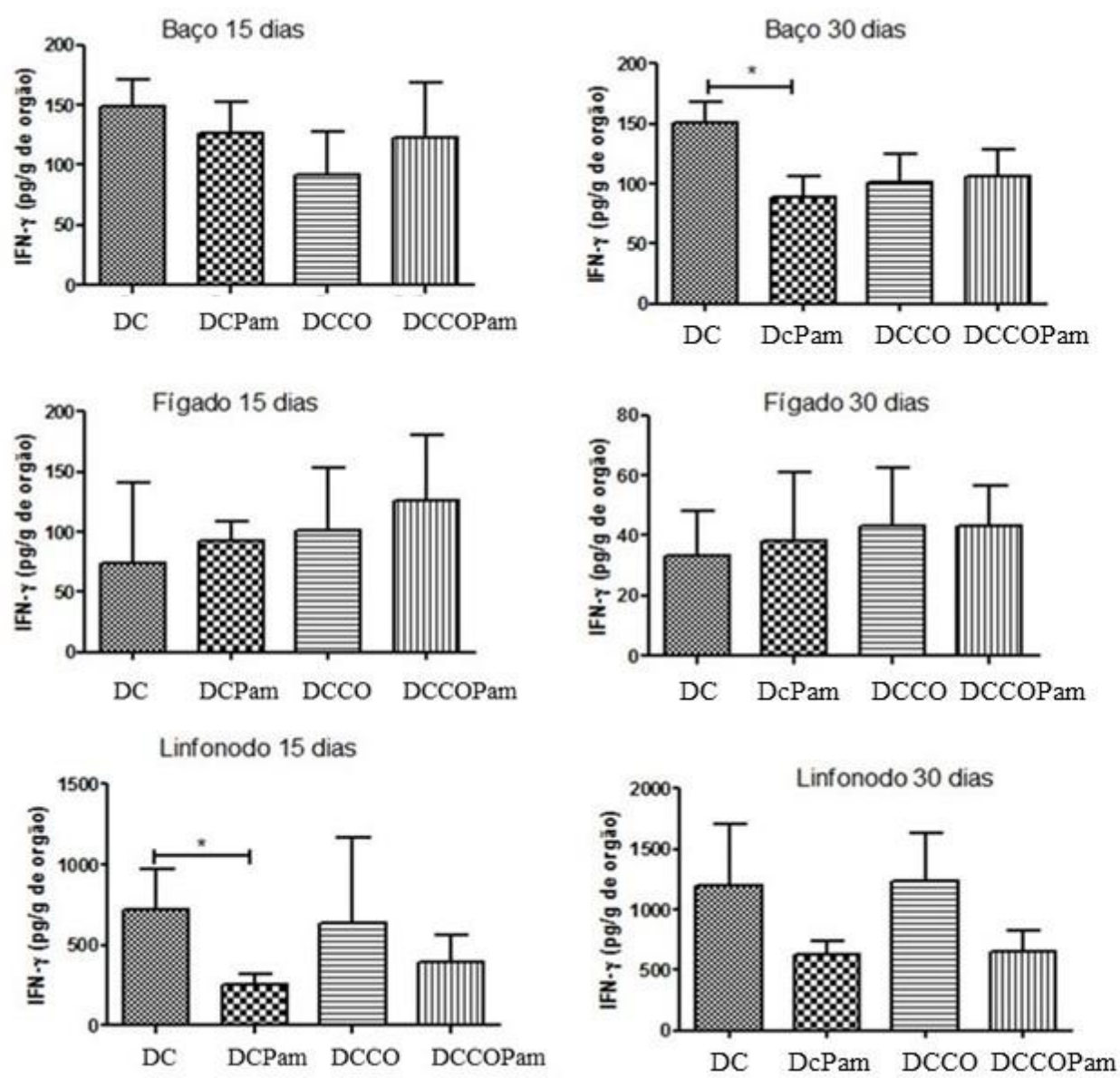

Figura 22. Análise das citocinas: IFN- $\gamma$ obtidas em experimento in vivo. Camundongos BALB/c (4 ou 5 animais por grupo) foram divididos em 4 grupos e posteriormente, submetidos a inoculação, por via intramuscular, da seguinte forma: $1 \times 10^{6}$ de células dendríticas (DC), $1 \times 10^{6}$ de células dendríticas com agonista de via

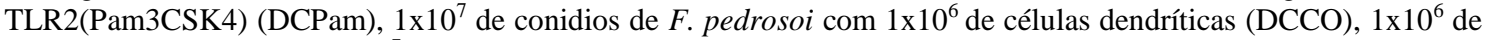
células dendriticas com $1 \times 10^{7}$ de conídio de F. pedrosoi juntamente com agonista de via TLR2 (Pam3CSK4) (DCCOPam).Após 7 dias os camundongos foram submetidos a uma infecção intraperitoneal e eutanasiados. O baço, fígado e linfonodo foram obtidos, macerados e seu sobrenadante coletado para análise de citocinas. No gráfico de barra, cada barra representa a média $+\mathrm{DP} .(* \mathrm{P}<0,05)$. 

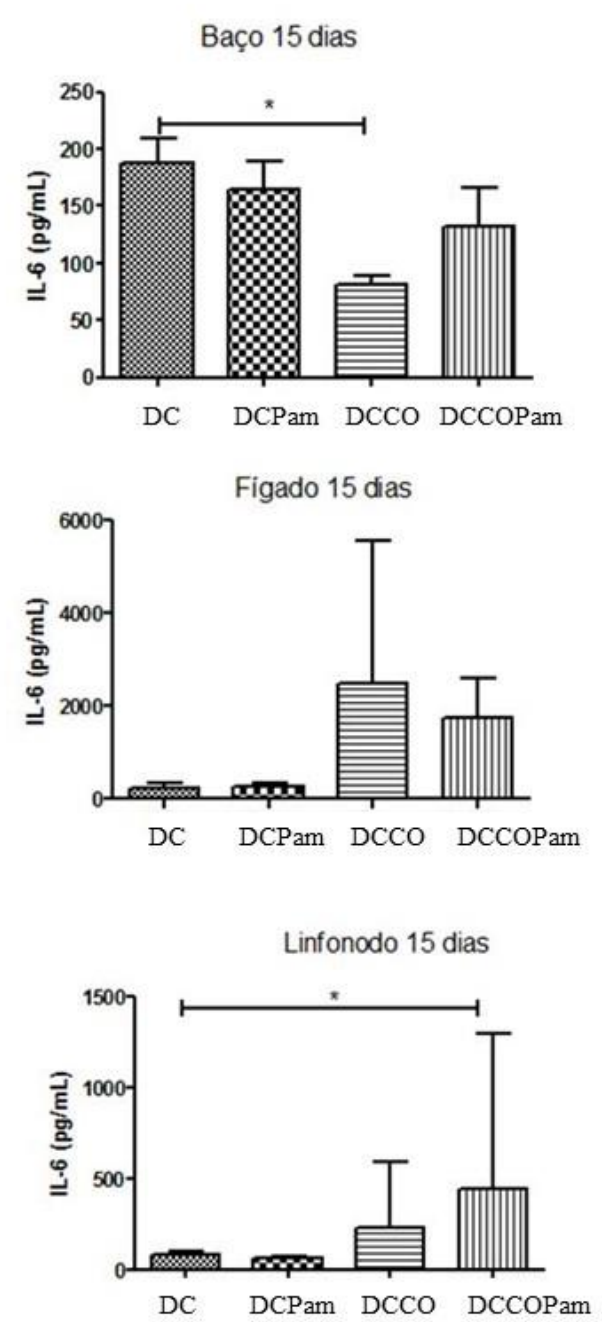

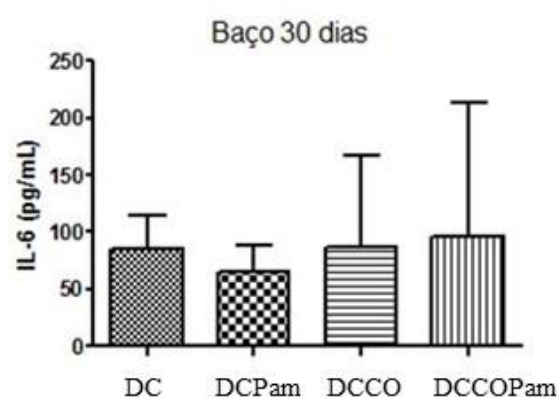

Figado 30 dias
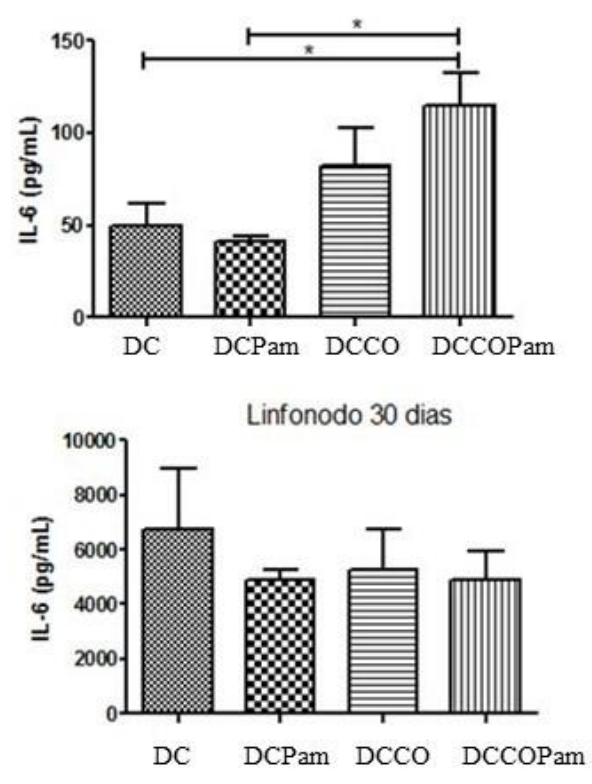

Figura 234. Análise das citocinas: IL-6 obtidas em experimento in vivo. Camundongos BALB/c (4 ou 5 animais por grupo) foram divididos em 4 grupos e posteriormente, submetidos a inoculação, por via intramuscular, da seguinte forma: $1 \times 10^{6}$ de células dendríticas (DC), $1 \times 10^{6}$ de células dendríticas com agonista de via

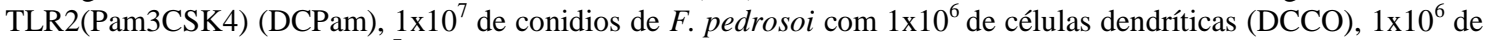
células dendriticas com $1 \times 10^{7}$ de conídio de $F$. pedrosoi juntamente com agonista de via TLR2 (Pam3CSK4) (DCCOPam).Após 7 dias os camundongos foram submetidos a uma infecção intraperitoneal e eutanasiados. O baço, fígado e linfonodo foram obtidos, macerados e seu sobrenadante coletado para análise de citocinas. No gráfico de barra, cada barra representa a média + DP. $(* \mathrm{P}<0,05)$.

Em resumo, houve um aumento na IL-6 do baço de camundongos infectados por 30 dias e previamente tratados com conídios de $F$. pedrosoi e agonista de TLR2 (DCCOPam) quando comparado ao grupo tratado somente com o agonista de TLR2 (DCPam). 

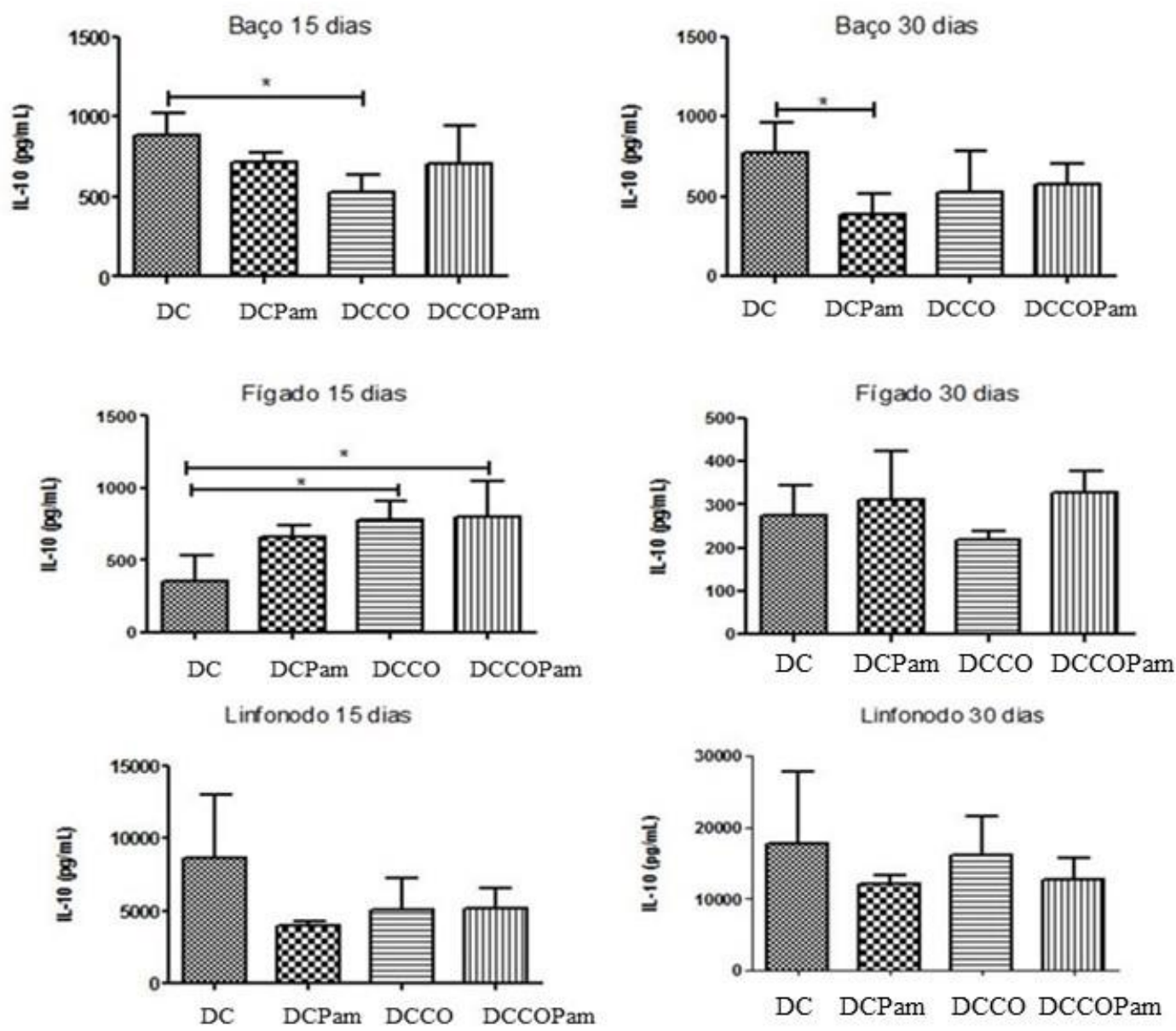

Figura 245. Análise das citocinas: IL-10 obtidas em experimento in vivo. Camundongos BALB/c (4 ou 5 animais por grupo) foram divididos em 4 grupos e posteriormente, submetidos a inoculação, por via intramuscular, da seguinte forma: $1 \times 10^{6}$ de células dendríticas (DC), $1 \times 10^{6}$ de células dendríticas com agonista de via

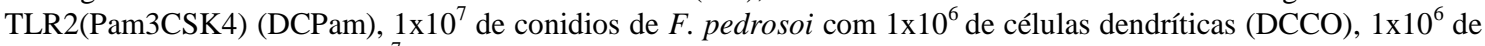
células dendriticas com $1 \times 10^{7}$ de conídio de $F$. pedrosoi juntamente com agonista de via TLR2 (Pam3CSK4) (DCCOPam).Após 7 dias os camundongos foram submetidos a uma infecção intraperitoneal e eutanasiados. O baço, fígado e linfonodo foram obtidos, macerados e seu sobrenadante coletado para análise de citocinas. No gráfico de barra, cada barra representa a média + DP. $(* P<0,05)$. 
Figado 15 dias
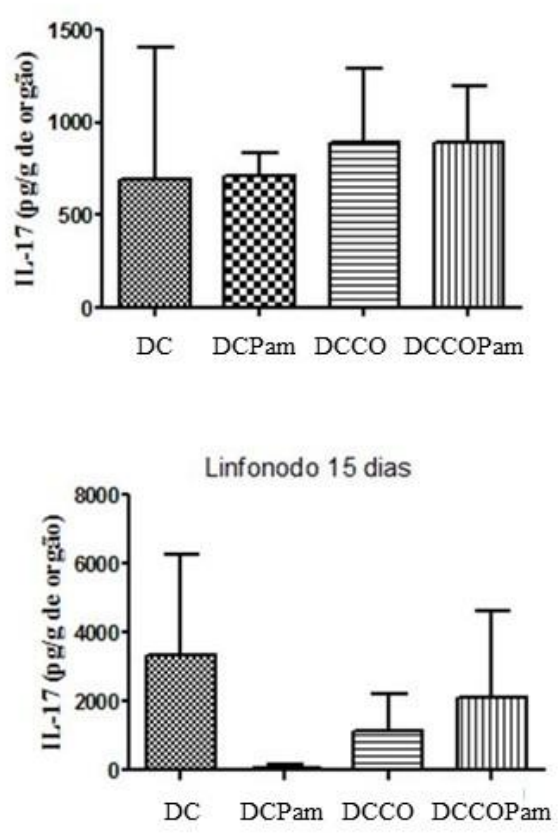

Figado 30 dias
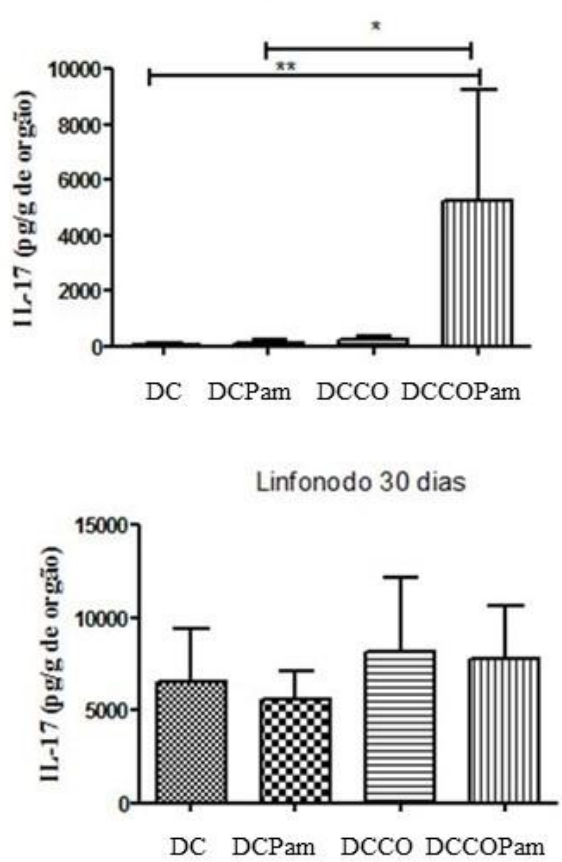

Figura 256. Análise das citocinas: IL-17 obtidas em experimento in vivo. Camundongos BALB/c (4 ou 5 animais por grupo) foram divididos em 4 grupos e posteriormente, submetidos a inoculação, por via intramuscular, da seguinte forma: $1 \times 10^{6}$ de células dendríticas (DC), $1 \times 10^{6}$ de células dendríticas com agonista de via TLR2(Pam3CSK4) (DCPam), $1 \times 10^{7}$ de conidios de F. pedrosoi com $1 \times 10^{6}$ de células dendríticas (DCCO), $1 \times 10^{6}$ de células dendriticas com $1 \times 10^{7}$ de conídio de $F$. pedrosoi juntamente com agonista de via TLR2 (Pam3CSK4) (DCCOPam).Após 7 dias os camundongos foram submetidos a uma infecção intraperitoneal e eutanasiados. O baço, fígado e linfonodo foram obtidos, macerados e seu sobrenadante coletado para análise de citocinas. No gráfico de barra, cada barra representa a média + DP. $(* \mathrm{P}<0,05)$.

Em resumo, a IL-17 demonstrou um aumento no fígado de camundongos infectados por 30 dias e previamente tratados com conídios de F. pedrosoi e agonista de TLR2.

\section{Discussão}

A resistência do hospedeiro a uma infecção fúngica está correlacionada a uma imunidade celular eficaz. Uma resposta imune conduzida por um perfil Th1 vem sendo descrita como a mais eficiente para a eliminação de fungos como Cryptococcus neoformans (WOZNIAK, et al., 2009), Paracoccidioides brasilienses (ROMANO CC, et al., 2005), Aspergillus fumigatus (STEVENS DA, 2006), Fonsecaea pedrosoi (SANTOS ALS, PALMEIRA VF, ROZENTAL S, et al. 2007), entre outros. 
A resposta imune celular eficaz se inicia por meio da ativação de células do sistema imune inato, como as células dendríticas, sendo as primeiras que chegam ao sítio de infecção e possuem não somente a capacidade de fagocitar como também são responsáveis pela ponte entre resposta imune inata e resposta imune adaptativa (BANCHEREAU J, et al., 2000).

Pensando nisso, o presente estudo teve como alvo o uso de células dendríticas para o tratamento prévio de camundongos que foram posteriormente infectados. Nossos primeiros grupos de tratamento tiveram a interação não somente de conídios vivos de $F$. pedrosoi, como também de conídios mortos por calor. Observamos tanto no experimento de 7 dias, quanto no experimento de 30 dias, que não havia diferenças estatísticas que nos motivassem a continuar com o uso dos grupos que tinham o HK (heat killed). As diferenças observadas eram principalmente na interação de agonistas de via TLR, como o Pam3CSK4 e CpG-ODN.

As células dendríticas residem em tecido periférico, como a pele (células de Langerhans), capturando antígenos e migrando para órgãos linfoides fazendo a sensibilização de LT naives. Para que isso ocorra, os antígenos fagocitados são apresentados por moléculas de MHC, assim sendo por meio de citometria de fluxo analisamos a presença dessas moléculas na superfície das células. Podemos observar com 7 dias que o grupo no qual o tratamento possuía células dendríticas ativadas com agonista de TLR2 demonstraram uma presença maior dessas moléculas de MHC-II, principalmente quando comparada aos grupos sensibilizados com HK, com 30 dias somente os grupos controles demonstraram um aumento na expressão de tais moléculas.

Sabe-se que as células dendríticas possuem também a capacidade de proliferar linfócitos Treg dependendo de sinais como ativação de TLR's e citocinas presentes no meio (SALLUSTO F, LANZAVECCHIA A., 1999). Como visto em outros estudos do grupo, os agonistas de via TLR podem ser usados na tentativa de direcionar uma resposta imunológica favorável ao hospedeiro, ou seja, uma resposta de perfil Th1, como visto recentemente por Breda e colaboradores (2020), os quais demonstraram que TLR2 foi essencial para a morte de conídios de $F$. pedrosoi. Corroborando com esses dados apresentados pelo grupo, utilizamos agonistas de TLR2 (Pam3CSK4) e TLR9 (CpG-ODN) e observamos que os grupos previamente tratados com ativação de Dc e agonista de TLR2 (DCPam) com 7 dias de infecção mostraram um perfil fenotípico de célula B maior quando comparado ao grupo de interação prévia de TLR2 e HK (DCHKPam). 
Os mesmos grupos foram avaliados também com 30 dias e observamos que a ativação prévia de TLR2 e a presença de conídios vivos de $F$. pedrosoi, foram capazes de induzir um perfil de $\mathrm{TCD}^{+}{ }^{+}$e $\mathrm{TCD}^{+}$maior quando comparados aos grupos que possuem $\mathrm{HK}$ e/ou $\mathrm{CpG}$, demonstrando assim uma maior eficácia nos grupos que possuem agonistas de TLR2.

Por meio desses experimentos, observamos que o Heat Killed e o agonista de via TLR9 não demonstraram um papel tão promissor no nosso modelo experimental, no qual esperávamos ao iniciarmos o trabalho, assim sendo resolvemos focar apenas nos experimentos in vivo com o fungo vivo e agonista de TLR2.

As doenças fúngicas mostram um paradigma importante na imunologia, tanto podem resultar em uma falta de reconhecimento do patógeno pelo sistema imune ou acarretar uma exacerbada resposta inflamatória no combate ao mesmo. Estudos recentes sobre a virulência dos microrganismos tentam compreender quais os mecanismos que mantêm a homeostasia do sistema imune com o patógeno e ao mesmo tempo, correlacionar com prováveis causas responsáveis pelo colapso desse equilíbrio acarretando um processo infeccioso no qual há a instalação da doença (Romani, 2011).

O TLR nas células T pode funcionar como uma molécula coestimuladora para a ativação das células TCD4 e TCD8 (Marsland BJ, Kopf M., 2007). Um estudo feito por Sun-Mi Lee e colaboradores (2009), confirma que o ligante de TLR2 (Pam3CSK4) fornece um efeito coestimulador potente direto na proliferação de células T mediada por TCR. Entretanto, observaram que a estimulação de TLR2 foi tendenciosa para células T CD8 em vez de células T CD4, não muito diferente do que observamos por citometria de fluxo, vimos que as células dendríticas previamente sensibilizadas com Pam3CSK4 demonstraram um perfil fenotípico mais tendencioso para TCD8, quando comparado com o grupo controle (Dc), já para TCD4 somente com 15 dias o grupo DCPam, mostrou uma presença maior dessas células nos linfonodos.

Os dados corroboram com o estudo realizado por Souza et al., (2011), no qual demonstraram que a fase crônica da cromoblastomicose é decorrente do reconhecimento pela resposta imune inata de forma inadequada, e subsequente falha em induzir uma resposta adaptativa eficiente. A internalização do fungo por si só, não confere proteção ao hospedeiro, é necessário que os fagócitos sejam ativados corretamente para uma boa apresentação e consequentemente, uma resposta imune protetora.

Os TLR são receptores que reconhecem moléculas de padrão específicos encontradas nos patógenos e são responsáveis por direcionar o sistema imune inato a 
induzir uma resposta imune adaptativa mais eficiente frente ao patógeno (Kondo et al., 2012), nessa busca observamos que o grupo controle (Dc) teve uma presença menor de células do perfil TCD4 quando comparado aos grupos que possuem a prévia sensibilização com o agonista de TLR2, podemos considerar o fato do estabelecimento de uma resposta imune adaptativa mais robusta e equilibrada aos 30 dias de infecção e a importância do pré- estímulo com Pam3CSK4.

A imunidade adaptativa contra a cromoblastomicose tem a participação da resposta imune humoral e celular, paciente infectados demonstram uma produção de anticorpos específicos como IgG1, IgM e IgA contra fungos (Esterre et al., 2000; Vidal et al., 2004), porém em doenças fúngicas uma resposta humoral não desempenha um papel tão protetor quanto comparado a uma resposta celular mediada por células do tipo T no perfil Th1 (Queiroz-Telles et al., 2009), assim sendo observamos que os grupos com a participação do agonista de TLR2 induziram uma quantidade maior de células B.

Durante a indução de uma resposta imune celular ou humoral, as células dendríticas, os macrófagos e os linfócitos B respectivamente, desempenham um importante papel como células apresentadoras de antígeno. Na presença de IL-10 a expressão de MHC de classe II diminui nas superfícies das células dendríticas, mas aumenta na superfície dos linfócitos B. Os linfócitos B podem fazer a apresentação antigênica aos linfócitos T de alguns peptídeos (Nisini et al, 2001).

Já sabemos que pacientes com a forma grave da doença possuem uma alta produção de IL-10 e baixa produção de IFN- $\gamma$ (Sousa et al., 2009). Em 15 dias, o linfonodo mostrou maior presença de IFN- $\gamma$ quando comparado ao grupo previamente sensibilizado com agonista de TLR2, baço e fígado não apresentaram uma diferença significativa na produção de IFN- $\gamma$, já em 30 dias de infecção o grupo imunizado somente com célula dendritica (Dc) demostrou um aumento quando comparado ao grupo DCPam.

Com 30 dias, a IL-6 pode ser observada principalmente no fígado de camundongos tratados previamente com agonista de via TLR2 e conídios de $F$. pedrosoi (DCCOPam).

A IL-10 tem como principal fator a inibição da síntese de outras citocinas, como o IFN- $\gamma$, IL-2, IL-12, TNF- $\beta$. Pode também inibir a proliferação de células Th1, fazendo o oposto com células $\mathrm{T}$ de perfil Th2, diminuindo a função citolítica e secretora de citocinas por Th1 e facilitando o desenvolvimento de respostas Th2, ou seja, uma citocina não favorável para uma resposta imune eficiente contra o $F$. pedrosoi. 
A IL-10 demonstrou um aumento no baço do grupo controle (Dc) tanto com 15 dias quanto com 30 dias de infecção, porém com 30 dias podemos observar que a produção dessa citocina no grupo controle está significativamente diminuída quando comparada ao grupo DCPam.

Já no fígado os grupos que mais apresentam essa citocina são os grupos previamente tratados com os conídios vivos de $F$. pedrosoi, corroborando com outros resultados obtidos acima demonstrando a capacidade de escape do fungo.

Os linfócitos Th17 produzem, IL-21, IL-22, IL-26 e as citocinas da família IL17 que são indutoras da inflamação, induzindo uma infiltração celular e produção de outras citocinas inflamatórias (Chen et al., 2007; Mesquita Jr et al., 2010). Em infecções causadas pelo fungo do gênero Coccidioides, observaram que a produção de IL-17 no estágio inicial da doença estimulou o recrutamento de neutrófilos para os pulmões e reparação tecidual (Lin et al., 2010). Recentes relatos sugerem que a produção de citocinas padrão Th17 estão envolvidas no controle de infecções causadas por fungos como Candida spp. e Aspergillus spp., particularmente em condições de deficiência de resposta Th1 (Romani, 2011).

A IL-17 recebe uma atenção considerável desde a sua descoberta em 1993 (Rouvier E. et al., 1993). Sua secreção é promovida pela IL-23 produzida por células $\mathrm{TCD}^{+}$de memória (Manel M., et al 2006).

Ao dosarmos a citocina IL-17, observamos a presença da mesma somente no fígado de camundongos infectados por 30 dias no grupo previamente tratado com conídios vivos e agonista de TLR2 (DCCOPam), demonstrando uma possível exacerbação dessa resposta.

Estudos in situ em lesões de pacientes com CBM, mostram um aumento significativamente maior de IL-17 nos pacientes, quando comparados com outras micoses como a paracoccidioidomicose (Silva AADL., et al., 2014). Não só isso, as lesões da cromoblastomicose também são caracterizadas pela resposta monocítica e neutrofílica intensa, além da presença de citocinas pro-inflamatórias como IL-1 $\beta$, TNFa, IL-6 e IL-17 (Hayakawa M et al., 2006, Ameen M, 2009). Embora a resposta inflamatória seja um importante componente na imunidade contra fungos, a sua desregulação pode ser ainda pior nas infecções fúngicas. Outros estudos apontam que a via de resposta mediada por IL-23 e IL-17 atuam como regulador negativo da resistência aos fungos mediada por Th1, promovendo resposta inflamatória exacerbada atribuída às células do perfil Th1. Tanto a inflamação quanto a infecção são exacerbadas 
na presença de uma expansão desregulada de Th17 em resposta aos fungos (Siqueira I. M., et al 2006).

Por fim, novos estudos se fazem necessários para entender o verdadeiro papel do TLR2 e TLR9 frente à CBM, o presente estudo contribuiu sobremaneira para demonstrar por dados prévios como o tratamento com agonistas de vias TLR2 e TLR9 participam no desenvolvimento de uma resposta imunológica efetiva no desenvolvimento da CBM.

\section{Considerações Finais e Conclusão}

Embora a cromoblastomicose $(\mathrm{CBM})$ não seja reconhecida por seu grau de letalidade, essa compreende uma importante micose subcutânea crônica, cujas complicações podem levar a destruição de órgãos linfáticos, hiperplasias e a eventual amputação de membros acometidos com a doença, causando morbidade entre os pacientes acometidos com a doença (Ameen M., 2009).

Em suma, após análise dos dados podemos concluir que:

- O agonista de via TLR2 (Pam3CSK4) demonstrou, nos camundongos tratados que no curso da infecção, um aumento significativo de células B e células $\mathrm{T}$ de perfil fenotípico $\mathrm{CD} 4^{+}$e $\mathrm{CD} 8^{+}$,

- O grupo DCCOPam demonstrou uma presença maior de células do tipo $\mathrm{TCD}^{+}$, principalmente quando comparado ao grupo tratado com conídios e CpG (DCCOCpG).

- A IL-17 pode ser observada no grupo tratado com conídios de $F$. pedrosoi e agonista de TLR2 (DCCOPam);

- Houve um aumento na IL-6 e IL-10 em camundongos previamente tratados com conídios de F. pedrosoi e agonista de TLR2 (DCCOPam);

- O uso do agonista de TLR2 demonstrou um aumento na carga fúngica de camundongos infectados após 7 dias de tratamento. 


\section{Bibliografia}

ALMEIDA, JOSÉ ROBERTO FOGAÇA; JANNUZZI, GRASIELLE PEREIRA; KAIHAMI, GILBERTO HIDEO; BREDA, LEANDRO CARVALHO DANTAS; FERREIRA, KAREN SPADARI; ALMEIDA, SANDRO ROGÉRIO DE. An immunoproteomic approach revealing peptides from Sporothrix brasiliensis that induce a cellular immune response in subcutaneous sporotrichosis. Scientific Report

ARANGO, M.; JARAMILO, C.; CORTÉS, A.; RESTREPO, A. Auricular chromoblastomycosis by Rhinocladiella aquaspersa. Med. Mycol., Plymouth. 36:43-45, 1998.

BANCHEREAU J, STEINMAN RM. Dendritic cells and the control of immunity. Nature.1998 Mar 19;392(6673):245-52.

BANCHEREAU J, BRIERE F, CAUX C, DAVOUST J, LEBECQUE S, LIU Y et al. Immunobiology of dendritic cells. Annu Rev Immunol 2000; 18:767-811

BREDA, Leandro Carvalho Dantas et al. Fonsecaea pedrosoi conidia and hyphae activate neutrophils distinctly: Requirement of TLR-2 and TLR-4 in neutrophil effector functions. Frontiers in Immunology, [S. l.], p. 36, 6 jan. 2020.

BITTENCOURT, A.L.; LONDERO, A.T.; ANDRADE, J.F. Chromoblastomycosis auricular. Relato de um caso. Rev. Inst. Med. Trop. São Paulo. 36:381-383, 1994.

BONIFAZ A, MARTÍNEZ-SOTO E, CARRASCO-GERARD E, PENICHE J.

Treatment of chromoblastomycosis with itraconazole, cryosurgery, and a combination of both. Int J Dermatol. 1997 Jul; 36(7):542-7

BOURGEOIS C., KUCHLER K., Fungal pathogens-a sweet and sour treat for TLRlike receptors. Front Cell Infect Microbiology, 2012; 2: 142.

CAO Q, JIN Y, JIN M, HE S, GU Q, HE S, QIU Y, GE H, YONEYAMA H, ZHANG Y. Therapeutic effect of MIP-1alpha-recruited dendritic cells on preestablished solid and metastatic tumors. Cancer Lett; 295:17-26, 2010.

CAPLAN , R.M. Sqamous carcinoma in a longstanding lesion of chromoblastomycosis. Arch Dermatol, 97:38, 1968

CAPILLA J, CLEMONS KV, STEVENS DA. The friend of man again? Saccharomyees(s) as a vaccine against invasive aspergillosis. 47th Intersci. Conf. Antimicrib. Agents Chemother. 2007 (Sept), Chicago, Abst. G-1708.

CARDONA, C. N; AGUDELO, F. P, Development of a chronic chromoblastomycosis model in immunocompetent mice, Med Mycol. 1999 Apr; 37(2):81-3.

CASTRO LG, PIMENTEL ER, LACAZ CS. Treatment of chromomycosis by cryosurgery with liquid nitrogen: 15 years' experience. Int J Dermatol. 2003 May; 42(5):408-12. 
CASTRO, L. G. M. Chromomycosis: a therapeutic challenge (letter). Clin Infect Dis, Chicago, v. 15, p. 553-554, 1992.

CASTRO, L. G. M. Tratamento da cromoblastomicose pela criocirurgia com nitrogênio líquido. Tese de doutorado. Faculdade de Medicina da Universidade de São Paulo. São Paulo, 1998

CHEN Z, TATO CM, MUUL L, LAURENCE A, O'SHEA JJ. Distinct regulation of interleukin-17 in human T helper lymphocytes. Arthritis Rheum. 2007; 56(9): 2936-46.

CRIADO PR, OLIVEIRA CB, DANTAS KC, TAKIGUTI FA, BENINI LV, VASCONCELLOS C. Superficial mycosis and the immune response elements. An Bras Dermatol. 2011 Jul-Aug; 86(4):726-31

DE HOOG GS, NISHIKAKU AS, FERNANDEZ-ZEPPENFELDT G, PADÍNGONZÁLEZ C, BURGER E, BADALI H, RICHARD-YEGRESES N, VAN DEN ENDE AH. Molecular analysis and pathogenicity of the Cladophialophora carrionii complex, with the description of a novel species. Stud Mycol; 58: 219-234, 2007.

DE HOOG, G. Significance of fungal evolution for the understanding of their pathogenicity, illustrated with agents of phaeohyphomycosis. Mycoses.40 Suppl. 2:5- 8. 1997.

ELGART GW. Chromoblastomycosis. Dermatol Clin. 1996 Jan;14 (1):77-83.

FANGER, N. A.; WARDWELL, K.; SHEN, L.; TEDDER, T. F.; GUYRE, P. M. Type I (CD64) and type II (CD32) Fc gamma receptor-mediated phagocytosis by human blood dendritic cells. Journal of Immunology , v. 157, p.541-548, 1996.

GELMAN AE, ZHANG J, CHOI Y, TURKA LA. TLR-like receptor ligands directly promote activated CD4+T cell survival. J Immunol.2004 May 15;172(10):6065-73

GIMENES, V. M. F.; SOUZA, M. G.; FERREIRA, K. S.; MARQUES, S. G.; GONÇALVES, A. G.; SANTOS, D. V. C. L.; PEDROSO e SILVA, C. M.; ALMEIDA, S.R. Cytokines and lymphocyte proliferation in patients wich different clinical forms of chromoblastomycosis. Microbes and Infection,7(4), 708-713, Apr, 2005.

GUERMONPREZ, P.; VALlADEAU, J.; ZITCOGEL， L.; THÉRY, C.; 6 AMIGORENAS, S. Antigen presentation and $\mathrm{T}$ cell stimulation by dendritic cells. Annu. Rev. Immunol. 20:621-67, 2002.

GHOSH, MAY MJ, KOOP EB. NF-Kappa B and Rel Proteins : Evolutionarily conserved mediators of immune responses. Annu Rev. Immunol.1998; 16:225-60

GIMMI CD, FREEMAN GJ, GRIBBEN JG, GRAY G, NADLER LM. Human T-cell clonal anergy is induced by antigen presentation in the absence of B7 costimulation. Proc Natl Acad Sci U.S.A. 1993 Jul 15;90(14):6586-90

HAYAKAWA M., GHOSN E. E. B., TEIXEIRA DE SOUSA M. G., FERREIRA K. S., ALMEIDA S. R., Phagocytosis, production of nitric oxide and pro-inflammatory cytokines by macrophages in the presence of dematiaceous fungi that causes 
chromoblastomycosis. Scandinavian Journal of Immunology, 64(4), 382-387, Oct, 2006.of Immunology, 64(4), 382-387, Oct, 2006.

HIRA K, YAMADA H, TAKAHASHI Y, OGAWA H. Successful treatment of chromomycosis using carbon dioxide laser associated with topical heat applications. $\mathrm{J}$ Eur Acad Dermatol Venereol. 2002 May; 16(3):273-5.

HUFFNAGLE, G. B.; DEEP, G.S. Innate and adaptive determinants of host susceptibility to medically important fungi. Curr. Opin. Microbiol, v. 6, p. 344- 350, 2003.

HUANG AY, QI H, GERMAIN RN. Illuminating the landcape of in vivo immunity: insights from dynamic in situ imaging of secondary lymphoid tissues. Immunity. 2004 Sep; 21(3):331-9

INABA K, INABA M, ROMANI N, AYA H, DEGUCHI M, IKEHARA S, MURAMATSU S, STEINMAN RM. Generation of Large Numbers of Dendritic Cells from Mouse Bone Marrow Cultures Supplemented with Granulocyte/Macrophage Colony-stimulating Factor, J Exp Med. 1992 Dec 1;176(6):1693-702.

IWASAKI A, MEDZHITOV R. TLR -like receptor control of the adaptative immune responses. Nat Immunol.2004 Oct; 5(10):987-95

JANKOVIC, D.; LIU, Z.; GAUSE, W. C. Th-1 and Th2-cell commitment during infectious disease: asymmetry in divergent pathways. Trends in Immunology. v.22, n.8, p.450-457, 2001.

JANNUZZI, GRASIELLE PEREIRA; SOUZA, NICOLE DE ARAÚJO ; FRANÇOSO, KÁTIA SANCHES ; PEREIRA, RONEY HENRIQUE ; SANTOS, RAQUEL POSSEMOZER ; KAIHAMI, GILBERTO HIDEO ; ALMEIDA, JOSÉ ROBERTO FOGAÇA DE ; BATISTA, WAGNER LUIZ ; AMARAL, ANDRÉ CORRÊA ; MARANHÃO, ANDREA QUEIROZ ; ALMEIDA, SANDRO ROGÉRIO DE ; FERREIRA, KAREN SPADARI . Therapeutic treatment with scFv-PGLA nanoparticles decreases pulmonary fungal load in a murine model of Paracoccidioidomycosis. MICROBES AND INFECTION, 2017.

KAPLAN W, CHANDLER FW, AJELLO L, GAUTHER R, HIGGINS R, CAYOUETTE P Equine phaeohyphomycosis caused by Drechslera spicifera. Can Vet J. 1975 Jul;16(7):205-8.

KIMURA, T. F. E. Análise da capacidade migratória de células dendríticas na cromoblastomicose experimental. 2012. 82 f. Dissertação Mestrado em Análises Clínicas - Faculdade de Ciências Farmacêuticas, Universidade de São Paulo, São Paulo, 2012.

KONDO T, KAWAI T, AKIRA S. Dissecting negative regulation of Toll-like receptor signaling. TRENDS IMMUNOL. 2012; 33(9): 449-58.

LACAZ, C. S. Imunidade humoral e celular nas micoses. In: Lacaz C. da S., Porto E. Martins JEC, Heins-Vaccari EM, Melo NT. Tratado de Micologia Médica. São Paulo: Savier, 2002: 830-863. 
LEMAITRE B, NICOLAS E, MICHAUT L, REICHHART JM, HOFFMAN JA. The dorsoventral regulatory gene cassette spätzle/ TLR/Cactus controls the potent antifungal response in Drodophila adults. Cell. 1996 Sep 20;86(6):973-83.

LIN Y, SLIGHT SR, KHADER SA. Th17 cytokines and vaccine-induced immunity. Semin Immunopathol. 2010; 32(1): 79-90

LIPSCOMB, M. F.; MASTEN B. J. Dendritic cells: immune regulators in heat and disease. Physiol. Rev. Jan: 82(1):97-130, 2002.

LIU Y, JANEWAY CA Jr. Cell that presents both specific ligand and coestimulatory activity are the most efficient inducers of clonal expansion of normal CD4 T cells. Proc Natl Acad Sci USA. 1992 May 1;89(9):3845-9

LUPI O, TYRING SK, MCGINNIS MR. Tropical dermatology: fungal tropical diseases. J Am Acad Dermatol. 2005 Dec; 53(6):931-51, quiz 952-4.

MAGLIONE PJ, SIMCHONI N, CUNNINGHAM-RUNDLES C., TLR-like receptor signaling in primary immune deficiencies. Annals of the New York Academy of Sciences, 2015.

MARSLAND BJ, KOPF M. Toll-like receptors: paving the path to $\mathrm{T}$ cell-driven autoimmunity Curr Opin Immunol. 2007;19:611-614

MESQUITA JR D, CRUVINEL WM, CÂMARA NO, KÁLLAS EG, ANDRADE LE. Autoimmune diseases in the TH17 era. Braz J Med Biol Res. 2009; 42(6): 476- 86.

MCCORMACK, F. X.; GOBBONS, R.; WARD, S. R.; KUZMENKO, A.; WU, H.; DEEP, G. S. Macrophage-independent fungicidal action of the pulmonary colletins. J. Infect. Dis., v.278, p. 36250-36256, 2003.

Mussalem, Juliana Sekeres ; Squaiella-Baptistão, Carla Cristina ; Teixeira, Daniela ; Yendo, Tatiana Mina ; Thies, Felipe Garutti ; Popi, Ana Flavia ; Mariano, Mario ; LongoMaugéri, Ieda ; Longo-Maugéri,I.M . Adjuvant Effect of Killed Propionibacterium acnes on Mouse Peritoneal B-1 Lymphocytes and Their Early Phagocyte Differentiation. Plos One , v. 7, p. e33955, 2012.

HAYAKAWA M, GHOSN EEB, da GLORIA TEIXEIRA DE SOUSA M, FERREIRA KS, ALMEIDA SR. Phagocytosis, production of nitric oxide and pro-inflammatory cytokines by macrophages in the presence of dematiaceous fungi that cause chromoblastomycosis. Scand J Immunol [Internet]. 2006

ODDS, F.C.; ARAI. T; DISALVO, A. F .; EVANS , E.G.V.; HAY, R.J; RANDHAWA, H.S.; RINALDI, M.G.; WALSH, T.J. Nomenclature of fungal disease: a report and recommendation from a sub-committee of the International Society for Human and Animal Mycology (ISHAM). J. MED. VET. Mycol., Dorchester. V. 30, p 1-10, 1992

POIRRIEZ J, BREUILLARD F, FRANCOIS N, FRUIT J, SENDID B, GROSS S, DEICAS E. A case of chromomycosis treated by a combination of cryotherapy, shaving, oral 5-fluorocytosine, and oral amphotericin B. Am J Trop Med Hyg. 2000 Jul-Aug; 63(1-2):61-3. 
QUEIROZ-TELLES, F.; WANKE, B.W.; MONTEIRO, P.C.F.; BORDIGNON, G.F.;RAMOS, L.R.; LONDERO, A.T. Chromoblastomycosis caused by different species of Exophiala. In: XXXII Congresso da Soc. Bras. Med. Trop., 1996. Rev. Soc. Bras. Med. Trop. 29: 117, 1997.

QUEIROZ-TELLES F, SYBREN de HOOG, DANIEL WGANER C. L. SANTOS, CLAUDIO GUEDES SALGADO, VANIA APARECIDA VICENTE, ALEXANDRO BONIFAZ, EMMANUEL ROILIDES, LIYAN XI, CONCEIÇÃO de MARIA PEDROZO e SILVA AZEVEDO, MOISES BATISTA da SILVA, ZOE DOROTHEA PANA, ARNALDO LOPES COLOMBO, THOMAS J. WALGHL. Clinical Microbiology Revews, 2016.

RIPPOM, J. M.. The pathogenic fungi and the pathogenic actinomyces. 3a ed., Philadelphia, W. B. Saunders Co., Medical Mycology 1988.

ROMANI, L. Immunity to fungal infections. Nature Rev. Immunol., v.4, p. 1-23, 2004.

SALLUSTO F, LANZAVECCHIA A. Mobilizing dendritic cells for tolerance, priming, and chronic inflammation. J Exp Med 1999; 189:611-4.

SAN BLAS, G. The Cell Wall of Fungal human pathogens: It's possible role inhost relationships. Mycopatohologia, 79: 159-184, 1982.

SHORTMAN K, LIU YJ. Mouse and human dendritic cells subtypes. Nat Rev Immunol 2002; 2:151-61. 10. Sallusto F, Lanzavecchia A. Mobilizing dendritic cells for tolerance, priming, and chronic inflammation. J Exp Med 1999; 189:611-4.

ROMANO CC, MENDES-GAIANNINI MJ, DUARTE AJ, BENARD G. The role of interleukin 10 in the differential expression of interleukin-12p70 and its beta2 receptor on patients with active or treated paracoccidioidomycosis and healthy infected subjects. Clin Immunol. 2005; 14:86-94

ROMANI L. Immunity to fungal infections. Nat Rev Immunol. 2004; 4: 1-23

ROMANI L. Immunity to fungal infections. Nat Rev Immunol. 2011; 11(4): 275- 88.

SANTOS ALS, PALMEIRA VF, ROZENTAL S, et al. Biology and pathogenesis of Fonsecaea pedrosoi, the major etiologic agent of chromoblastomycosis. FEMS. 2007;31:570-91.

SILVA AADL, CRIADO PR, NUNES RS, da SILVA WLF, KANASHIRO-GALO L, DUARTE MIS, et al. In Situ Immune Response in Human Chromoblastomycosis - A Possible Role for Regulatory and Th17 T Cells. PLoS Negl Trop Dis [Internet]. 2014;8(9):e3162. Available from: http://dx.plos.org/10.1371/journal.pntd.0003162

SOUSA MDA G, REID DM, SCHWEIGHOFFER E, TYBULEWICZ V, RULAND J, LANGHORNE J, YAMASAKI S, TAYLOR PR, ALMEIDA SR, BROWN GD. Restoration of Pattern Recognition Receptor Costimulation to Treat Chromoblastomycosis, a Chronic Fungal Infection of the Skin, Cell Host Microbe. 19; 9(5):436-43, 2011 
STEINMAN RM, HAWIGER D, NUSSENZWEIG MC.; Tolerogenic dendritic cells. Annu Rev Immunol. 2003;21:685-711

STEVENS DA. Th1/Th2 in aspergillosis. Med Mycol. 2006;1:229-35.

TAGAMI, H.; TORINUKI, W.; OKOHCHI, K.; TAKEMATSU, H .; Activation of the alternative complement pathway by Fonsecaea pedrosoi. The Journal of investigative dermatology . 83: 308-310, 1984.

TASSANEETRITHEP

B, BURGESS

TH, GRANELLI-PIPERNO

A, TRUMPFHELLER C, FINKE J, SUN W, ELLER MA, PATTANAPANYASAT

$\mathrm{K}$, SARASOMBATH S, BIRX DL, STEINMAN RM, SCHLESINGER

S, MAROVICH MA. DC-SIGN (CD209) mediates dengue virus infection of human dendritic cells. J. Exp. Med., v.197, n.7, Apr 7, p.823-9, 2003.

TIBIRIÇÁ, P.Q.T.;Anatomia patológica da deramatide verrucosa cromomicótica. São Paulo. 1939. Tese, Faculdade de Medicina de São Paulo.

TORINUKI, W; OKOHCHI, K, TAKEMATSU, H; TAGAMI H; Activation of alternative complement pathway by Fonsecaea pedrosoi. The Jornal of Investigative dermatology.83: 308-310, 1984.

TORRES E, BERISTAIN JG, LIEVANOS Z, ARENAS R Chromoblastomycosis associated with a lethal squamous cell carcinoma. An Bras Dermatol. 2010;85(2):26770 .

UENO K, URAI M, OHKOUCHI K, MIYAZAKI Y, KINJO Y, Dendritic Cell-Based Vaccine Against Fungal Infection, Methods Mol Biol. 2016;1403:537-49.

UNANUE, E. R.; ALLEN, P. M. The basis for the immunoregulatory role of macrophages and other accessory cells. Science, 236: 551-557, 1987.

URIBE, F; ZULUACA, A.I; LEON, W; RESTREPO, A.Histopatology of Chromobastomicosys. Mycophatology, 105:1-6, 1989.

VYAS, M.C.; JOSHI, Y.R.; BHARGAVA, N.; JOSHI, K.R.; TANWAR, R. K. Cerebral chromoblastomicosis - a rare case report of cerebral abscess and brief review of literature - a case report. Indian J. Pathol. Microbiol, 43: 81-5, 2000.

WOZNIAK, KL, RAVI S, MACIAS S, et al. Insights into the mechanisms of protective immunity against Cryptococcus neoformans infection using a mouse model of pulmonary cruptococcosis. PLoS One. 2009;4(9):e6854. 
UNIVERSIDADE DE SÃO PAULO

FACULDADE DE CIÊNCIAS FARMACÊUTICAS

Comissão de Ética no Uso de Animais - CEUA

CEUAVFCF 128.2018-P575

\section{CERTIFICADO}

Certificamos que a proposta intitulada Avaliaçăo da resposta imune induzida por células dendriticas previamente ativadas por Fonsecaea pedrosoi e agonistas das vias de Toll-2 e Toll-9 na Cromoblastomicose experimental, registrada com $0 n^{\circ} 575$, sob a responsabilidade do(a) pesquisador(a) Larissa Neves Monteiro Paulo, sob orientaçăo do Prof. Dr. Sandro Rogério de Almeida - que envolve produção ou manutençăo ou utilização de animais pertencentes ao filo Chordata, subfilo Vertebrata (exceto humanos), para fins de pesquisa cientifica - encontra-se de acordo com os preceitos da Lei Federal $n^{\circ} 11.794$, de 8 de outubro de 2008 , do Decreto Federal $n^{\circ} 6.899$, de 15 de julho de 2009 , e das normas editadas pelo Conselho Nacional de Controle de Experimentaçăo Animal (CONCEA), e foi aprovada pela Comissão de Ética no Uso de Animais (CEUA) da Faculdade de Ciências Farmace̊uticas da Universidade de São Paulo (FCF/USP), em reuniāo de 14 de dezembro de 2018.

\begin{tabular}{|l|l|}
\hline Finalidade & Pesquisa Cientifica \\
\hline Vigéncia da autorizaçăo & $14 / 12 / 2018$ a $31 / 01 / 2021$ \\
\hline Espécie/linhagem/raça & Camundongo - BALB/C \\
\hline Número de animais & 315 \\
\hline Sexo & Fêmea \\
\hline Peso/ldade & 8 a 12 semanas $-21 \mathrm{~g}$ \\
\hline Origem & Faculdade de Medicina FMUSP \\
\hline
\end{tabular}

Conforme a legislação vigente, deverá ser apresentado, no encerramento do projeto de pesquisa, o respectivo relatório final.

Săo Paulo, 17 de dezembro de 2018.

-1) suftorhe

Profa. Dra. Neuza Mlariko Aymoto Hassimotto Coordenadora CEUA/FCF/USP 


\section{Universidade de São Paulo \\ Faculdade de Ciências Farmacêuticas \\ FICHA DO ALUNO}

\begin{tabular}{|c|c|}
\hline Email: & larissamonteiropaulo@usp.br \\
\hline Data de Nascimento: & $15 / 03 / 1996$ \\
\hline Cédula de Identidade: & $\mathrm{RG}-42.496 .990-7-\mathrm{SP}$ \\
\hline Local de Nascimento: & Estado de São Paulo \\
\hline Nacionalidade: & Brasileira \\
\hline Graduação: & Bacharela em Biomedicina - Universidade Cidade de São Paulo - São Paulo - Brasil - 2018 \\
\hline Curso: & Mestrado \\
\hline Programa: & Farmácia (Fisiopatologia e Toxicologia) \\
\hline Área: & Fisiopatologia \\
\hline Data de Matrícula: & $20 / 08 / 2018$ \\
\hline Início da Contagem de Prazo: & $20 / 08 / 2018$ \\
\hline Data Limite para o Depósito: & $22 / 02 / 2021$ \\
\hline Orientador: & Prof(a). Dr(a). Sandro Rogerio de Almeida - 20/08/2018 até o presente. Email: sandroal@usp.br \\
\hline Proficiência em Linguas: & Inglês, Aprovado em 20/08/2018 \\
\hline $\begin{array}{l}\text { Data de Aprovação no Exame de } \\
\text { Qualificação: }\end{array}$ & Aprovado em 29/08/2019 \\
\hline Data do Depósito do Trabalho: & $16 / 02 / 2021$ \\
\hline Titulo do Trabalho: & $\begin{array}{l}\text { "Avaliação da resposta imune induzida por células dendríticas previamente ativadas com agonistas } \\
\text { das vias TLR-2 e TLR-9 na Cromoblastomicose experimental" }\end{array}$ \\
\hline $\begin{array}{l}\text { Data Máxima para Aprovação da } \\
\text { Banca: }\end{array}$ & $05 / 04 / 2021$ \\
\hline \multicolumn{2}{|l|}{ Data de Aprovação da Banca: } \\
\hline \multicolumn{2}{|l|}{$\begin{array}{l}\text { Data Máxima para Defe } \\
\text { Data da Defesa: } \\
\text { Resultado da Defesa: }\end{array}$} \\
\hline Histórico de Ocorrências: & Primeira Matrícula em 20/08/2018 \\
\hline
\end{tabular}

Histórico de Ocorrências:

Primeira Matrícula em 20/08/2018

Aluno matriculado no Regimento da Pós-Graduação USP (Resolução n 6542 em vigor de 20/04/2013 até 28/03/2018). Última ocorrência: Matrícula de Acompanhamento em 27/07/2020 Impresso em: 22/02/2021 13:30:44

Janus - Sistema Administrativo da Pós-Graduação 


\section{Universidade de São Paulo \\ Faculdade de Ciências Farmacêuticas \\ FICHA DO ALUNO}

9142 - 10533275/1 - Larissa Neves Monteiro Paulo

\begin{tabular}{|c|c|c|c|c|c|c|c|c|c|}
\hline Sigla & Nome da Disciplina & Início & Término & $\begin{array}{c}\text { Carga } \\
\text { Horária }\end{array}$ & Cred. & Freq. & Conc. & Exc. & . Situação \\
\hline $\begin{array}{c}\mathrm{FBC} 5709 \\
7 / 1\end{array}$ & Biologia Molecular em Análises Clínicas & $12 / 09 / 2018$ & $10 / 10 / 2018$ & 60 & 4 & 100 & A & $\mathrm{N}$ & Concluída \\
\hline$\underset{7 / 2}{\mathrm{FBC} 5707-}$ & Biologia de Sistemas para Ciências da Vida & $02 / 10 / 2018$ & $24 / 12 / 2018$ & 60 & 0 & - & - & $\mathrm{N}$ & $\begin{array}{l}\text { Matrícula } \\
\text { cancelada }\end{array}$ \\
\hline $\begin{array}{l}\text { BMI5862- } \\
10 / 3\end{array}$ & $\begin{array}{l}\text { Seminário Didático-Cientifico em Imunologia I (Instifuto de } \\
\text { Ciências Biomédicas - Universidade de São Paulo) }\end{array}$ & $07 / 02 / 2019$ & $22 / 05 / 2019$ & 60 & 0 & - & - & $\mathrm{N}$ & $\begin{array}{l}\text { Matrícula } \\
\text { cancelada }\end{array}$ \\
\hline$\underset{3 / 2}{\text { MIP } 5735-}$ & $\begin{array}{l}\text { Infeccōes Fúngicas em Imunodeprimidos (Faculdade de } \\
\text { Medicina - Universidade de São Paulo) }\end{array}$ & $01 / 03 / 2019$ & $04 / 04 / 2019$ & 90 & 0 & - & - & $\mathrm{N}$ & $\begin{array}{l}\text { Matrícula } \\
\text { cancelada }\end{array}$ \\
\hline$\underset{7 / 5}{\operatorname{MCM} 5772-}$ & $\begin{array}{l}\text { Temas Básicos de Imunologia (Faculdade de Medicina - } \\
\text { Universidade de São Paulo) }\end{array}$ & $06 / 03 / 2019$ & $02 / 04 / 2019$ & 60 & 4 & 90 & B & $\mathrm{N}$ & Concluida \\
\hline $\begin{array}{l}\text { BMI5881- } \\
6 / 2\end{array}$ & $\begin{array}{l}\text { Regulação da Resposta Imune (Instituto de Ciências } \\
\text { Biomédicas - Universidade de São Paulo) }\end{array}$ & $11 / 03 / 2019$ & $05 / 05 / 2019$ & 120 & 0 & - & - & $\mathrm{N}$ & $\begin{array}{l}\text { Matrícula } \\
\text { cancelada }\end{array}$ \\
\hline $\begin{array}{l}\text { ICB5709- } \\
7 / 1\end{array}$ & $\begin{array}{l}\text { Ensaios Pedagógicos (Instituto de Ciências Biomédicas - } \\
\text { Universidade de São Paulo) }\end{array}$ & $12 / 03 / 2019$ & $15 / 04 / 2019$ & 45 & 3 & 90 & A & $\mathrm{N}$ & Concluida \\
\hline $\begin{array}{c}\text { FBC5793 } \\
14 / 2\end{array}$ & Tópicos em Fisiopatologia e Toxicologia I & $12 / 03 / 2019$ & $24 / 06 / 2019$ & 15 & 1 & 88 & A & $\mathrm{N}$ & Concluida \\
\hline $\begin{array}{c}\text { FBA5728- } \\
4 / 8\end{array}$ & Aprimoramento Pedagógico & $02 / 04 / 2019$ & $30 / 04 / 2019$ & 60 & 0 & - & - & $\mathrm{N}$ & $\begin{array}{l}\text { Pré- } \\
\text { matrícula } \\
\text { indeferida }\end{array}$ \\
\hline$\underset{8 / 3}{\mathrm{FBC} 5757-}$ & Tópicos em Fisiopatologia e Toxicologia II & $06 / 08 / 2019$ & $18 / 11 / 2019$ & 15 & 1 & 87 & B & $\mathrm{N}$ & Concluida \\
\hline $\begin{array}{c}\text { BMI5904- } \\
1 / 1\end{array}$ & $\begin{array}{l}\text { Reconhecimento Molecular pelo Sistema Imune (Instituto de } \\
\text { Ciências Biomédicas - Universidade de São Paulo) }\end{array}$ & $12 / 08 / 2019$ & $15 / 09 / 2019$ & 60 & 0 & - & - & $\mathrm{N}$ & $\begin{array}{l}\text { Matricula } \\
\text { cancelada }\end{array}$ \\
\hline $\begin{array}{c}\text { BMI5905- } \\
1 / 1\end{array}$ & $\begin{array}{l}\text { Mecanismos Efetores da Resposta Imune (Instituto de } \\
\text { Ciências Biomédicas - Universidade de São Paulo) }\end{array}$ & $13 / 08 / 2019$ & $16 / 09 / 2019$ & 60 & 0 & - & - & $\mathrm{N}$ & $\begin{array}{l}\text { Matrícula } \\
\text { cancelada }\end{array}$ \\
\hline$\underset{4 / 3}{\mathrm{FBC} 5727-}$ & $\begin{array}{l}\text { Tópicos Avançados da Imunidade Inata Induzida por Fungos } \\
\text { Patogênicos }\end{array}$ & $04 / 11 / 2019$ & $09 / 12 / 2019$ & 60 & 4 & 100 & A & $\mathrm{N}$ & Concluida \\
\hline${ }_{1 / 1}^{\text {QBQ5592- }}$ & $\begin{array}{l}\text { Comunicação e Divulgação Científicas: Passando sua } \\
\text { Mensagem de Forma Eficaz (Instituto de Química - } \\
\text { Universidade de São Paulo) }\end{array}$ & $02 / 03 / 2020$ & $08 / 03 / 2020$ & 30 & 2 & 100 & A & $\mathrm{N}$ & Concluída \\
\hline$\underset{1 / 1}{\text { FBC } 5959}$ & $\begin{array}{l}\text { Desenvolvendo sua comunicação científica no mundo } \\
\text { acadêmico }\end{array}$ & $19 / 03 / 2020$ & $29 / 04 / 2020$ & 90 & 6 & 100 & A & $\mathrm{N}$ & Concluida \\
\hline $\begin{array}{c}\text { ICB5744 } \\
2 / 2\end{array}$ & $\begin{array}{l}\text { Fisiopatologia do Inflamassoma: The Good, The Bad and The } \\
\text { Ugly (Instituto de Ciências Biomédicas - Universidade de São } \\
\text { Paulo) }\end{array}$ & $11 / 05 / 2020$ & $24 / 05 / 2020$ & 60 & 0 & - & - & $\mathrm{N}$ & $\begin{array}{l}\text { Matrícula } \\
\text { cancelada }\end{array}$ \\
\hline$\underset{5 / 3}{\mathrm{FBC} 5722}$ & Controle Hormonal da Resposta Inflamatória & $11 / 05 / 2020$ & $31 / 05 / 2020$ & 60 & 0 & - & - & $\mathrm{N}$ & $\begin{array}{l}\text { Matrícula } \\
\text { cancelada }\end{array}$ \\
\hline
\end{tabular}

\begin{tabular}{|l|ccc|}
\hline & \multicolumn{2}{|c|}{ Créditos mínimos exigidos } & Créditos obtidos \\
\hline & Para exame de qualificação Para depósito da dissertaçäo & \\
\hline Disciplinas: & 0 & 25 & 25 \\
\hline Estágios: & 0 & 25 & 25 \\
\hline Total: & 0 & & \\
\hline
\end{tabular}

Créditos Atribuídos à Dissertação: 71 